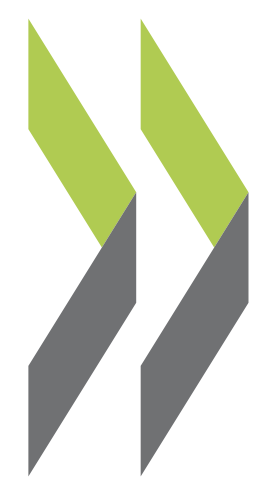

OECD Economics Department Working Papers No. 1413

\title{
Ensuring Fiscal \\ Sustainability in Japan in the Context of a Shrinking and Ageing Population
} Randall S. Jones, Kohei Fukawa 
Organisation de Coopération et de Développement Économiques

Organisation for Economic Co-operation and Development

02-Oct-2017

ECONOMICS DEPARTMENT

English - Or. English

\section{ENSURING FISCAL SUSTAINABILITY IN JAPAN IN THE CONTEXT OF A SHRINKING AND} AGING POPULATION

ECONOMICS DEPARTMENT WORKING PAPERS No. 1413

By Randall S. Jones and Kohei Fukawa

OECD Working Papers should not be reported as representing the official views of the OECD or of its member countries. The opinions expressed and arguments employed are those of the author(s).

Authorised for publication by Alvaro Pereira, Director, Country Studies Branch, Economics Department

All Economics Department Working Papers are available at www.oecd.org/eco/workingpapers.

Complete document available on OLIS in its original format

This document, as well as any data and map included herein, are without prejudice to the status of or sovereignty over any territory, to the delimitation of international frontiers and boundaries and to the name of any territory, city or area. 
OECD Working Papers should not be reported as representing the official views of the OECD or of its member countries. The opinions expressed and arguments employed are those of the author(s).

Working Papers describe preliminary results or research in progress by the author(s) and are published to stimulate discussion on a broad range of issues on which the OECD works.

Comments on Working Papers are welcomed, and may be sent to the Economics Department, OECD, 2 rue André-Pascal, 75775 Paris Cedex 16, France, or by e-mail to econ.contact@oecd.org.

All Economics Department Working Papers are available at www.oecd.org/eco/workingpapers.

This document and any map included herein are without prejudice to the status of or sovereignty over any territory, to the delimitation of international frontiers and boundaries and to the name of any territory, city or area.

The statistical data for Israel are supplied by and under the responsibility of the relevant Israeli authorities. The use of such data by the OECD is without prejudice to the status of the Golan Heights, East Jerusalem and Israeli settlements in the West Bank under the terms of international law.

You can copy, download or print OECD content for your own use, and you can include excerpts from OECD publications, databases and multimedia products in your own documents, presentations, blogs, websites and teaching materials, provided that suitable acknowledgment of OECD as source and copyright owner is given. All requests for commercial use and translation rights should be submitted to rights@oecd.org 
ECO/WKP(2017)45

\section{ABSTRACT/RÉSUMÉ \\ Ensuring fiscal sustainability in Japan in the context of a shrinking and ageing population}

With gross government debt of 219\% of GDP in 2016, Japan's fiscal situation is in uncharted territory and puts the economy at risk. In addition to raising productivity and growth, Japan needs a more detailed and credible fiscal consolidation path, including specific revenue increases and measures to control spending to restore fiscal sustainability. Spending pressures associated with rapid population ageing make reforms to contain social expenditures a priority. Local governments need to be part of the effort to contain public spending in the context of a shrinking population. Much of the consolidation, though, will have to be on the revenue side, primarily through hikes in the consumption tax rate toward the OECD average and a broadening of the personal income tax base. Fiscal consolidation should be accompanied by measures to promote inclusive growth through the tax and benefit system, in particular by introducing an earned income tax credit to assist the working poor, hiking the tax on capital income and broadening the base of the inheritance tax.

This Working Paper relates to the 2017 OECD Economic Survey of Japan (www.oecd.org/eco/surveys/economic-survey-japan.htm)

JEL classification: H2, H5, H6, H7.

Keywords: Abenomics, fiscal policy, public debt, social security, consumption tax, fiscal consolidation, fiscal sustainability, debt dynamics, fiscal management strategy, independent fiscal councils, poverty, inequality, pensions, healthcare, long-term care, EITC.

************************************

\section{Assurer la viabilité des finances publiques au Japon dans le contexte d'une population déclinante et vieillissante}

Compte tenu d'une dette publique brute égale à $219 \%$ du PIB, la situation budgétaire du Japon est inédite et menace l'économie du pays. Outre qu'il lui faut accroître sa productivité et son taux de croissance, le Japon a aussi besoin d'une trajectoire plus précise et crédible pour l'assainissement de ses finances publiques, passant par certaines augmentations de recettes et la maîtrise des dépenses publiques pour restaurer sa viabilité budgétaire. Les tensions que fait peser le vieillissement rapide de sa population rendent d'autant plus urgentes les réformes de maîtrise des dépenses sociales. Les administrations locales doivent être associées aux efforts de maitrise des dépenses publiques dans le contexte d'une démographie en baisse. Cela étant, une bonne part des efforts d'assainissement devront porter sur les recettes, essentiellement avec un relèvement du taux de la taxe sur la consommation pour le rapprocher de la moyenne de l'OCDE et un élargissement de l'assiette de l'impôt sur le revenu des personnes physiques. L'assainissement des finances publiques devrait aller de pair avec des mesures en faveur de la croissance inclusive via le système de prélèvements et de prestations, notamment avec la mise en place d'un crédit d'impôt sur le revenu d'activité pour aider les travailleurs pauvres, un relèvement de la taxe sur les revenus du capital et un élargissement de l'assiette des droits de succession.

Ce Document de travail a trait à l'Étude économique de l'OCDE du Japon, 2017

(http://www.oecd.org/fr/eco/etudes/etude-economique-japon.htm).

Classification JEL : H2, H5, H6, H7.

Mots clés : Abenomics, politique budgétaire, dette publique, sécurité sociale, impôt sur la consommation, assainissement budgétaire, viabilité budgétaire, dynamique de la dette, stratégie de gestion budgétaire, conseils budgétaires indépendants, pauvreté, inégalité, retraite, soins de santé, soins de longue durée, crédit d'impôt sur les revenus du travail. 


\section{TABLE OF CONTENTS}

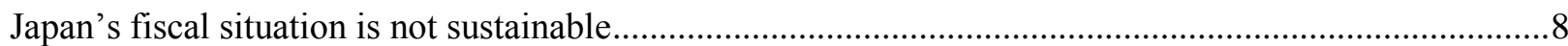

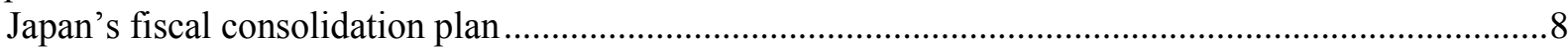

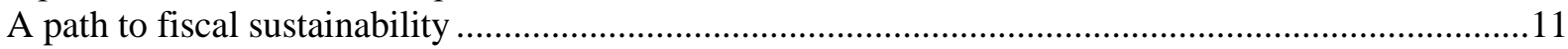

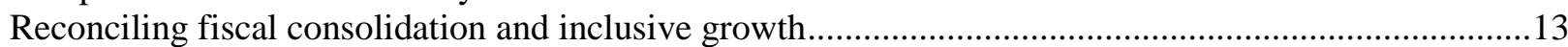

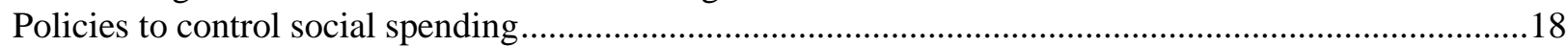

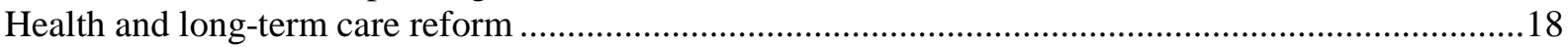

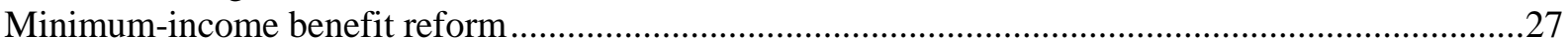

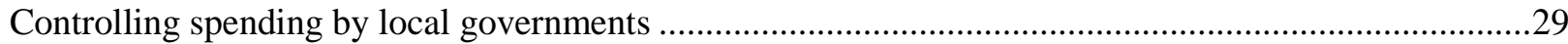

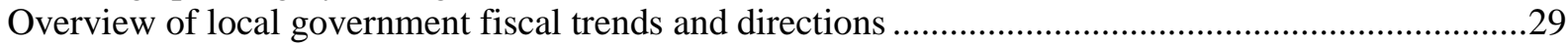

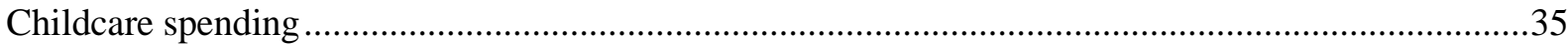

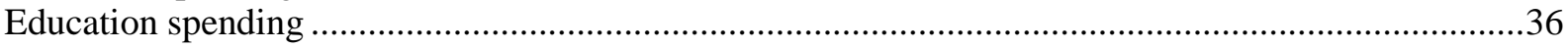

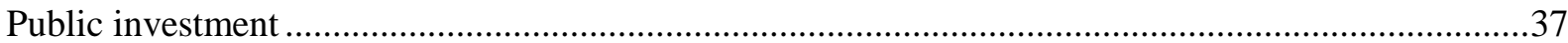

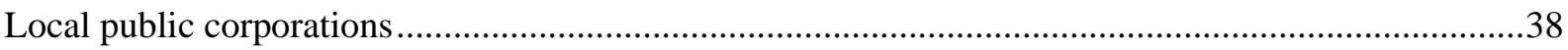

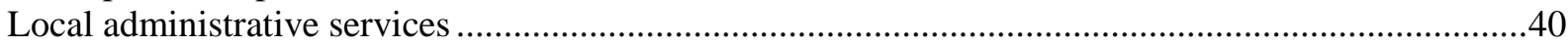

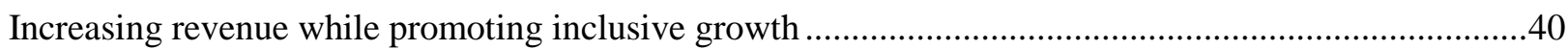

Further raise the consumption tax, while keeping a single rate ........................................................4

Reforming personal income tax and social security contributions would promote inclusive growth ....44

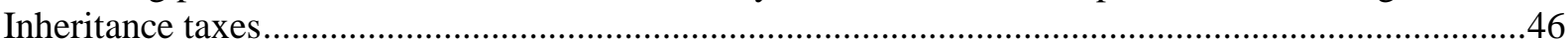

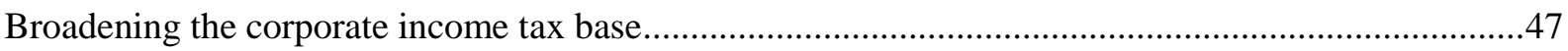

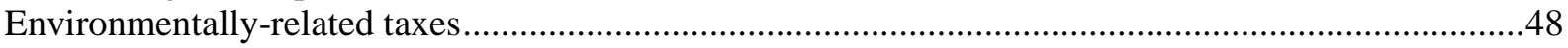

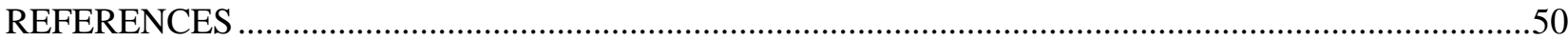

\section{Tables}

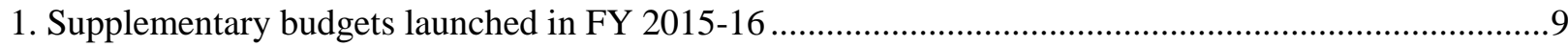

2. Fiscal assumptions to calculate the necessary size of consolidation...................................................11

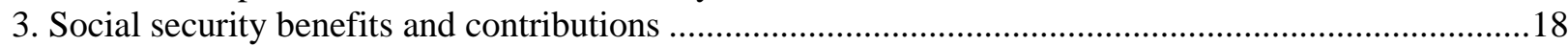

4. International comparisons show room for healthcare cost savings in Japan......................................20

5. Raising the pensionable age leads to a large increase in the replacement rate ....................................27

6 The ageing of public infrastructure poses challenges for local governments ........................................38

7. Japan's personal income tax base is subject to a range of deductions ...................................................44

\section{Figures}

1. Japan's fiscal situation has deteriorated over the past 20 years ..........................................................6

2. Rapid population ageing will create strong upward pressure on government spending in Japan ............7

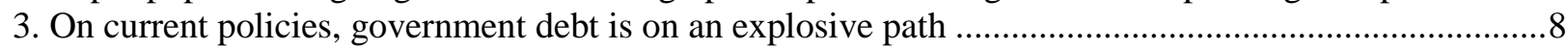

4. Government projections show it failing to meet its deficit targets .................................................... 10

5. Sustained fiscal consolidation is needed to reduce and stabilise the government debt ratio .................13

6. The impact of the social safety net on the working-age population is weak in Japan .........................14

7. The upward trend in public social spending in Japan is projected to continue....................................15

8. The tax and transfer system redistributes income from the working-age population to the elderly .......16

9. Transfers and asset holdings support high levels of consumption among the elderly ..........................17 
10. Health spending in Japan increased rapidly due to ageing and more intensive care .19

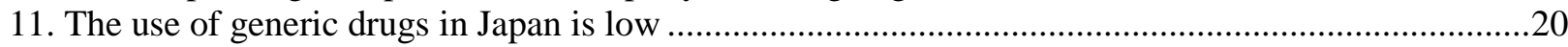

12. The elderly in Japan make frequent use of medical services ..........................................................21

13. The higher the number of beds, the longer are hospital stays, leading to greater health spending ......23

14. Long-term care expenditure has more than doubled in 14 years .......................................................24

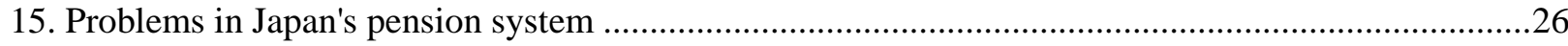

16. The coverage of the Basic Livelihood Protection Program is rising ...............................................28

17. Subnational government revenue, expenditure and debt in Japan relative to the OECD ....................30

18. Local government expenditure is steady but its composition is changing ........................................31

19. Differences in per capita spending is largely financed by central government transfers.....................32

20. Spending by municipalities is driven up by ageing and falling population density............................32

21. The decline in Yubari's population is projected to continue .............................................................33

22. Yubari is paying more than half of its general revenue for debt redemption........................................34

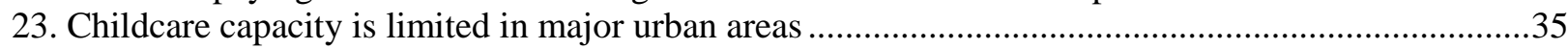

24. The fall in the number of school-age children allows scope for school consolidation ........................36

25. The public capital stock in Japan is exceptionally large ...................................................................37

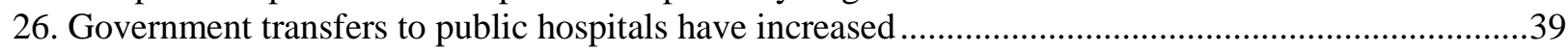

27. Japan's taxes on goods and services, and personal income are relatively low ...................................40

28. Social security contributions have risen significantly during the past 25 years..................................41

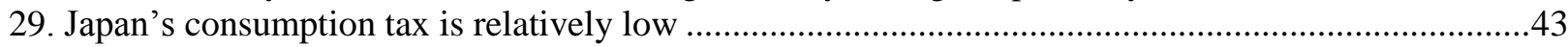

30. Replacing income deductions with a tax credit would lower the burden on low-income households. 45

31. Social security contributions pose heavy burdens on non-regular workers ......................................47

32. The effective personal income tax rate on high-earners is reduced by low rates on capital gains.......48

33. Environmentally-related taxes in Japan are well below the OECD mean .........................................48

\section{Boxes}

Box 1. Economic and Fiscal Revitalization Action Program ..........................................................10

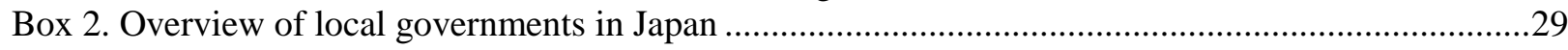

Box 3. Policies to cope with population decline and ageing..................................................................33

Box 4. Main policy recommendations to ensure fiscal sustainability in the context of a shrinking and ageing population..... 


\title{
ENSURING FISCAL SUSTAINABILITY IN JAPAN IN THE CONTEXT OF A SHRINKING AND AGEING POPULATION
}

\author{
By Randall S. Jones and Kohei Fukawal
}

Twenty-five years of budget deficits have driven up gross government debt from 68\% of GDP in 1992 to around $219 \%$ in 2016, the highest ever recorded in the OECD (Figure 1). The government does have a large stock of assets, but net debt, at $122 \%$ of GDP, is still the third highest in the OECD. Government gross debt rose 1.14 million yen (USD 10000 ) per second in 2015. The primary deficit is projected to be around 5\% of GDP in 2017, further pushing up debt. Japan's fiscal problem reflects a run-up in spending since 1990 that has not been matched by a rise in revenues (Panel B).

The impact of high debt is mitigated at present by low interest rates, in part due to large-scale government bond purchases by the Bank of Japan (BoJ) under its Quantitative and Qualitative Monetary Easing (QQE) policy launched in 2013 to achieve its 2\% inflation target. Yields are also pushed down by persistent deflationary pressures and the risk aversion and home bias of investors. Around $90 \%$ of government debt is domestically held. Nevertheless, the external debt of the government and the central bank has risen to around two-thirds of their external assets. The outlook for the government bond market once the BoJ achieves its inflation target and phases out QQE is uncertain.

\section{Figure 1. Japan's fiscal situation has deteriorated considerably over the past 20 years}

As a percentage of GDP
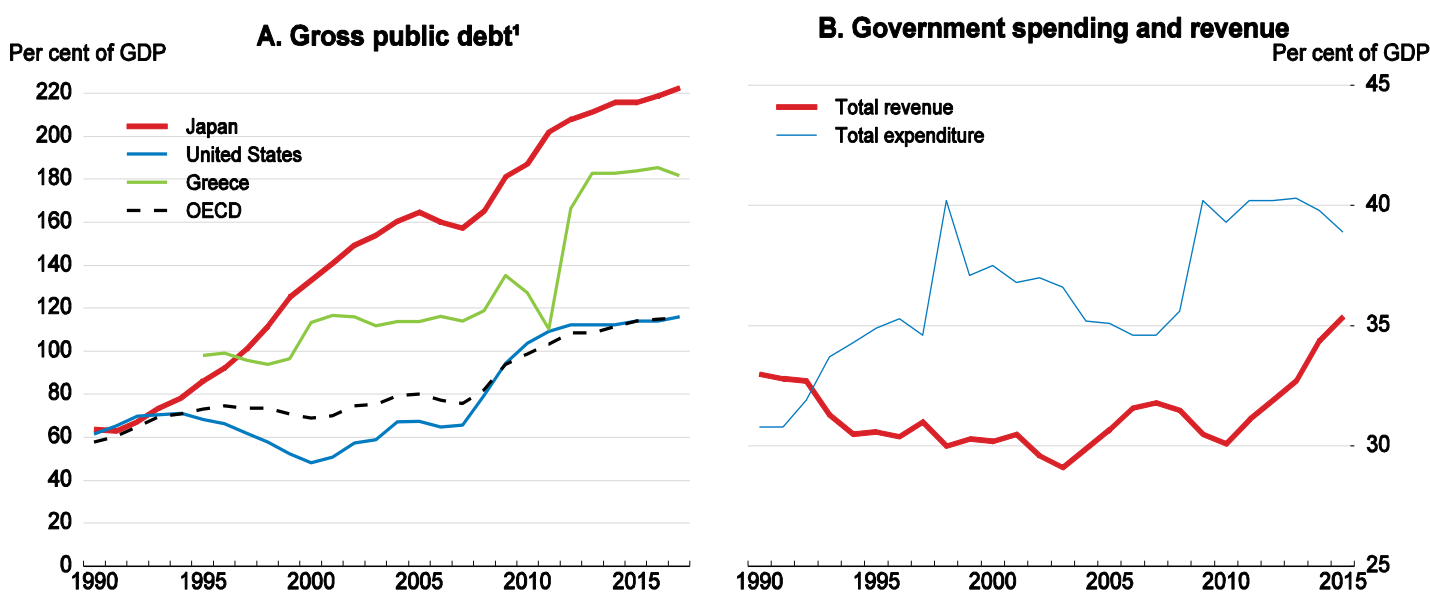

1. OECD projections for 2016-17.

Source: OECD (2017b), OECD Economic Outlook: Statistics and Projections (database).

1. Randall S. Jones is head of the Japan/Korea Desk in the Economics Department of the OECD and Kohei Fukawa was an economist on the Desk when the paper was written and now works in the Cabinet Office in the government of Japan. The authors would like to thank OECD Economics Department colleagues Robert Ford, Yvan Guillemette, Peter Hoeller, Yosuke Jin, Vincent Koen, Patrick Lenain and Alvaro Pereira, as well as Akiko Maeda, Tim Muir and Angelica Salvi del Pero (OECD Directorate for Employment and Social Affairs), Akito Konagaya and Iota Nassr (OECD Directorate for Financial and Enterprise Affairs) and Shingo Kimura (OECD Trade and Agriculture Directorate), Thomas Weko (OECD Directorate for Education and Skills), and officials from the Japanese government, for valuable comments and/or discussions. Special thanks go to Lutécia Daniel (OECD Economics Department) for technical assistance and Mercedes Burgos (previously OECD Economics Department, now the Trade and Agricultural Directorate of the OECD) and Sisse Nielsen (OECD Economics Department) for technical preparation. 
Government projections show the primary budget remaining in deficit through FY 2024. The fiscal challenge is magnified by Japan's shrinking and ageing population, which puts further upward pressure on public spending and reduces the tax base which finances that spending. The population is projected to fall by a third from 127 million in 2015 to 87 million in 2060, while the share above age 65 increases from $26 \%$ to $40 \%$ (Figure 2). Japan's elderly population will rise from $44 \%$ of the $15-64$ age group in 2015 to $75 \%$ in 2050 , the highest in the OECD over that time frame. Moreover, the elderly population is getting older: the share of the population over age 75 - when the costs of health and long-term care rise sharply will reach $27 \%$ in 2060. The proportion of persons over age 65 who live alone is expected to surpass $20 \%$ by 2035. Age-related expenditure by the government is projected to rise by 6-7 percentage points of GDP over 2020-60, significantly more than in major European countries that also face rapid population ageing (Panel B).

Figure 2. Rapid population ageing will create strong upward pressure on government spending in Japan

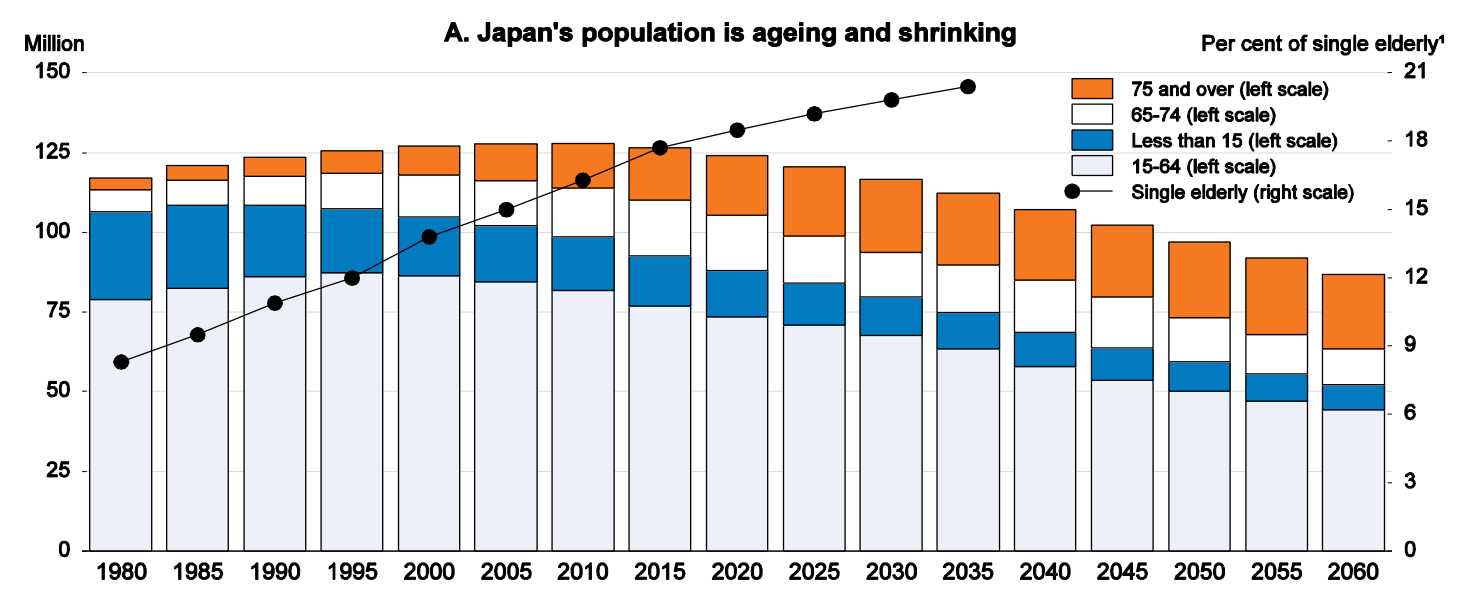

B. The Increase In public agelng-related spending Is projected to be relatlvely large In Japan

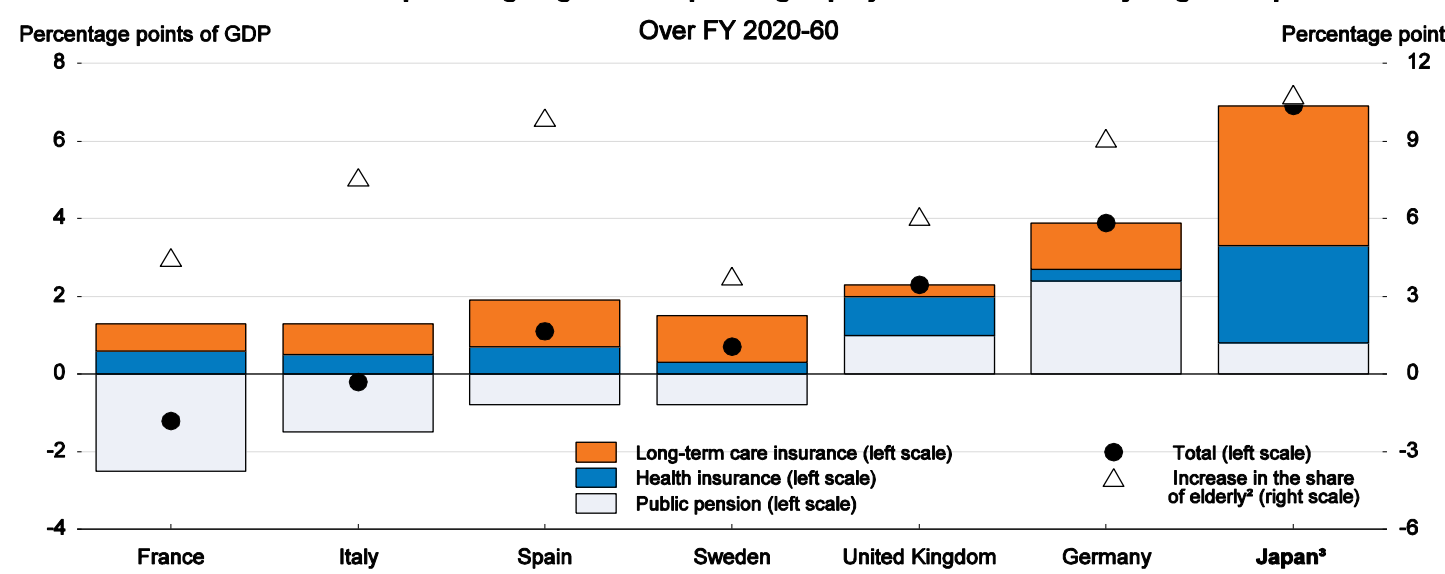

1. Share of the population aged 65 or over living alone as a percentage of the total population aged 65 or over.

2. Increase in the share of the population over age 65.

3. Medical assistance in the Basic Livelihood Protection Program is included in health insurance. Public pension spending in Japan is based on case C of the actuarial valuation by Ministry of Health, Labor and Welfare (2014).

Source: OECD (2015a); Cabinet Office (2014a); Fiscal System Council (2015); European Commission (2015).

After an overview of Japan's fiscal predicament, this paper reviews options to restore fiscal sustainability. Policies to limit the growth of public social expenditures are discussed in the second section, while the following section focuses on local government. Measures to increase revenue are discussed in the fourth section. Policy recommendations are summarised in Box 4. 


\section{Japan's fiscal situation is not sustainable}

A simulation by the Fiscal System Council presents two alternative scenarios. Both assume that a small primary surplus (central and local governments) is achieved by FY 2020 and that government revenue and spending that is not related to ageing remain constant as a share of GDP over FY 2020-60. Age-related spending is projected to increase from $24 \%$ to $31 \%$ of GDP over FY 2020-60, based on per capita benefit levels by age, taking changes in the population structure into account. In the first scenario, a primary surplus is followed by a fiscal consolidation of 93/4 per cent of GDP in FY 2020, reducing the government debt ratio to 105\% of GDP in FY 2060 (Figure 3). In the second scenario, there is no fiscal consolidation over FY 2020-60, leading to a sharp increase in the debt ratio. This reaffirms the necessity of significant fiscal consolidation to ensure fiscal sustainability.

\section{Figure 3. Long-run simulations of the government debt ratio}

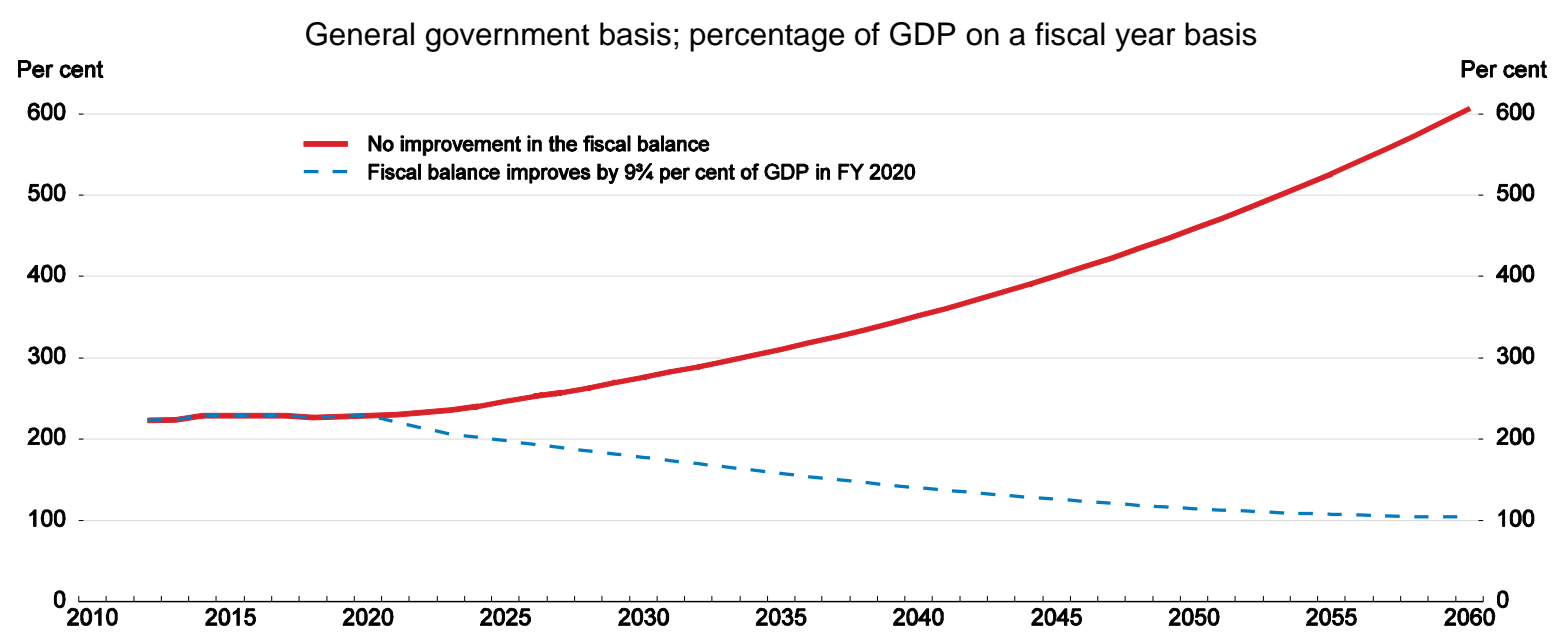

Note: The economic assumptions for nominal and real growth and the long-term interest rate through FY 2024 are based on the "economic revitalization scenario" in the "Economic and Fiscal Projections for Medium to Long-term Analysis" by the Cabinet Office (July 2015 version). After FY 2024, assumptions are based on one of the cases in the "Actuarial Valuation of Employees' Pension Insurance and the National Pension in FY 2014" by the Ministry of Health, Labor and Welfare. The simulation is based on SNA 1993.

Source: Fiscal System Council (2015).

\section{Japan's fiscal consolidation plan}

In 2015, the government adopted a fiscal consolidation plan that included targets that are broadly in line with the strategy laid out in 2010: a primary surplus for central and local governments by FY 2020 and a steady reduction in the government debt to GDP ratio thereafter. The plan, which was reaffirmed in the 2016 Basic Policies for Economic and Fiscal Management and Reform, also included:

- Capping the nominal increase in expenditure at 1.6 trillion yen (0.3\% of GDP) over FY 2015-18, taking into account economic and price developments.

- Containing the growth of social security spending resulting from ageing and the enhancement of social security programmes financed by the second consumption tax hike.

- Requiring local governments to pursue fiscal consolidation in tandem with the central government.

- A primary deficit of 1\% of GDP in FY 2018 was set as a benchmark to reach the FY 2020 target.

However, the spending restraint in initial budgets has been undermined by supplementary budgets amounting to a total of 9.2 trillion yen in FY 2015-16 (1.8\% of GDP) (Table 1). Partly as a result, the government's January 2017 projection shows the primary deficit (central and local governments) widening 
from 3.0\% of GDP in FY 2015 to 3.7\% in FY 2016 before falling slightly in FY 2017 (Figure 4). In contrast, the previous projection (July 2016) showed the primary deficit narrowing to $2.2 \%$ of GDP in FY 2017, more than $1 \%$ of GDP less than the latest projection. In FY 2018, the projected deficit of $2.4 \%$ of GDP is well above the $1 \%$ benchmark. About half of the shortfall is due to the decision to delay the consumption tax hike planned for April 2017.

Table 1. Supplementary budgets launched in FY 2015-16

General account spending in trillion yen

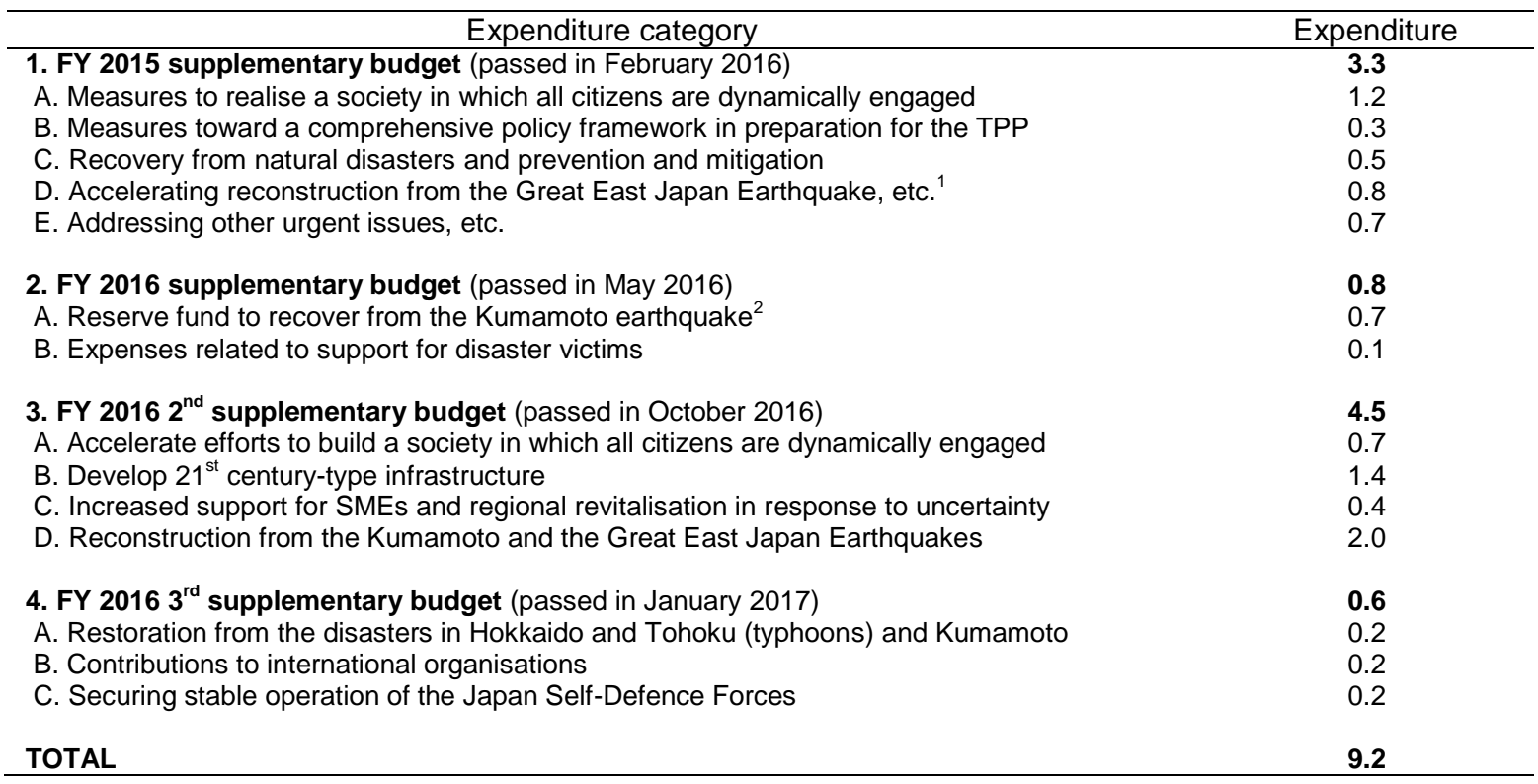

1. This category was reduced by 0.2 trillion yen in the FY 2016 supplementary budget.

2. The expense was reduced by 0.4 trillion yen in the FY 2016 2nd supplementary budget.

Source: Ministry of Finance.

The government projects (Figure 4) a primary deficit of 1.4\% of GDP in FY 2020 (central and local governments) even under some favourable assumptions: $i$ ) nominal GDP grows by $3.2 \%$ a year on average over FY 2017-20 (the "economic revitalization scenario"); ii) the consumption tax is hiked to $10 \%$ in 2019; iii) primary spending, excluding social security, is constant in real terms after FY 2018; and iv) social security spending growth is determined by a number of factors, such as population ageing, inflation and wage growth from FY 2018 onward (Cabinet Office, 2017). Under the baseline case, with annual nominal GDP growth of $2.0 \%$, the government projects that the primary deficit would increase from $1.9 \%$ of GDP in FY 2020 to $2.5 \%$ in FY 2025, demonstrating the importance of economic growth for fiscal consolidation. 
Figure 4. Government projections show it failing to meet its fiscal targets

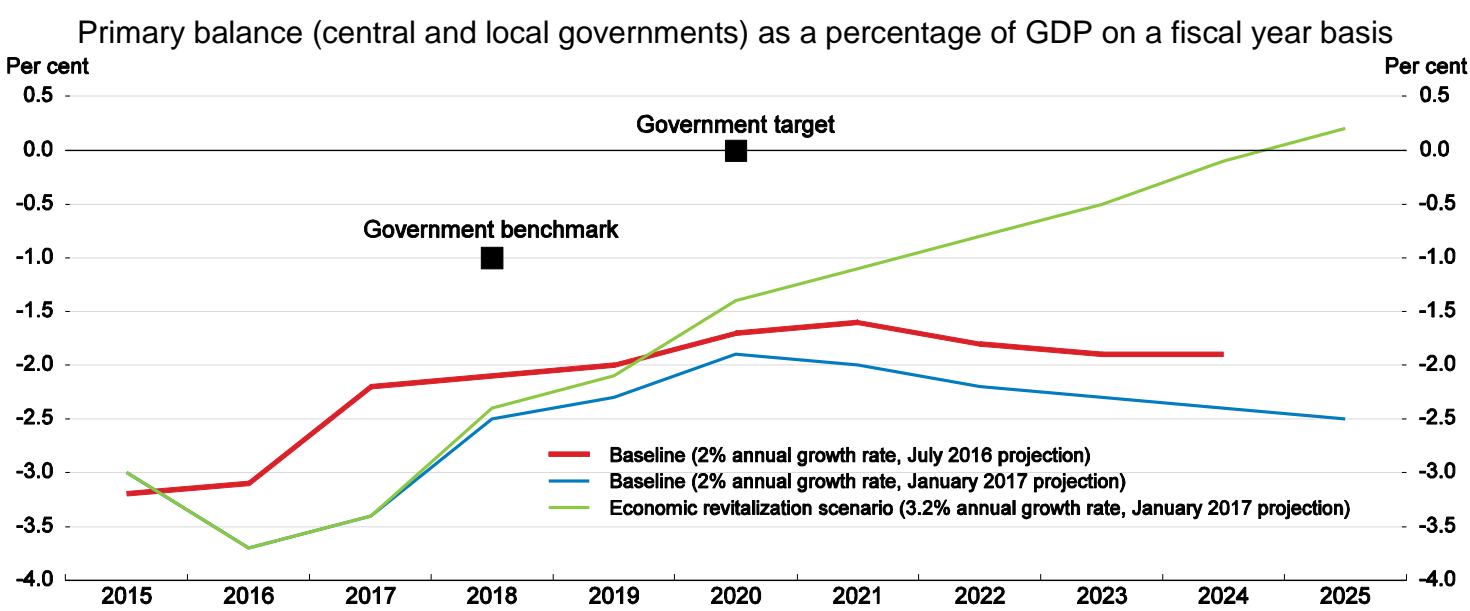

Note: The 2018 benchmark will be reviewed and addressed in light of the postponement of the consumption tax hike.

Source: Cabinet Office (2016c and 2017).

The Council on Economic and Fiscal Policy (CEFP) announced in 2015 the Economic and Fiscal Revitalization Action Program, which was updated in December 2016. The Program includes 80 reforms to limit spending in most areas (Box 1). The expert members of the CEFP expect the Program to cut spending by more than 4 trillion yen (0.8\% of GDP) in FY 2020 (Expert Members of the Council on Economic and Fiscal Policy, 2016). Such a reduction would bring the primary deficit to less than $1 \%$ of GDP in FY 2020 under the "economic revitalization scenario".

\section{Box 1. Economic and Fiscal Revitalization Action Program}

\section{Social security reform}

- Provide transparency about regional differences in inputs and benefit levels of health and long-term care and introduce policies to reduce such differences.

- Develop regional medical plans by the end of FY 2016 to promote clinical specialisation and collaboration and reduce regional differences, for example in the number of long-term care beds.

- Establish a framework with incentives that encourage individuals and insurers to make efforts to prevent disease, reduce the need for long-term care, increase the use of generic drugs and ensure appropriate treatments.

- Ensure that the burden on individuals is in accordance with their ability to pay and set benefit levels according to their income and assets.

\section{Public investment}

- Develop compact urban structures and optimise the public capital stock by making "location optimization plans" and "comprehensive plans for public facility management" to visualise maintenance costs and the appropriate level of public capital.

- Move ahead aggressively with public-private partnerships and private-finance initiatives.

- Concentrate government investment in projects that enhance growth, the quality of life, and resilience against national disasters, while effectively containing maintenance costs under plans to extend the life of infrastructure.

\section{Local government administration}

- Compare per capita administrative cost by municipality, enhance information on fixed assets and monitor changes each year, aiming at encouraging public service reform. 
- Introduce the "Top Runner" method to base the local allocation tax (LAT) - a transfer from central to local governments - on the level of costs in local governments that carry out administrative reforms, such as outsourcing work to the private sector.

- Make a mid-term outlook for the number of school teachers, taking into account factors, such as the declining number of children, the challenges faced by schools, results of empirical research and the policy goals of local governments.

\section{A path to fiscal sustainability}

The government's consolidation plan aims to put the government debt ratio on a downward trend from FY 2021. The size of the general government primary surplus necessary to stabilise the debt ratio equals the level of debt multiplied by the gap between the nominal interest rate and nominal growth rate. If the gap were to match its average since 1980, Japan would need a primary surplus of around $2.5 \%$ of GDP (Table 2). With a primary deficit of $5 \%$ in 2017 , the fiscal consolidation necessary to achieve a $2.5 \%$ primary surplus is around $71 / 2$ per cent of GDP.

Table 2. Fiscal assumptions to calculate the required amount of consolidation

Improvement in the general government primary balance to stabilise the debt ratio (as a percentage of GDP)

\begin{tabular}{|c|c|c|c|c|c|}
\hline Years & $\begin{array}{c}\text { Average } \\
(r-g)^{1}\end{array}$ & $\begin{array}{c}\text { Gross } \\
\text { government } \\
\text { debt ratio }^{2}\end{array}$ & $\begin{array}{c}\text { Primary } \\
\text { balance } \\
\text { target }^{3}\end{array}$ & $\begin{array}{c}2017 \text { primary } \\
\text { deficit }\end{array}$ & $\begin{array}{l}\text { Total required } \\
\text { consolidation }^{4}\end{array}$ \\
\hline $1980-2015$ & 1.2 & \multirow{4}{*}{215.8} & 2.5 & \multirow{4}{*}{-5.0} & 7.5 \\
\hline $1992-2015$ & 1.7 & & 3.8 & & 8.8 \\
\hline $1992-2002$ & 2.8 & & 6.1 & & 11.1 \\
\hline 2003-2015 & 0.8 & & 1.7 & & 6.7 \\
\hline Years & $\begin{array}{l}\text { Average } \\
(r-g)^{5}\end{array}$ & $\begin{array}{c}\text { Net } \\
\text { government } \\
\text { debt ratio }\end{array}$ & $\begin{array}{c}\text { Primary } \\
\text { balance } \\
\text { target }^{3}\end{array}$ & $\begin{array}{l}2017 \text { primary } \\
\text { deficit }\end{array}$ & $\begin{array}{l}\text { Total required } \\
\text { consolidation }^{4}\end{array}$ \\
\hline $1980-2015$ & 2.1 & \multirow{4}{*}{118.4} & 2.5 & \multirow{4}{*}{-5.0} & 7.5 \\
\hline $1992-2015$ & 2.0 & & 2.4 & & 7.4 \\
\hline $1992-2002$ & 4.1 & & 4.9 & & 9.9 \\
\hline 2003-2015 & 0.2 & & 0.2 & & 5.2 \\
\hline
\end{tabular}

1. The average interest rate paid on gross government debt minus the nominal growth rate.

2. In 2015, the last year for which data are available.

3. The average $(\mathrm{r}-\mathrm{g})$ times the government debt ratio.

4. The primary balance target minus the 2017 primary deficit.

5. The average interest rate paid on net government debt minus the nominal growth rate.

Source: Calculations based on OECD (2017b), OECD Economic Outlook: Statistics and Projections (database).

The experience of 2014 suggests that the pace of consolidation should be gradual. Following the consumption tax hike from $5 \%$ to $8 \%$, the implementation of the legislated increase to $10 \%$ was postponed twice and numerous stimulus packages were introduced (Table 1). The government's primary deficit is projected to widen in 2016-17, according to OECD projections. Achieving the $7 \frac{1}{2}$ per cent of GDP in fiscal consolidation necessary to stabilise the government debt ratio over a decade would imply an annual pace of around 3/4 per cent of GDP per year. This could be achieved by: $i$ ) a gradual hike in the consumption tax rate of 1 percentage point per year, boosting revenue by $1 / 2$ per cent of GDP; ii) an additional $1 / 4$ per cent of GDP of revenue by broadening the bases of the personal and corporate income tax and the inheritance tax; and iii) freezing spending as a share of GDP, which may require spending cuts to offset increases in social spending. If spending were to rise, revenue increases would have to be larger to meet the $3 / 4$ per cent consolidation pace.

It is crucial to maintain confidence in Japan's fiscal sustainability during such an extended period of consolidation. To sustain confidence, it is essential to draw up and commit to a more detailed and credible medium-term path that contains specific spending cuts and tax increases, based on multi-year budgeting, to 
achieve the required primary surplus. Whether or not Japan's debt is sustainable depends on whether the market believes that it is sustainable: if investors buying government bonds begin to believe that they may not be paid off, then they will demand a higher rate of interest on government bonds, making the debt even less manageable.

A strong institutional framework will be needed to underpin such large-scale fiscal consolidation lasting more than a decade, which requires decisive political will and commitment, backed by public support. Such a commitment would be strengthened by improving the fiscal policy framework through a stronger legal basis for fiscal targets and expenditures (IMF, 2009), which should be anchored in a multiyear budget plan. Many OECD countries have an independent fiscal council to improve policymaking, make clear the fiscal problems and help build public consensus for consolidation (OECD, 2012). Such an approach may benefit Japan as well, alongside a strengthening of the Council on Economic and Fiscal Policy.

As noted above, the government aims at putting the government debt ratio on a downward trend from FY 2021, which would require continuing fiscal consolidation even after reaching the $2 \frac{1}{2}$ per cent of GDP primary surplus. The simulation below shows the path of the primary balance necessary to stabilise gross debt at $170 \%$ of GDP (Figure 5). Given the government's large stock of financial assets, this implies that net debt stabilises at $72 \%$ of GDP, the current OECD average. The simulation assumes continued consolidation at the $3 / 4$ per cent of GDP per year pace for various levels of the interest rate minus the nominal growth rate $(\mathrm{r}-\mathrm{g})$.

While these simulations are purely illustrative, the message is clear: stabilising the government debt ratio at a level close to the current OECD average requires decades of consolidation with primary surpluses of $10 \%$ of GDP or even higher:

- $\quad(\mathrm{r}-\mathrm{g})$ at its long-term average of around $1 \%$ (for gross debt): this could result from an interest rate of $3 \%$ while nominal growth remains at the $2 \%$ rate of 2012-16. In this case, the primary surplus would peak at 10\% in 2037 to reduce gross debt to 170\% of GDP by 2048.

- $\quad(\mathrm{r}-\mathrm{g})$ at $-0.5 \%$ : this could be achieved by effective use of the third arrow to boost nominal growth above the interest rate. In this case, the primary surplus would peak at less than 5\% in 2031, stabilising gross debt at $170 \%$ in 2042.

- An (r-g) of $2 \%$ : this could result from a rise in the risk premium, leading to an interest rate of $4 \%$, while nominal growth remains at $2 \%$. In this case, the primary surplus would peak at $14.5 \%$ of GDP in 2043, stabilising debt in 2054.

Faster output growth would reduce the size of fiscal consolidation necessary, while higher interest rates would increase it. A slower pace of consolidation at $1 / 2$ per cent per year would require a longer period of consolidation and take longer to stabilise the debt ratio (Panel B). 
ECO/WKP(2017)45

Figure 5. Sustained fiscal consolidation is needed to reduce the government debt ratio The consolidation path is shown for different values of $(r-g)^{1}$

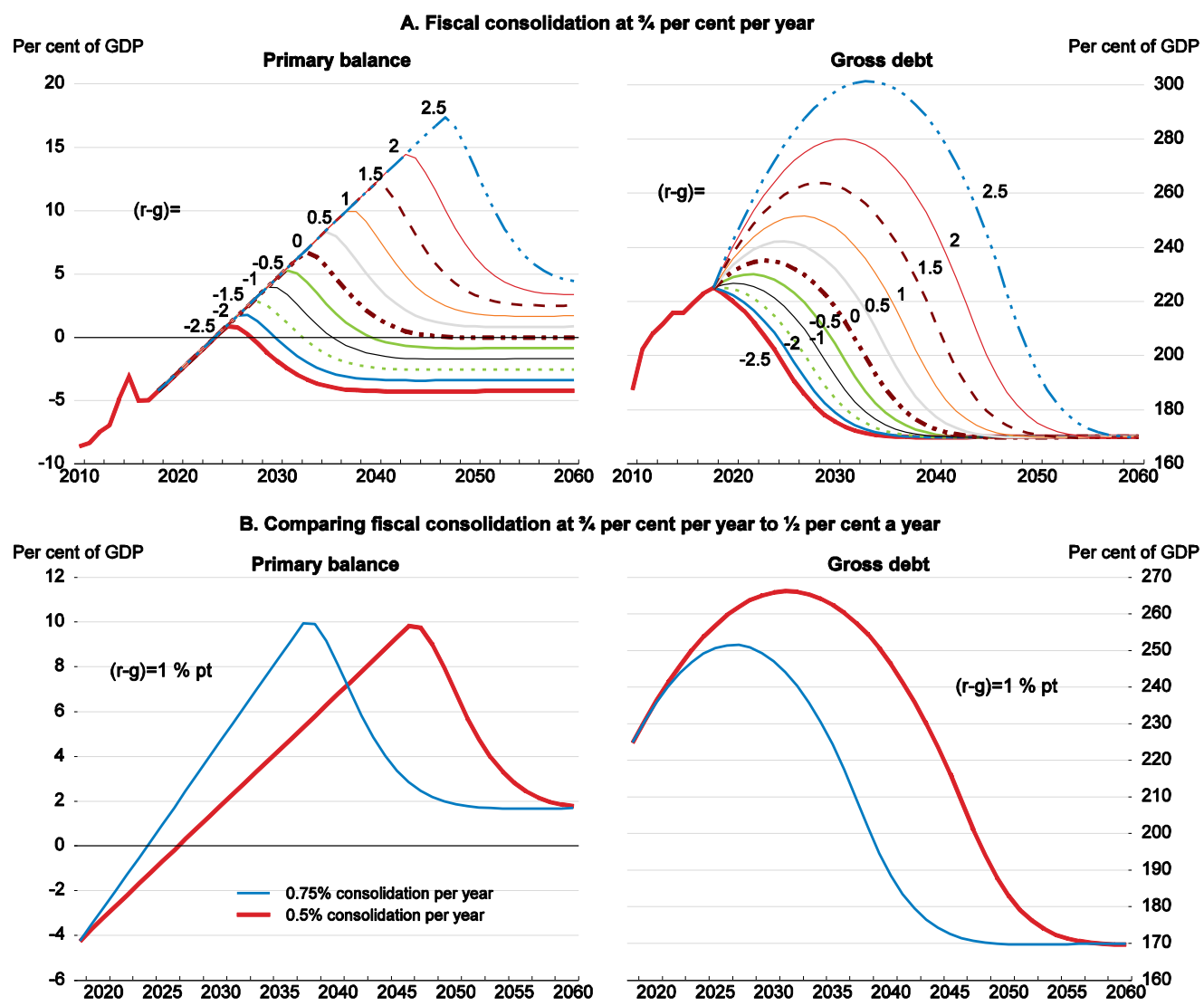

1. A fiscal multiplier of -0.5 is associated with fiscal consolidation in the simulation. This is consistent with Hamada et al. (2015), who estimate a multiplier for hikes in the consumption tax and the personal income tax of around -0.3 to -0.5 . Source: OECD calculations.

\section{Reconciling fiscal consolidation and inclusive growth}

Japan's fiscal consolidation strategy needs to take into account the importance of inclusive growth, given rising income inequality and relative poverty (2017 OECD Economic Survey of Japan). The impact of Japan's tax and benefit system on income inequality and relative poverty for the working-age population is weaker than the OECD average (Figure 6), reflecting the fact that it primarily redistributes income between rather than within generations. Indeed, social spending's impact on the Gini coefficient is significant only among the elderly (2015 OECD Economic Survey of Japan). The share of social spending allocated to programmes focused on the elderly - pensions, health and long-term care - is more than fourfifths, the second highest in the OECD in 2014. 
Figure 6. The impact of the social safety net on the working-age population is weak in Japan In 2014 or latest year available

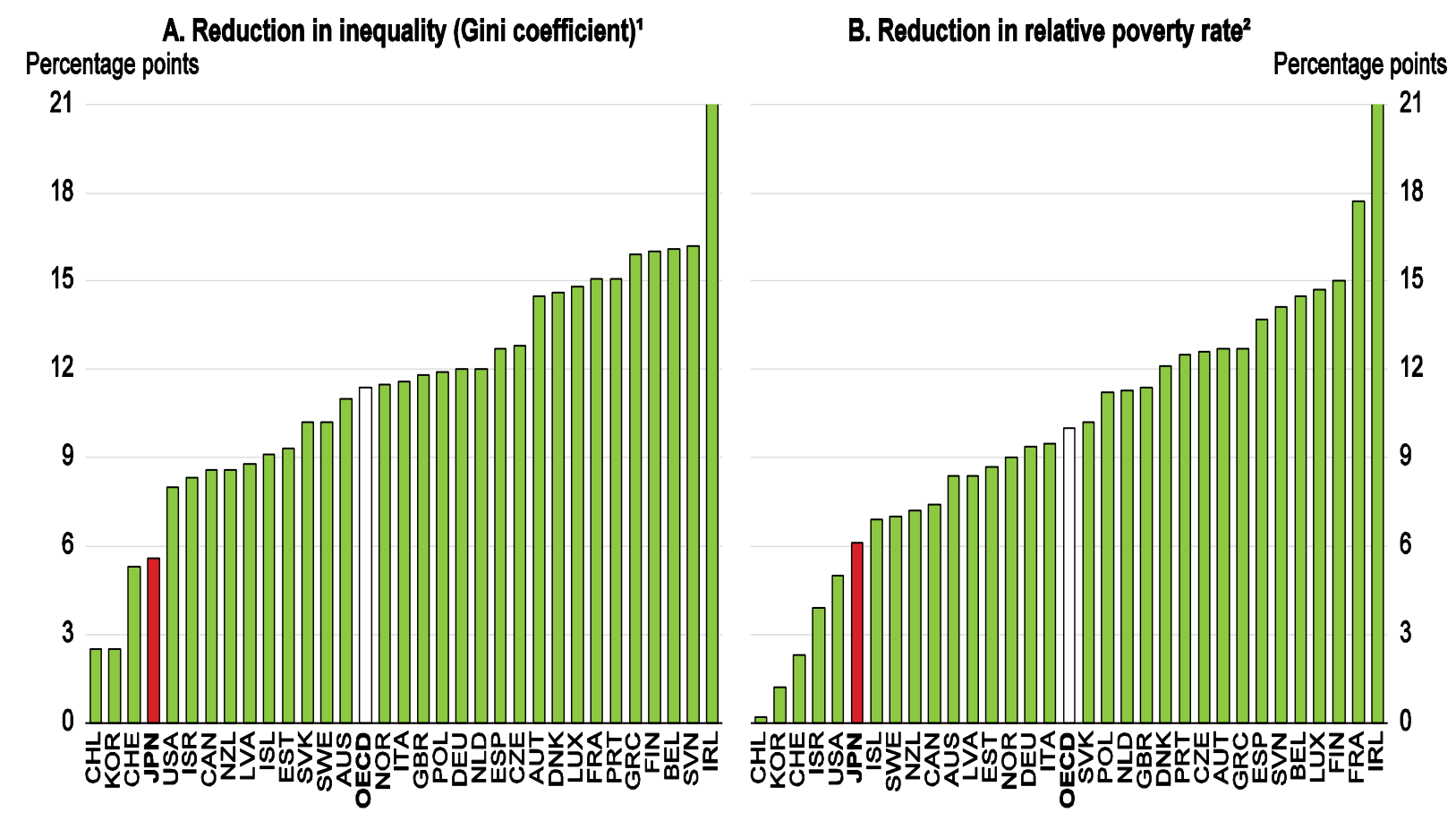

1. For the working-age population. The Gini index has a range from zero (when everybody has identical incomes) to 100 (when all income goes to only one person). Increasing values of the Gini coefficient thus indicate higher inequality in the distribution of income.

2. For the working-age population. The relative poverty rate is the percentage of households whose income is less than half of the median income.

Source: OECD (2017e), OECD Income Distribution (database).

Social spending rose from $11 \%$ of GDP in 1990 to $23 \%$ in 2014, surpassing the OECD average, while tax revenue has not kept pace (Figure 7). Consequently, much of the rise in social spending was financed by borrowing, pushing up government debt. Aligning social spending and the tax burden requires limiting social spending and hiking revenue, particularly as ageing-related spending is projected to rise by $7 \%$ of GDP - from 20\% of GDP in 2020 to $27 \%$ in 2060 - under the current framework (Panel B). 
Figure 7. The upward trend in public social spending in Japan is projected to continue A. Public social spending

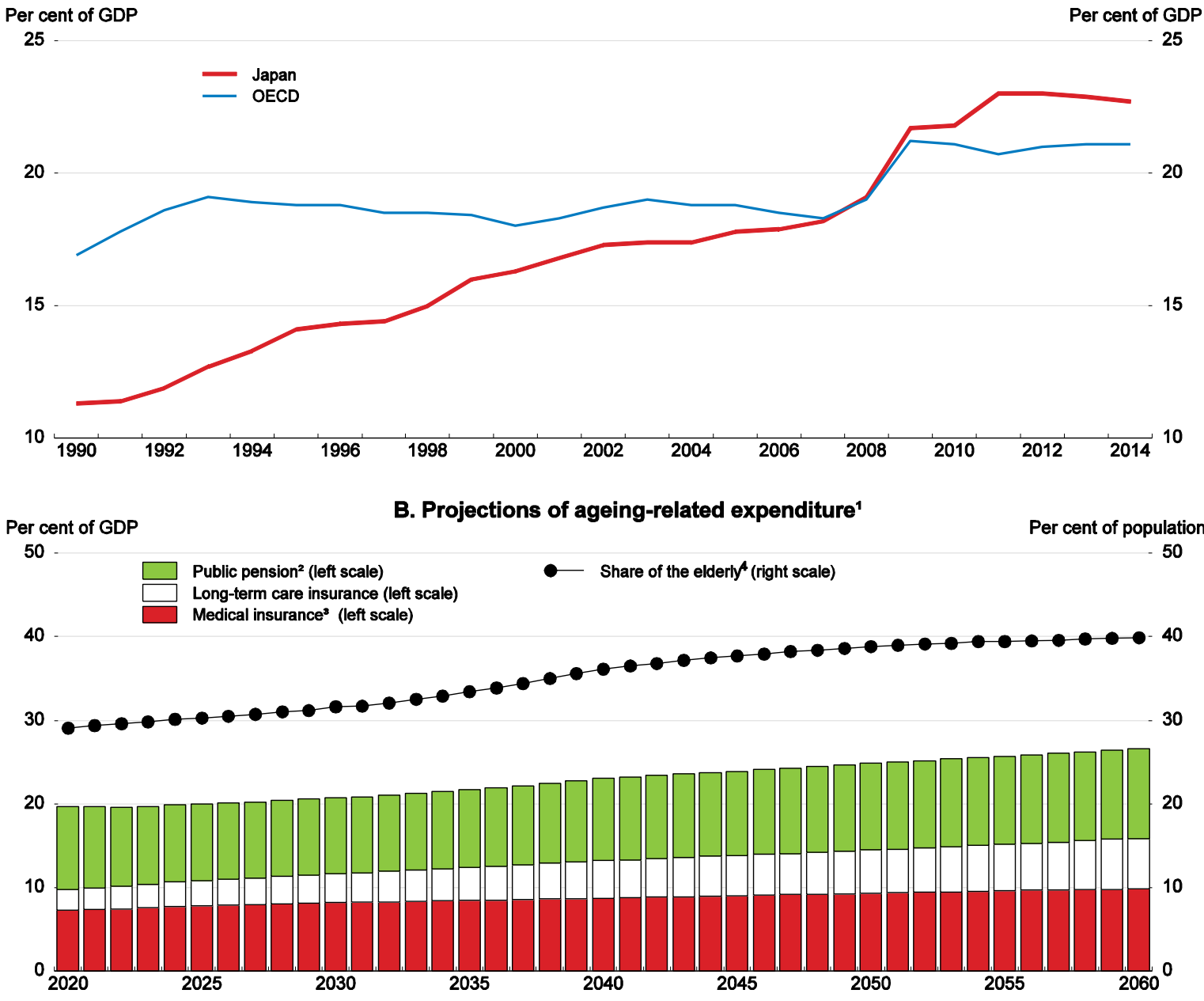

1. Fiscal System Council estimates based on the current framework, following the method of the European Commission (2012). Ageing-related spending is defined as programmes where per capita expenditure differs by age, such as pensions.

2. Public pension spending is based on the actuarial valuation by the Ministry of Health, Labor and Welfare (2014), Case C.

3. Medical assistance in the Basic Livelihood Protection Program is included in "medical insurance".

4. The population over age 65 as a share of the total population.

Source: OECD (2017f), OECD Social Expenditure Statistics (database); Fiscal System Council (2015).

Transfers from the working-age population to the elderly are substantial, raising questions of intergenerational fairness. Net average transfers to households with a person aged 60 and over were 1.9 million yen (USD 16 700) in 2009 (Figure 8), amounting to more than $40 \%$ of their disposable income. For households headed by a person under age 60 , net transfers were negative, amounting to 1.1 million, $18 \%$ of their disposable income. The burden was heaviest for households headed by a worker under 30 . Over 1994-2009, the tax and social security burden as a share of disposable income rose, particularly among the working-age population (Panel B, left-hand side). Meanwhile, social security benefits increased significantly for the population aged 65 and over (Panel B, right-hand side).

The transfers result in a high level of inter-generational inequality: a person born in 1940 receives $16.4 \%$ of lifetime earnings in net transfers, while one born in 2010 pays 12\% (Figure 8, Panel C). In terms of inter-generational justice, Japan is estimated to be the second worst among 29 OECD countries 
(Bertelsmann Stiftung, 2013). Given Japan's fiscal situation, it will be difficult to continue increasing, or even to maintain, the current level of inter-generational transfers.

Figure 8. The tax and transfer system redistributes income from the working-age population to the elderly

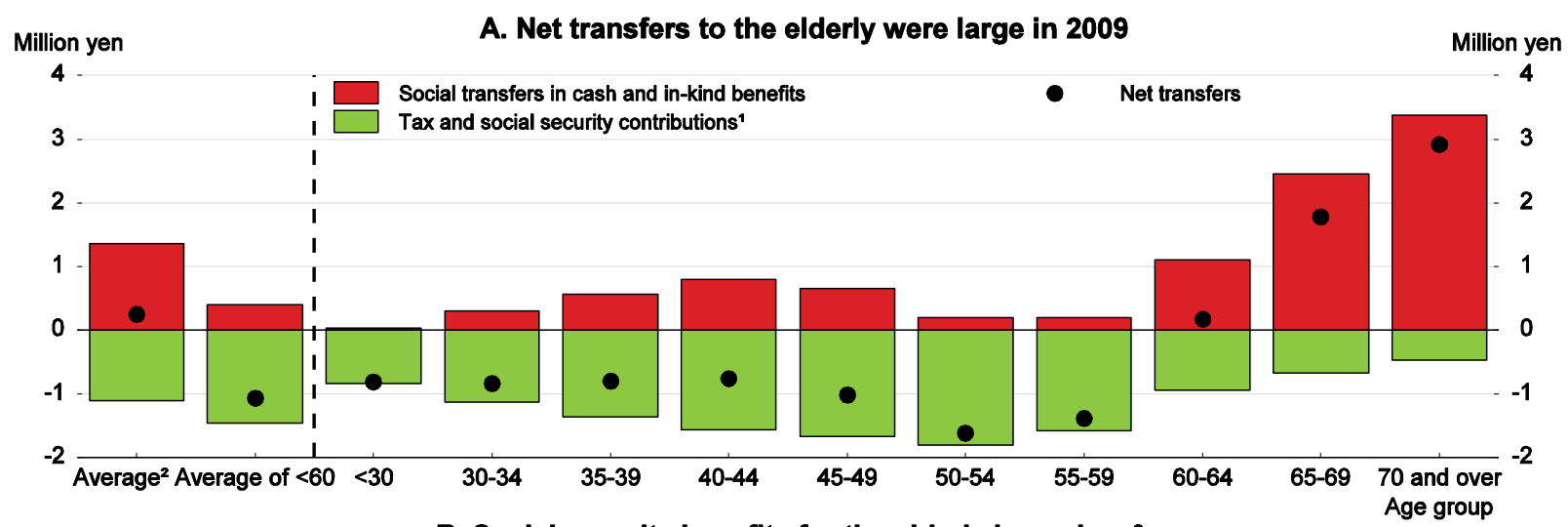

B. Social security benefits for the elderly have risen ${ }^{3}$
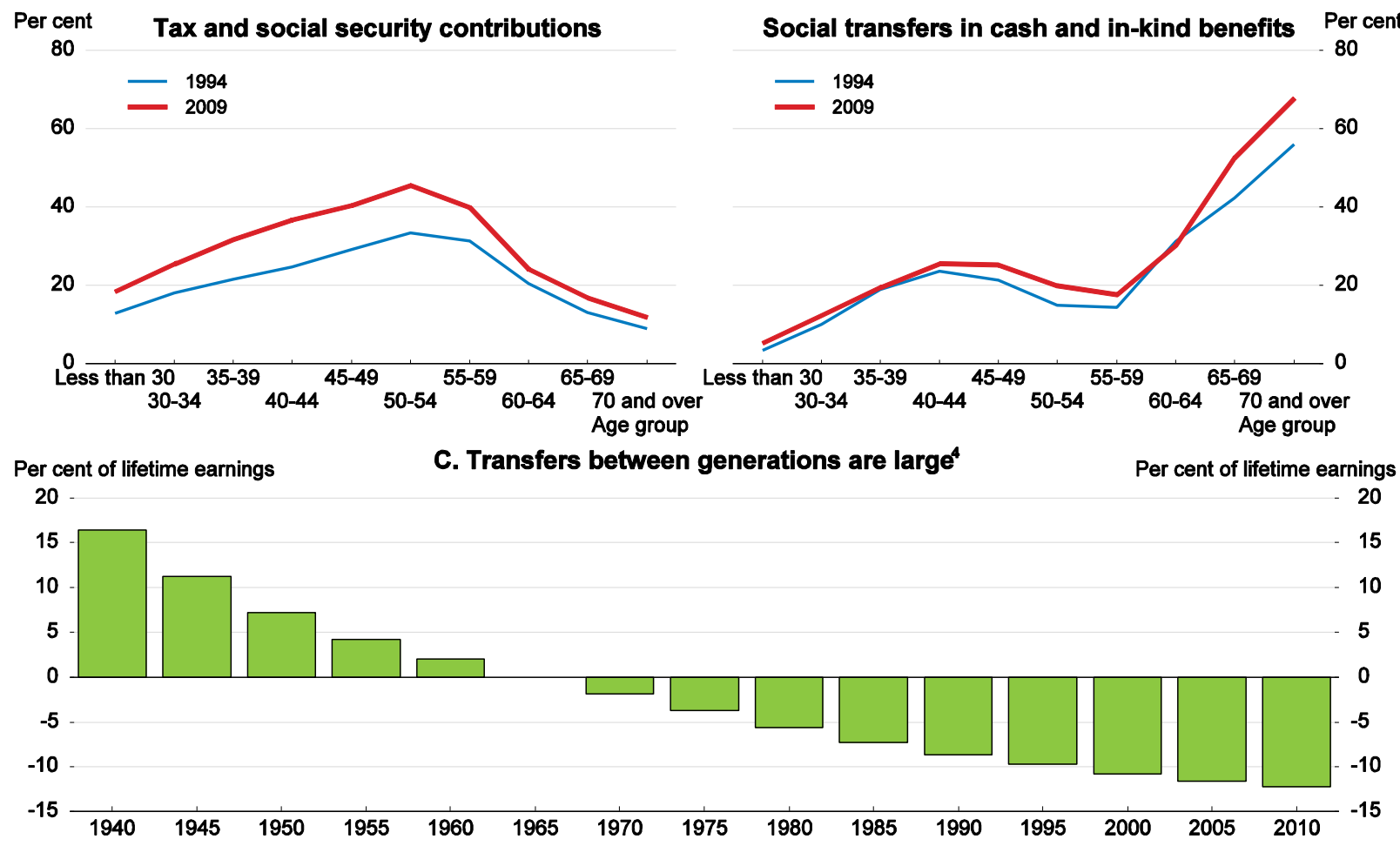

1. Includes the consumption tax

2. For the total population.

3. As a percentage of average household disposable income.

4. For men covered by employee pension and health insurance and with a non-working wife. Employees' Pension Insurance premiums are assumed to rise steadily from $18.3 \%$ in FY 2017 to $23.8 \%$ in FY 2032, and to stabilise at that level. Other assumptions include: i) an investment yield of $2.5 \%$ : ii) $2 \%$ wage growth; iii) $1 \%$ inflation, and iv) lifetime wages of workers equal to 300 million yen.

Source: Hamada (2003 and 2012); Maeda and Umeda (2013), Suzuki (2014).

The large transfers significantly increase the income of the elderly. For a household with someone aged 60 or over, disposable income was $95 \%$ of that for the under 60 age group (after adjusting for household size) in 2009 (Figure 9). Older persons have relatively large assets: in households with a person 
age 60+, assets are nearly ten times the average household disposable income for the entire population, compared to only 4.3 times for households headed by a person under age 60 (Panel B). Large social transfers and accumulated assets boost consumption by the elderly. Including in-kind benefits provided by the government, such as health and long-term care and education, "actual final consumption" (Panel A) of a household with someone age 60+ is one-third higher than for households headed by someone below age 60. Even excluding in-kind benefits, consumption of households with someone age $60+$ is higher.

Figure 9. Transfers and asset holdings support high levels of consumption among the elderly In 2009

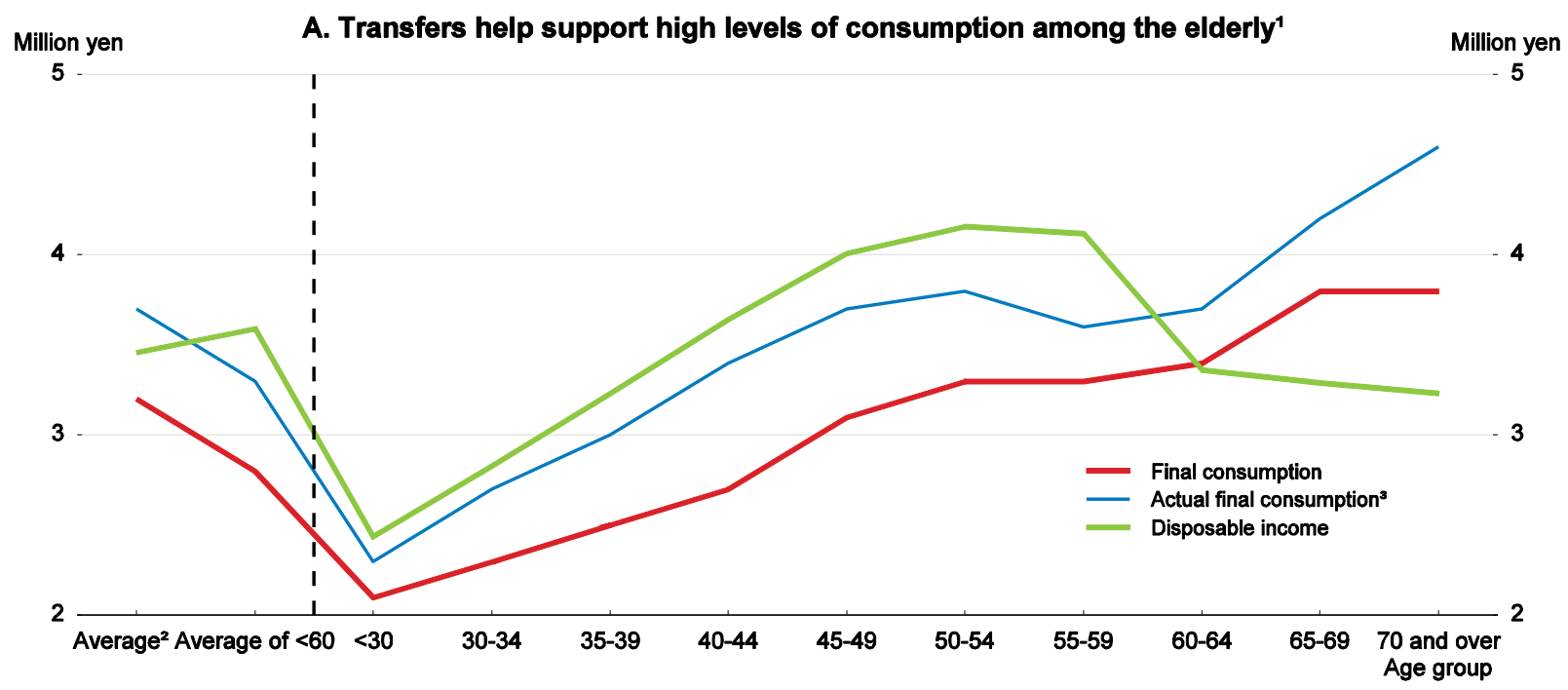

B. The elderly's net assets are nearly ten times average disposable income 4

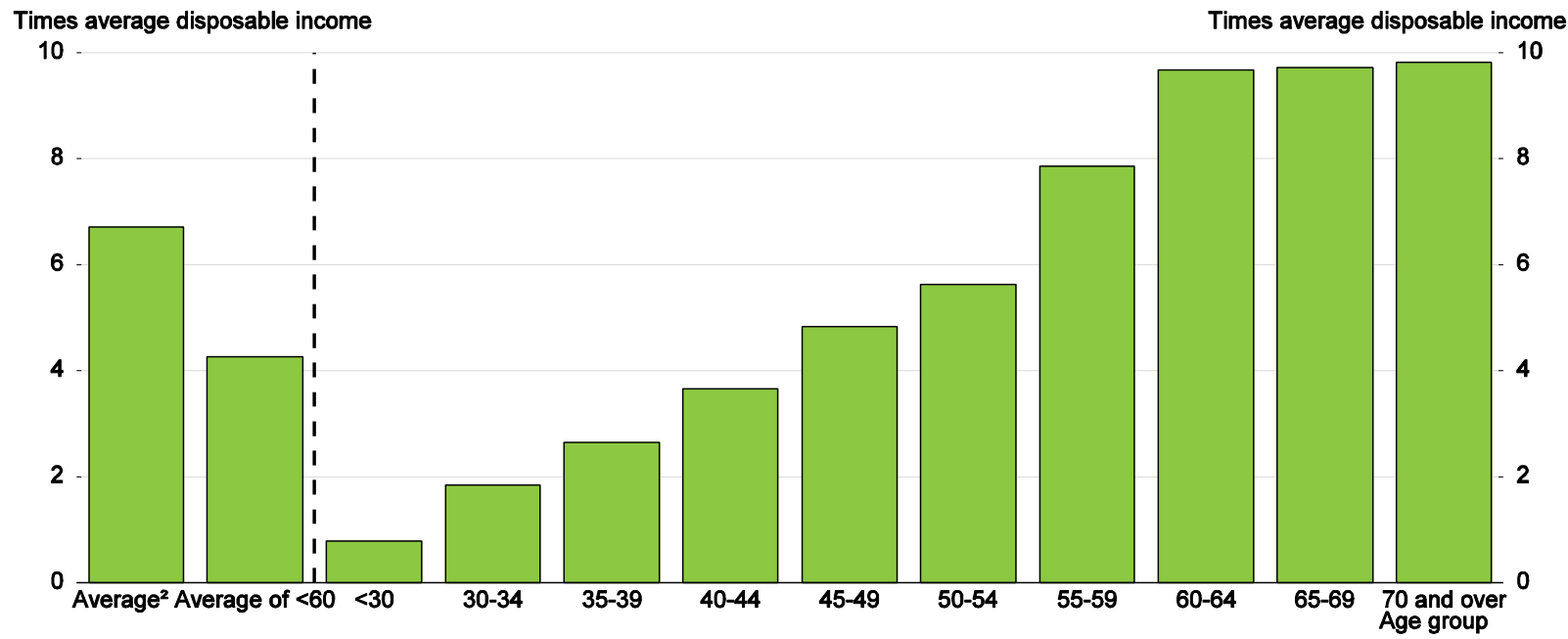

1. Data are from SNA distribution statistics. Disposable income includes depreciation of fixed capital. Consumption (both final and actual final) includes imputed rent. Each series is on an equivalised basis (the square root of household size).

2. Average of total population.

3. Includes in-kind benefits provided by the government, such as health and long-term care and education.

4. As a ratio to the average household disposable income.

Source: Hamada (2012).

Keeping Japan's promises to provide pensions and health and long-term care to its current and future elderly citizens requires achieving fiscal sustainability. At the same time, it is crucial to protect the large number of elderly living alone and in relative poverty. Achieving social inclusion also depends on the well- 
being of the working-age population. Japanese youth are the most pessimistic among 18 countries surveyed, with 37\% expecting to work until they die (Manpower Group, 2016). This pessimism is reflected in the significant fall in the number of youth contributing to the basic pension and national health insurance, even though both are legally mandatory. In a 2016 survey, only $21 \%$ of Japanese voiced optimism about the future of their country. The major reason for pessimism was a lack of effective measures to cope with the rapidly ageing and shrinking population (Geji, 2016). The following sections set out policy directions to achieve social inclusion and fiscal sustainability.

\section{Policies to control social spending}

Social security reform is the priority to control government expenditures. Spending is financed by premium payments by employees and employers and by central and local governments (Table 3). This section discusses ageing-related programmes and the Basic Livelihood Protection Program. The following section addresses programmes where local governments play an important role.

Table 3. Social security benefits and contributions

\begin{tabular}{|c|c|c|c|c|c|c|}
\hline \multirow[b]{3}{*}{ Total benefits } & \multicolumn{2}{|c|}{ FY 1990} & \multicolumn{2}{|c|}{ FY 2000} & \multicolumn{2}{|c|}{ FY 2014} \\
\hline & Trillion yen & $\%$ of GDP & Trillion yen & $\%$ of GDP & Trillion yen & $\%$ of GDP \\
\hline & 47.4 & 10.2 & 78.4 & 14.8 & 112.1 & 21.6 \\
\hline Pension & 24.0 & 5.2 & 41.2 & 7.8 & 54.3 & 10.5 \\
\hline Healthcare & 18.6 & 4.0 & 26.2 & 5.0 & 36.3 & 7.0 \\
\hline Long-term care & 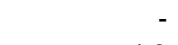 & & 3.3 & 0.6 & 9.2 & 1.8 \\
\hline Other & 4.8 & 1.0 & 7.7 & 1.5 & 12.2 & 2.4 \\
\hline Total contributions & 55.7 & 12.0 & 80.0 & 15.1 & 109.9 & 21.2 \\
\hline $\begin{array}{l}\text { Premium payments } \\
\text { Of which: }\end{array}$ & 39.5 & 8.5 & 55.0 & 10.4 & 65.1 & 12.6 \\
\hline Insured persons & 18.5 & 4.0 & 26.7 & 5.1 & 34.3 & 6.6 \\
\hline Employers & 21.0 & 4.5 & 28.3 & 5.4 & 30.9 & 6.0 \\
\hline Government & 16.2 & 3.5 & 25.1 & 4.8 & 44.8 & 8.7 \\
\hline Central & 13.5 & 2.9 & 19.7 & 3.7 & 31.8 & 6.1 \\
\hline Local $^{1}$ & 2.7 & 0.6 & 5.4 & 1.0 & 13.0 & 2.5 \\
\hline
\end{tabular}

1. Contributions by local government basically include those set by national law. Payments on the initiative of local governments only cover those related to medical benefits and operating costs for public long-term care facilities.

Source: National Institute of Population and Social Security Research (2016).

\section{Health and long-term care reform}

Healthcare spending (public and private), including long-term care, increased at a $2.7 \%$ annual rate over 2000-15, while nominal GDP was unchanged. Japan's total health spending as a share of GDP increased from 7.2\% in 2000, close to the OECD average, to 10.8\% in 2013 (Figure 10), the eighth highest. Spending in all four categories - medical goods, outpatient care, inpatient care and long-term care - is above the OECD average as a share of GDP. The upward trend in health spending is driven in almost equal measure by population ageing and rising costs per person (Panel B). These two factors were partially offset by cuts of around 3\% in medical fees in 2002 and 2006.

\section{Pharmaceuticals}

Pharmaceuticals accounted for 43\% of the rise in health spending over FY 2000-14 (Figure 10, Panel B). Japan's per capita consumption of pharmaceuticals is the second highest in the OECD at $47 \%$ above the OECD average, boosted by population ageing and the low use of generic drugs. The price at which new pharmaceuticals are reimbursed by health insurance takes into account the price and cost effectiveness of similar medicines in the package. In 2016, the government introduced the Health Technology Assessment 
to adjust the price at which pharmaceuticals are reimbursed by insurance. On the other hand, some countries, such as France, Germany and the United Kingdom, base the decision on whether to include a medicine in national health insurance coverage on its impact on patients' quality-adjusted life years. Japan's 2016 initiative should be extended to a wider range of pharmaceuticals and used to judge which pharmaceuticals should be included in public insurance coverage in the first place.

Increased use of generics is one of the measures in the Economic and Fiscal Revitalization Action Program (Box 1). Generics accounted for 34\% of the pharmaceutical market in 2015 in volume terms in Japan, below the OECD average of 50\% (Figure 11). The price of generics was reduced from $60 \%$ of that of branded drugs to $50 \%$ in 2016 . Given that the co-payment by patients is $30 \%$ ( $10 \%$ for the elderly), the price difference has not been large enough to significantly push up demand for generics. To increase the share, generics should be made the standard for reimbursement for every prescription.

Figure 10. Health spending in Japan increased rapidly due to ageing and more intensive care

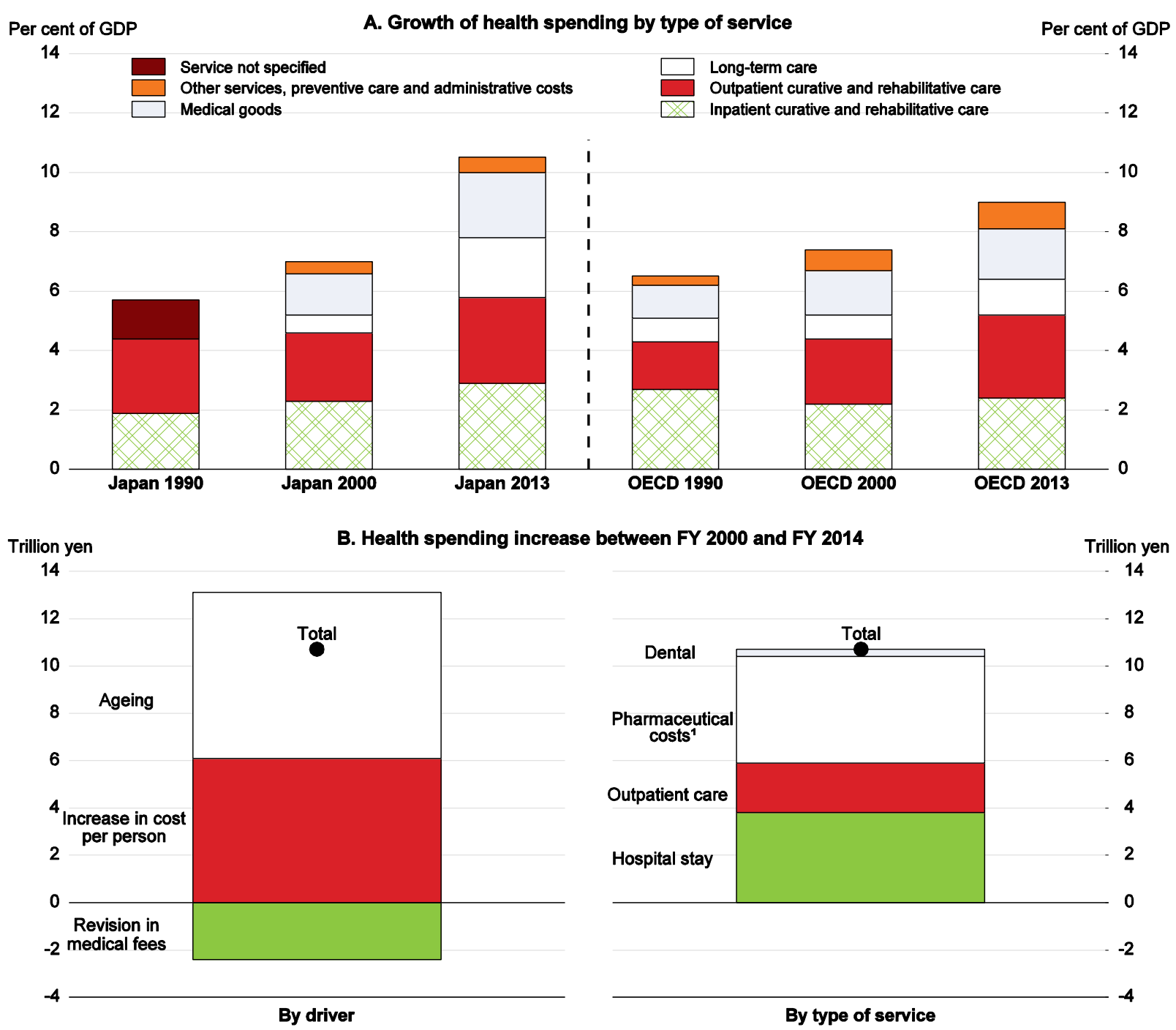

1. Includes only pharmaceuticals sold at pharmacies. Those sold elsewhere are included in the other categories.

Source: OECD (2017d), OECD Health Statistics (database); Ministry of Health, Labor and Welfare, National Health Expenditure; Ministry of Internal Affairs and Communications, Demographic Statistics; OECD calculations. 
Figure 11. The use of generic drugs in Japan is low

In 2015 or latest year ${ }^{1}$

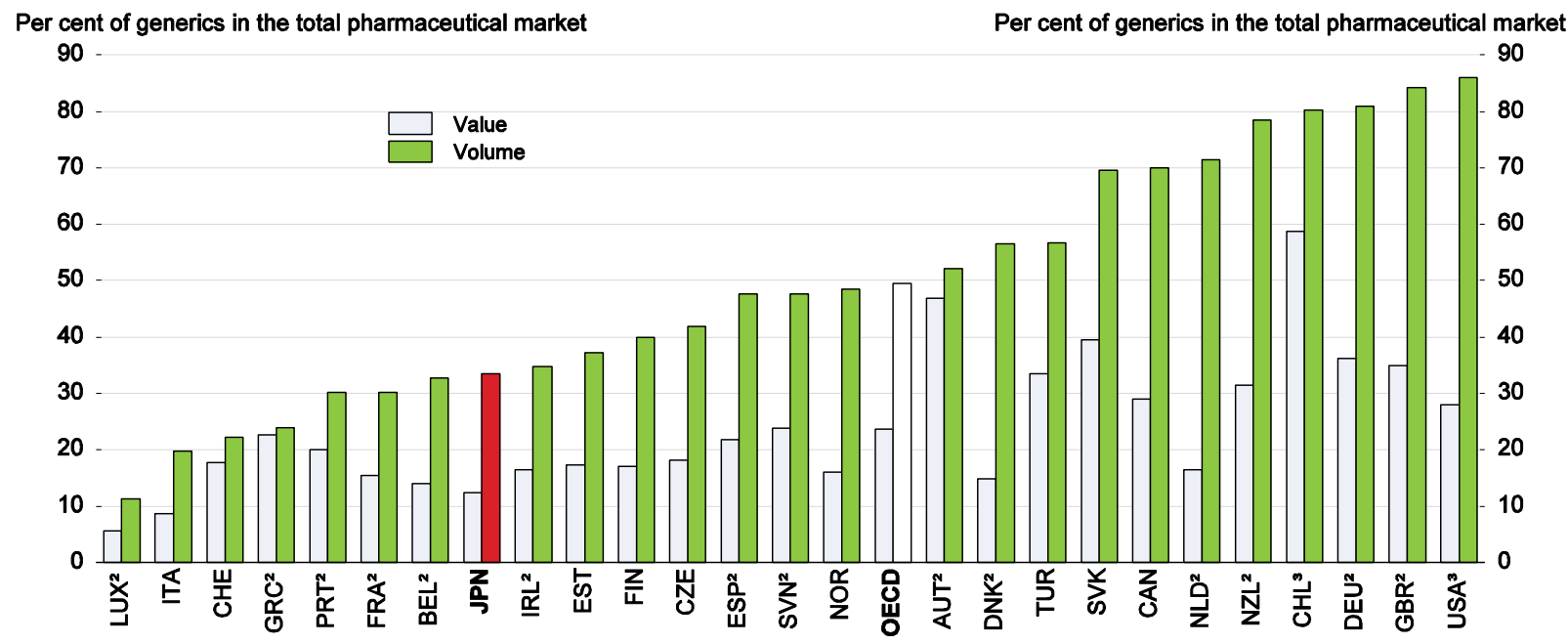

1. Including medical non-durables.

2. Reimbursed pharmaceutical market.

3. Community pharmacy market.

Source: OECD (2017d), OECD Health Statistics (database).

\section{Outpatient care}

Outpatient care accounted for $20 \%$ of the rise in health spending over FY 2000-14 (Figure 10). Japan stands out for its exceptionally frequent medical consultations, which averaged 12.8 times per year per capita, almost double the OECD average (Table 4). The number of visits is particularly high among the elderly: $58 \%$ of the population over age 60 use medical care at least once a month, well above other major countries, even though elderly Japanese claim to have relatively good health (Figure 12).

Table 4. International comparisons show room for healthcare cost savings in Japan

In 2014 or latest year available

\begin{tabular}{|l|c|c|c|c|c|c|c|c|}
\hline & $\begin{array}{c}\text { Number of } \\
\text { doctor } \\
\text { consultations } \\
\text { per capita } \\
\text { per year }\end{array}$ & $\begin{array}{c}\text { Share of } \\
\text { private } \\
\text { expenditure } \\
\text { on outpatient } \\
\text { care (\%) }\end{array}$ & $\begin{array}{c}\text { Average } \\
\text { total } \\
\text { hospital } \\
\text { stay }^{1}\end{array}$ & $\begin{array}{c}\text { Average } \\
\text { hospital } \\
\text { stay for } \\
\text { acute } \\
\text { care }^{1}\end{array}$ & $\begin{array}{c}\text { Total } \\
\text { number of } \\
\text { hospital } \\
\text { beds }^{2}\end{array}$ & $\begin{array}{c}\text { Number } \\
\text { of acute- } \\
\text { care } \\
\text { beds }^{2,3}\end{array}$ & $\begin{array}{c}\text { Number } \\
\text { of long- } \\
\text { term } \\
\text { care } \\
\text { beds }^{2,3}\end{array}$ & $\begin{array}{c}\text { Number of } \\
\text { beds in } \\
\text { long-term } \\
\text { care } \\
\text { facilities }^{2}\end{array}$ \\
\hline Japan & $\mathbf{1 2 . 8}$ & $\mathbf{1 7 . 1}$ & $\mathbf{2 9 . 9}$ & $\mathbf{1 6 . 9}$ & $\mathbf{1 3 . 2}$ & $\mathbf{7 . 9}$ & $\mathbf{2 . 7}$ & $\mathbf{6 . 2}$ \\
\hline $\begin{array}{l}\text { OECD } \\
\text { average }\end{array}$ & 6.8 & 33.3 & 8.3 & 6.4 & 4.7 & 3.6 & 0.6 & 7.3 \\
\hline $\begin{array}{l}\text { Highest } \\
\text { country }\end{array}$ & 14.9 & 54.9 & 29.9 & 16.9 & 13.2 & 7.9 & 4.2 & 12.8 \\
\hline $\begin{array}{l}\text { Lowest } \\
\text { country }\end{array}$ & 2.6 & 13.3 & 4.0 & 3.5 & 1.6 & 1.6 & 0.0 & 0.5 \\
\hline
\end{tabular}

1. In days.

2. Per 1000 population.

3. In hospitals.

Source: OECD (2017d), OECD Health Statistics (database).

The high use of outpatient care is, in part, supply-induced. One study showed that the volume of outpatient care for diabetes and high blood pressure is positively associated with the regional density of doctors, while there was no relation to patients' health conditions (Ii and Sekimoto, 2014). Containing outpatient spending requires shifting from a fee-for-service to a pay-for-performance system, which offers 
financial incentives to providers to meet performance measures, and the standardisation of treatment to reduce the number of doctor consultations. Allowing nurse practitioners to provide primary care could also lower costs, while increasing patient satisfaction and providing high-quality care (Horrocks et al., 2002).

Low out-of-pocket payments are another factor driving the frequency of medical consultations: private expenditure covers only $17.1 \%$ of the cost of consultations compared to the OECD average of $33.3 \%$ (Table 4). Most persons aged 70 or more face co-payments of only $10 \%$ (except those earning as much as the working age-population, who pay the standard 30\% rate). Persons between the ages of 70 and 74, who reached age 70 after April 2014, now pay 20\%, which is a step in the right direction. In addition, co-payments for outpatient care are limited to a ceiling of 12000 yen (USD 106) per month for most persons 70 years or older. It will be increased in two steps to 18000 in 2018, still well below the 57600 yen (USD 510) ceiling for persons below age 70.

The low co-payment rate and the upper limit on co-payments for the elderly increase the quantity of outpatient care, but have little positive effect on patient health (Shigeoka, 2014). Low co-payments for the elderly were originally aimed at protecting those with low income. However, a government survey found that only $9 \%$ of the population age 75 and over found the co-payment to be burdensome, compared to $20 \%$ in the working-age population (MHLW, 2013). The standard co-payment rate for those aged 75 or older should be increased to the $20 \%$ paid by the $70-74$ group. In addition, introducing a small flat-rate fee on outpatient care for all age groups would increase the current low share of out-of-pocket payments. The ceiling on co-payments for outpatient care for those aged 70 or older should be increased to the same level as for inpatient care, while ensuring that low-income elderly do not lose access to necessary healthcare.

Figure 12. The elderly in Japan make frequent use of medical services

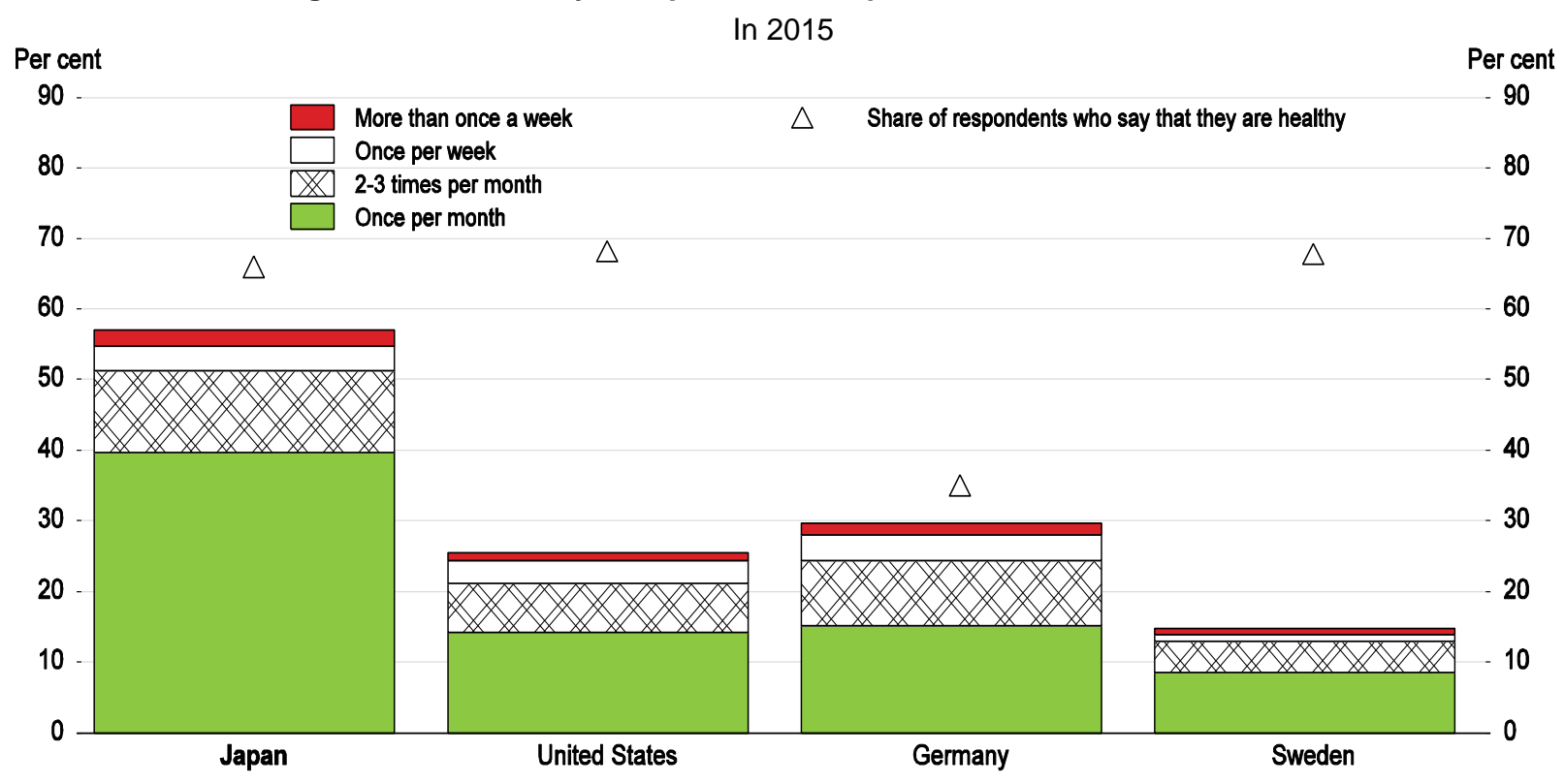

Source: Cabinet Office (2016d).

\section{Inpatient care}

Low co-payments are also problematic for hospital care, which accounted for $36 \%$ of the rise in health spending over FY 2000-14 (Figure 10). The co-payment rate is reduced to 10\% for persons above age 75, compared to $30 \%$ for the working-age population. The co-payment rate and ceilings on co-payments for the elderly with income in the middle and low-income brackets should be more in line with those for working-age persons. 
Japan stands out for its exceptionally long hospital stays, which averaged 29.9 days in 2014, almost four times the OECD average (Table 4). This partly reflects the provision of long-term care in hospitals, which is much more expensive (Jones, 2009). Indeed, long-term care beds in hospitals cost up to 596000 yen (USD 5 245) per month, more than double the cost of beds in long-term care facilities. The higher cost of long-term care in hospitals reflects regulations on the number of medical staff and equipment. In addition, many acute-care beds in hospitals are used entirely for long-term care. Only about half of hospital patients in acute-care beds even receive healthcare, with the remainder just getting help with daily living at most (Tsutsui et al., 2015). This approach is wasteful given the much higher costs of hospital care: the basic hospital fee in 2016 for the first month was 571020 yen, again more than double the fee in long-term care facilities. The large profit margins of long-term care in hospitals resulted in a sharp rise in capacity over 2006-13 (Cabinet Office, 2014b). To reduce the number of such beds, the government decided in 2016 to tighten the definition of acute care. To further remedy this misallocation of resources, the reimbursement of long-term care beds by public health insurance needs to be reduced.

Long hospital stays are linked to the number of hospital beds, which is the highest in the OECD (Table 4), reflecting the number of acute-care beds (highest in the OECD) and the number of long-term care beds (second highest). In addition, the regional variation in the number of hospital beds per capita is by far the highest in the OECD (OECD, 2015c). As is the case for outpatient care, supply induces demand (Yamada, 2002; Yuda, 2013): the number of hospital beds by prefecture is strongly correlated with the hospitalisation rate (Figure 13). Moreover, the higher the number of beds in a prefecture, the longer the average hospital stay and the higher the costs (Panel B). Reducing the number of hospital beds where they are in over-supply is thus essential to cut the hospitalisation rate and the length of hospital stays, which at 16.9 days for acute-care beds, is the longest in the OECD and far above the average of 6.4 days. This requires weakening the incentives to keep unused hospital beds in public and private hospitals. The latter have $71 \%$ of hospital beds.

The Economic and Fiscal Revitalization Action Program aims to reduce regional differences in health and long-term care spending (Box 1). Towards this end, the central government requires prefectures to develop community healthcare visions by March 2017 based on guidelines issued in 2015. The visions should project healthcare demand in 2025 and specify the function of each hospital, while promoting coordination between them. Each prefecture is divided into areas based on factors such as population and the time needed to reach a major hospital. Each area is expected to cut its hospitalisation rate in long-term care hospital beds to the most efficient prefecture in 2013 or by the ratio of the least efficient prefecture to the median prefecture in 2013.

The projection for healthcare demand in 2025 is based on the hospitalisation rate in 2013. With the hospitalisation rate on a downward trend, falling 9\% between 1999 and 2011, basing projections on the 2013 rate may not be sufficiently ambitious. In addition, the guideline is a "reference" for a "flexible" target-setting process (Maeda, 2015), which may allow prefectures to avoid difficult choices. The government should strictly monitor the prefectural medical plans, in particular to promote the shift of hospital beds to long-term care facilities to boost efficiency and enhance the satisfaction of recipients.

Shifting further from a fee-for-service system to a diagnosis-related group approach is another priority. In 2003, Japan introduced a case-mix based payment system, the Diagnosis Procedure Combination (DPC), which sets an overall fee according to the illness, while promoting the standardisation of treatment and length of hospital stay. The DPC needs to be made more effective by increasing the coverage of hospitals and illnesses and basing fees on the most efficient hospitals. Finally, efficiency in healthcare, as well as other social services such as long-term care, should be increased by eliminating rules that limit or prohibit the entry of corporations, thereby protecting social welfare organisations (Jones and Jin, 2017). For example, rules limiting the management of hospitals and clinics to medical doctors and restrictions on equity finance should be abolished (2015 OECD Economic Survey of Japan). 
Figure 13. The higher the number of beds, the longer are hospital stays, leading to greater health spending In 2014
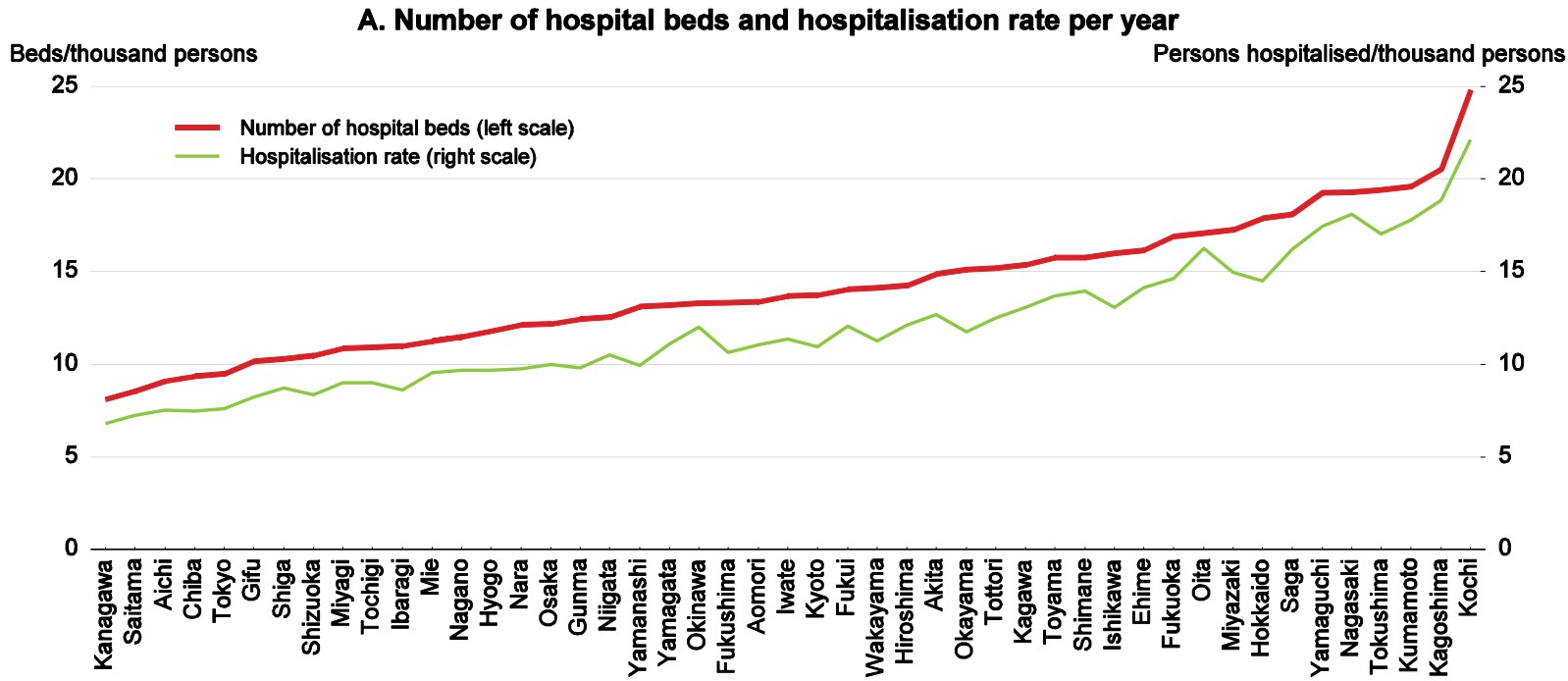

B. Number of hospital beds, average length of stay and per capita health spending

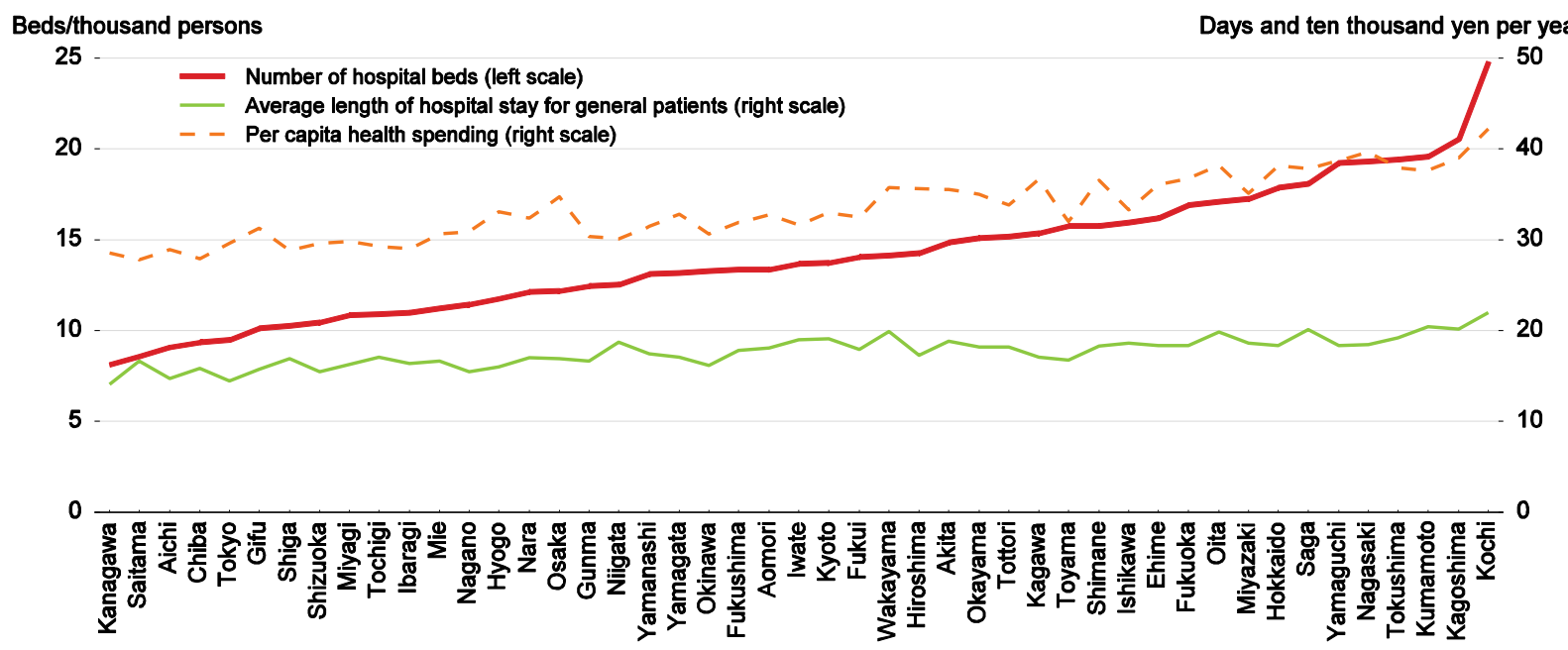

Source: Cabinet Office, Visualization Database.

\section{Long-term care}

Following the introduction of long-term care insurance in 2000, long-term care spending increased by 2.6 times by FY 2014, the most among social security programmes (Figure 14). The number of care recipients rose by 3.3 times over that period, reaching $17.8 \%$ of the elderly population, the fourth highest in the OECD and well above the OECD average of $11.8 \%$. The long-term care insurance premium, which must be paid by everyone aged 40 and over, increased by 2.6 times for persons aged 40-64 over FY 200016 and by 1.9 times for those over 65. The government projects that the pace of increase in long-term care spending will continue to be the fastest among social insurance programmes (Figure 7).

The share of long-term care recipients receiving care at home is high, reflecting generous insurance coverage for such assistance. Indeed, "living support" (i.e., housecleaning, shopping, cooking, etc.) is covered by insurance, with low co-payment rates of $10 \%$. Day service - elderly persons visiting long-term care facilities for meals and bathing - is also popular. In some cases, it is just entertaining elderly persons, 
even including casino-type activities. The variation between prefectures in per capita spending for home care, living support and day service is larger than for care provided in long-term care facilities, even after adjusting for age composition (Hida, 2015). Around two-thirds of those using living support and day service have needs that are classified as "less severe" (level 2 or below). Living support and day services for those with less severe needs should be excluded from long-term care insurance, and should instead be provided by local governments. In addition, the scope for combining care not covered by insurance with that which is covered (so-called "double billing") should be expanded.

Figure 14. Long-term care expenditure has more than doubled in 14 years

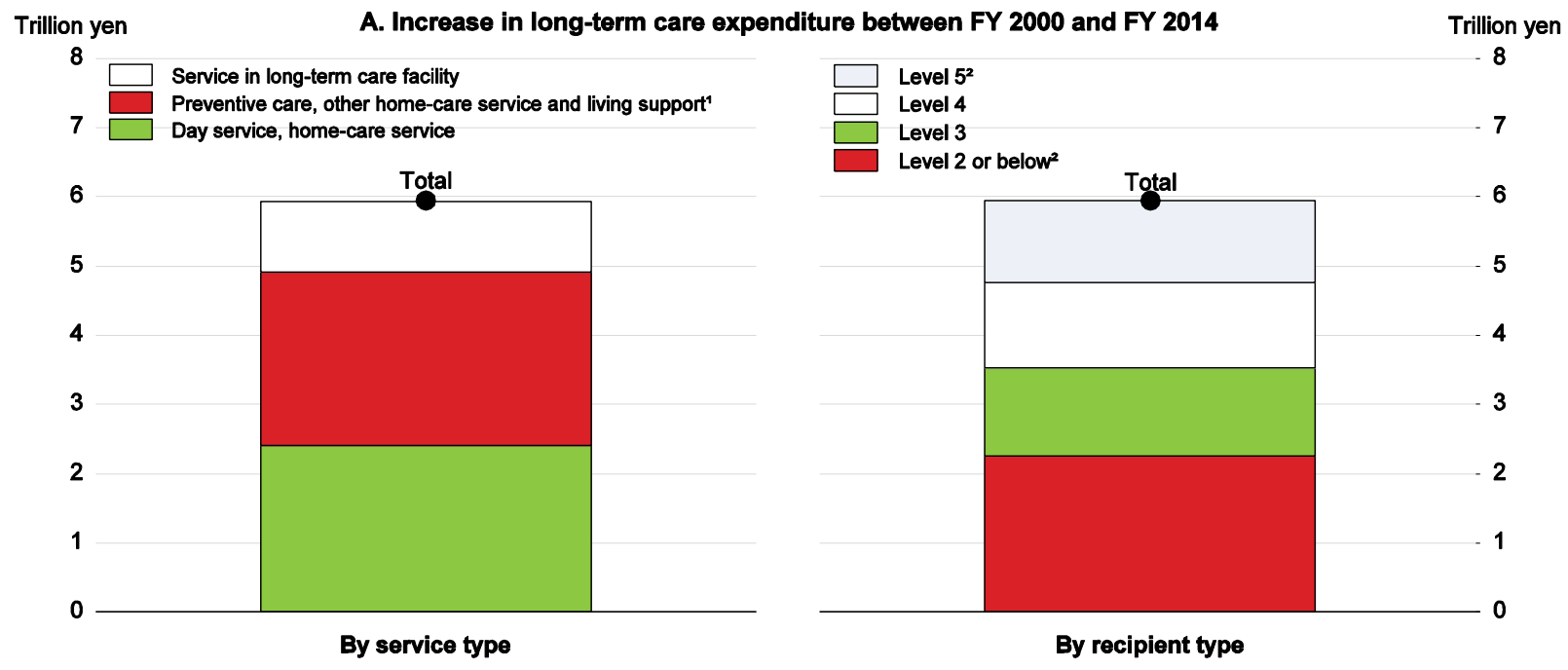

B. Regional differences in expenditures and eligibility rates for long-term care insurance

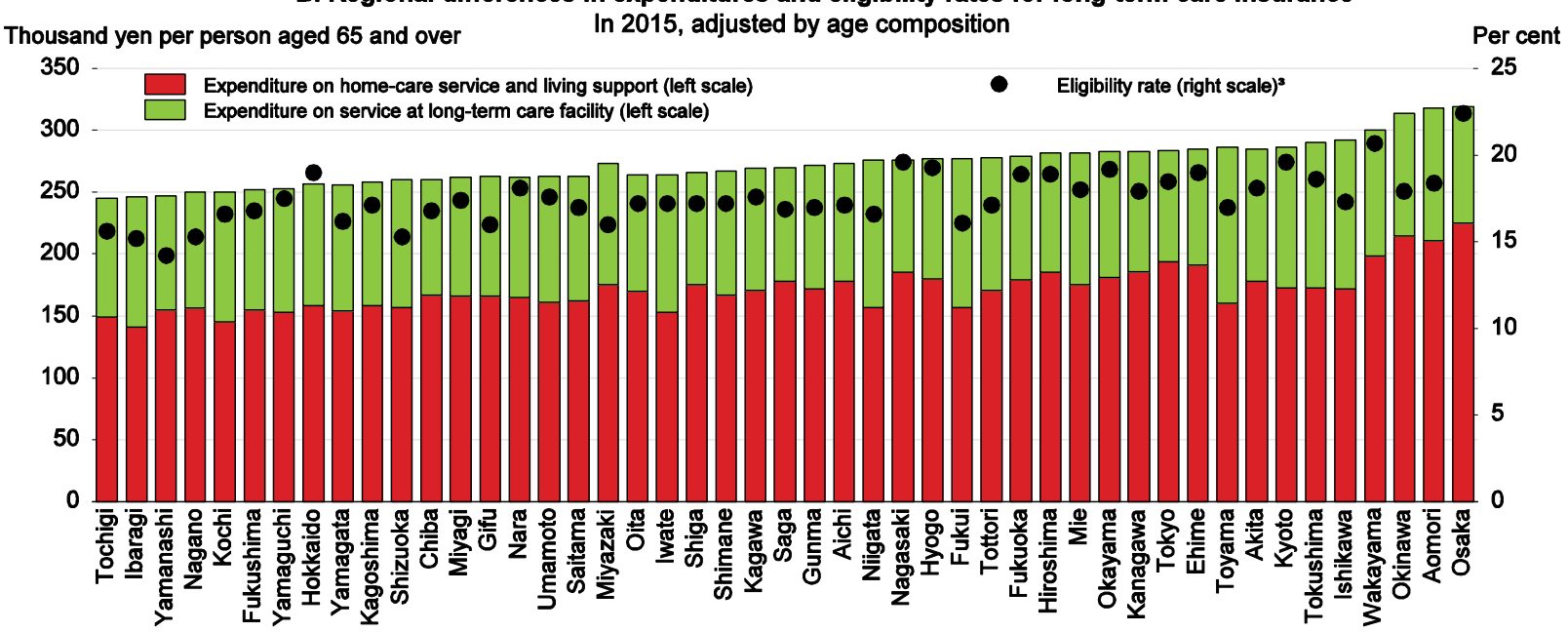

1. Preventive care and other home care include short-stay service, rental of welfare equipment and fees for home repair, etc. Preventive care services started in 2006.

2. Level 5 is the highest level of need for long-term care and level 1 the lowest. Under care level 1, there are two levels of need for assistance.

3. In order to use long-term care insurance to receive long-term care, the person must first obtain a long-term care certification. The eligibility rate is the share of persons certified as needing long-term care or assistance as a share of the population over age 65.

Source: Ministry of Health, Labor and Welfare, Survey of Actual Condition of Long-term Care Benefits in FY 2000 and FY 2014.

A number of studies have found insurance-induced demand both for living support and day service (Yuda, 2005; Tajika and Yui, 2004) and for care at facilities (Hida, 2015). One reason is moral hazard between individuals who want to receive care and business entities that want to provide it (Tajika and 
Kikuchi, 2006). In addition, municipalities face a conflict of interest between encouraging such care, which boosts local firms and employment, and appropriately administering the insurance. Moreover, municipal governments have insufficient financial resources to act as insurers, a role that should be shifted to the prefectural level. Some supply controls should also be considered, including reintroducing volume control for facility-based services, which had been abolished in 2012 .

Increasing co-payments is another priority to limit the projected rise in long-term costs (Figure 7). Private expenditure covered $8.6 \%$ of long-term care spending in 2013, much lower than the $15.7 \%$ for total health spending. In 2015, the government increased the co-payment rate to $20 \%$ and it plans to raise it further to $30 \%$ in 2018 , in addition to raising the monthly payment ceiling by $19 \%$ to 44000 yen (USD 387) per household. However, these reforms apply only to elderly earning as much as the working-age population, who are likely to be relatively few. Further increasing the co-payment rate to the level applied to overall health spending is essential.

\section{Pension reform}

The failure to set pension benefits based on the indexation plans in place has led, cumulatively, to excess payments of 41 trillion yen (7.6\% of 2016 GDP) since FY 2000 (Figure 15). This reflects: $i$ ) the suspension of price indexation over 2000-14 in the context of deflation; ii) the effect of not moving to wage indexation in FY 2000; and iii) the effect of not fully applying macroeconomic indexation:

- Price indexation of benefits was suspended in the early 2000s. Consequently, pension benefits fell only 2\% over FY 1999-2012 (first line), rather than matching the 5\% drop in the CPI (second line). The failure to index benefits resulted in 9 trillion yen of excess pension payments (the area between the first and second lines) over FY 2000-14.

- In 2004, the government decided to adjust pension benefits in line with wage growth when it is less than CPI inflation (as long as both were positive). When wage growth is negative, the pension revision is based on CPI inflation or zero (whichever is lower). This approach left the pension benefit rate 1\% higher in FY 2016 (the third line). Under the 2016 reform that will be implemented in FY 2021, benefits will be based on wage growth when it is negative and less than CPI inflation. If this reform had been introduced in 2005, pension spending would have been 8 trillion yen lower (the area between the second and third lines). This overpayment will continue until FY 2021.

- In 2004, the government introduced "macroeconomic indexation", which adjusts pension benefits based on changes in the number of contributors and life expectancy. However, it was not applied when inflation was negative. Had it been fully implemented, the benefit level in FY 2016 would have been 13.5 percentage points lower (fifth line) than the level actually paid (first line). Under the 2016 reform, a carryover system will be introduced in FY 2018 in which benefit revisions that are cancelled in years of negative inflation are added in later years (fourth line). If the carryover provision had been introduced in 2005, pension payments over FY 2005-16 would have been 8 trillion yen less (the area between the third and fourth lines). 
Figure 15. Problems in Japan's pension system
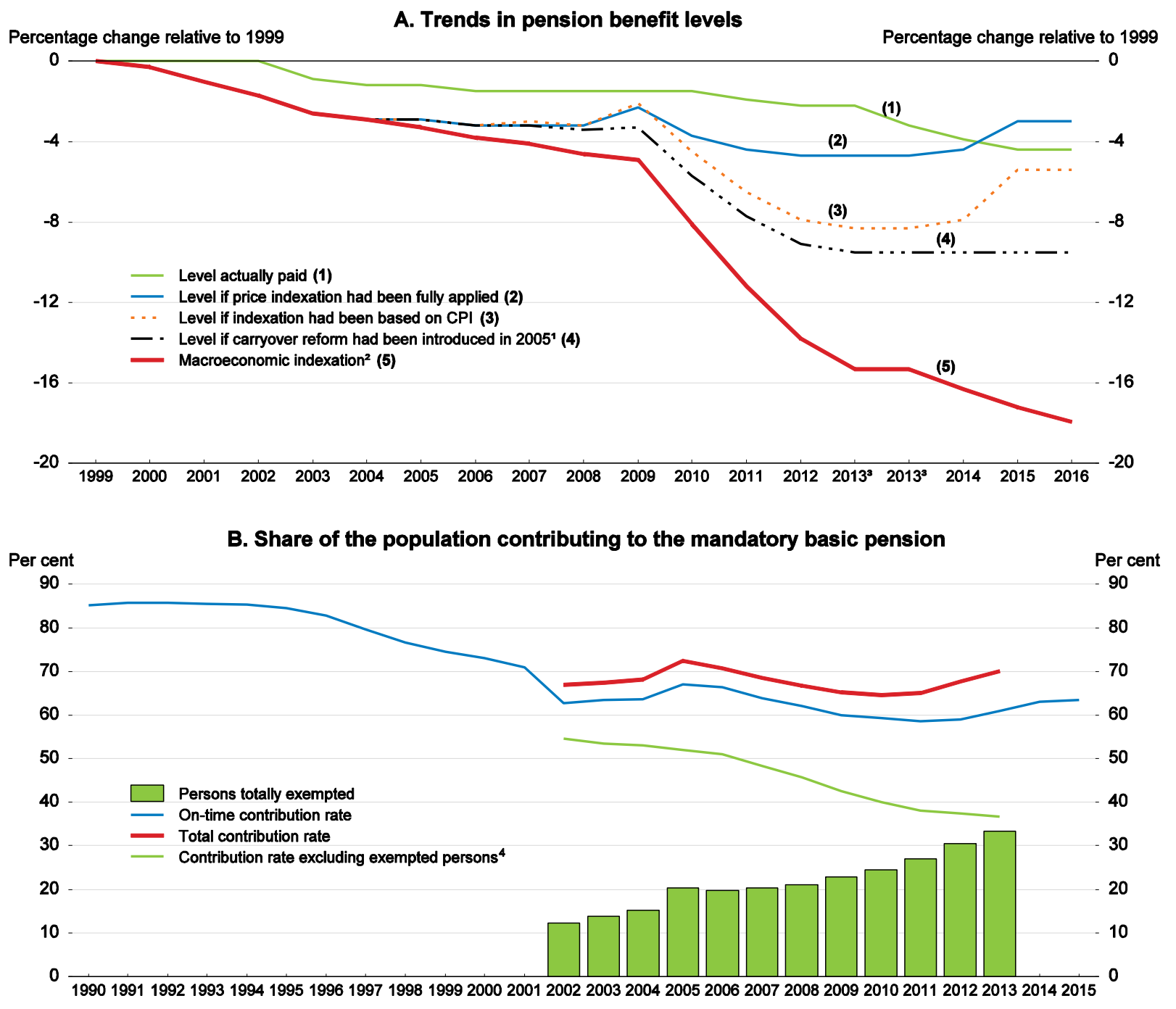

1. Level of pension benefits paid if reform decided in 2016 were applied since 2005.

2. Level of pension benefits paid compared to the level if macroeconomic indexation had been fully applied, even during periods of deflation.

3. There were two revisions in 2013 (April and October).

4. This measure excludes only those who are totally exempted from contributions (but not those partially excluded).

Source: Nakajima (2016); Ministry of Health, Labor and Welfare, Participation and Payment of the National Pension.

Excess pension payments have contributed to a depletion of the pension reserve fund averaging around 5 trillion yen (1\% of GDP) since FY 2009, despite the rise in the pension contribution rate from $13.6 \%$ in FY 2004 to $18.3 \%$ in FY 2017. To limit pension spending, macroeconomic and price indexation should be allowed to operate fully, even under deflation or low inflation of around $1 \%$ or less. Otherwise, pension benefits will remain higher than intended.

The share of the population contributing to the mandatory basic pension has remained around $68 \%$ since FY 2002 (Figure 15, Panel B). If persons whose contributions are exempted are excluded, the actual contribution rate was $36.7 \%$ in FY 2013. With fewer people eligible to receive the basic pension benefit in the future, outlays under the main social welfare programme, the Basic Livelihood Protection Program (BLPP), are projected to rise from 0.75\% of GDP in FY 2015 to 1.7\% in FY 2050 (Yoneda et al., 2015). 
The share of the population contributing to the mandatory basic pension is lower among youth, suggesting that they have less confidence in its future, as well as lower incomes (see below). The contribution rate is also low among non-regular workers: the share who have paid contributions for 40 years is only $30 \%$, compared to $60 \%$ for the self-employed (Oshio, 2013).

In addition, many small firms do not participate in the Employees' Pension Insurance (EPI), although it is legally mandatory. In 2014, an estimated 0.8 million business entities (out of a total of 2.5 million) deducted personal income tax payments from their workers' salaries at source, but did not pay pension insurance premiums for them. It is necessary, therefore, to strengthen the enforcement of the EPI.

To contain the growth of pension spending, increasing the pension eligibility age is a priority (2015 OECD Economic Survey of Japan). Even after the age for the EPI is raised to 65 by 2025 for men and 2030 for women, it will remain relatively low compared to Japan's life expectancy, which is now the world's longest at 81 years for men and 87 for women. Accelerating the increase in the eligibility age to 65 and raising it further would improve intergenerational equality and lift output growth. Government simulations suggest that raising the eligibility age from 65 to 68 by FY 2033 would keep the pension replacement rate at close to its current level (Table 5). A further increase to 70 years would allow a significant rise in the replacement rate and a reduction in government outlays on pensions. In 2014, the share of the Government Pension Investment Fund held in equities was increased from 25\% to 50\%, equally split between domestic and foreign shares, while cutting the share of government bonds. This should lift the Fund's return, given very low interest rates, thereby easing the burden of financing pensions. At the same time, it is important to monitor the associated increase in risk. A 50\% share for equities is around the median in OECD countries (OECD, 2016a).

\section{Minimum-income benefit reform}

Japan's tax and social security benefit system mainly redistributes income from the working-age population to the elderly through social insurance. In addition, more than half of the recipients of the BLPP, the main social welfare programme, are over age 60 (Figure 16). The BLPP assists those with an income below the absolute poverty line who meet the eligibility criteria, which take into account their assets and the ability of family members to provide help. The number of recipients was 2.1 million $(1.6 \%$ of the population) in 2014 , which is low compared to the $16 \%$ of the population in relative poverty, although social insurance programmes also provide assistance. For those who receive it, the BLPP benefit is generous compared to basic social welfare benefits in other OECD countries. In 2014, the benefit for lone parents was the highest in the OECD relative to median income, while that for a single person was the third highest. The BLPP benefit, which is set at the "minimum living standard", is based on the consumption level of the lowest-income families. The high level of benefits and low coverage suggest scope for broadening coverage and reducing benefits.

Table 5. Raising the pensionable age leads to a large increase in the replacement rate Per cent

\begin{tabular}{c|cc|ccc}
\hline \multirow{2}{*}{ Cases $^{\prime}$} & \multicolumn{2}{|c|}{ Real GDP growth rate } & \multicolumn{3}{c}{ Replacement rate $^{2}(\%)$ in 2050 for pension eligibility age of: } \\
\cline { 2 - 6 } Case C & FY 2014-23 & FY 2024 onward & 65 years & 68 years & 70 years \\
\cline { 2 - 6 } & 1.1 & 0.9 & 51.0 & 63.9 & 72.5 \\
Case E & 1.1 & 0.4 & 50.5 & 63.3 & 71.8 \\
Case G $^{3}$ & 0.2 & -0.2 & 42.0 & 52.8 & 60.0 \\
Case H $^{4}$ & 0.2 & -0.4 & 41.9 & 52.7 & 59.8 \\
\hline
\end{tabular}

1. The table shows four of the eight simulations done by the Ministry of Health, Labor and Welfare (2014). Total pension benefit payments are fixed, resulting in variations in the replacement rate.

2. Pension benefit, including the impact of macroeconomic indexation, as a percentage of final earnings. The replacement rate was $62.7 \%$ in FY 2014.

3. For the retirement age of 65 , the replacement rate is for 2058 .

4. For the retirement age of 65, the replacement rate is for 2054.

Source: Ministry of Health, Labor and Welfare (2014); OECD calculations. 
Apart from its narrow coverage, the BLPP has a number of problems. First, it weakens work incentives due to high effective tax rates on persons leaving the BLPP to accept full-time employment. For those who can earn the average wage, the participation tax rate (the proportion of earnings that are lost to either lower benefits or higher taxes and social security contributions) for a single parent was $83 \%$ in 2014, the highest in the OECD. Consequently, persons who qualify for the BLPP tend to receive benefits for a long time. Moreover, the BLPP's medical assistance, which provides free healthcare without any copayment, encourages excessive use of healthcare. Working-age persons covered by medical assistance are hospitalised five times more than those covered by public health insurance, who make co-payments of $30 \%$. Moreover, those with medical assistance receive outpatient care at hospitals more than twice as frequently. The authorities should determine to what extent the higher healthcare demand is due to the poorer health status of BLPP recipients rather than the lack of a co-payment. Introducing a small co-payment could reduce unnecessary healthcare spending.

Figure 16. The coverage of the Basic Livelihood Protection Program is rising

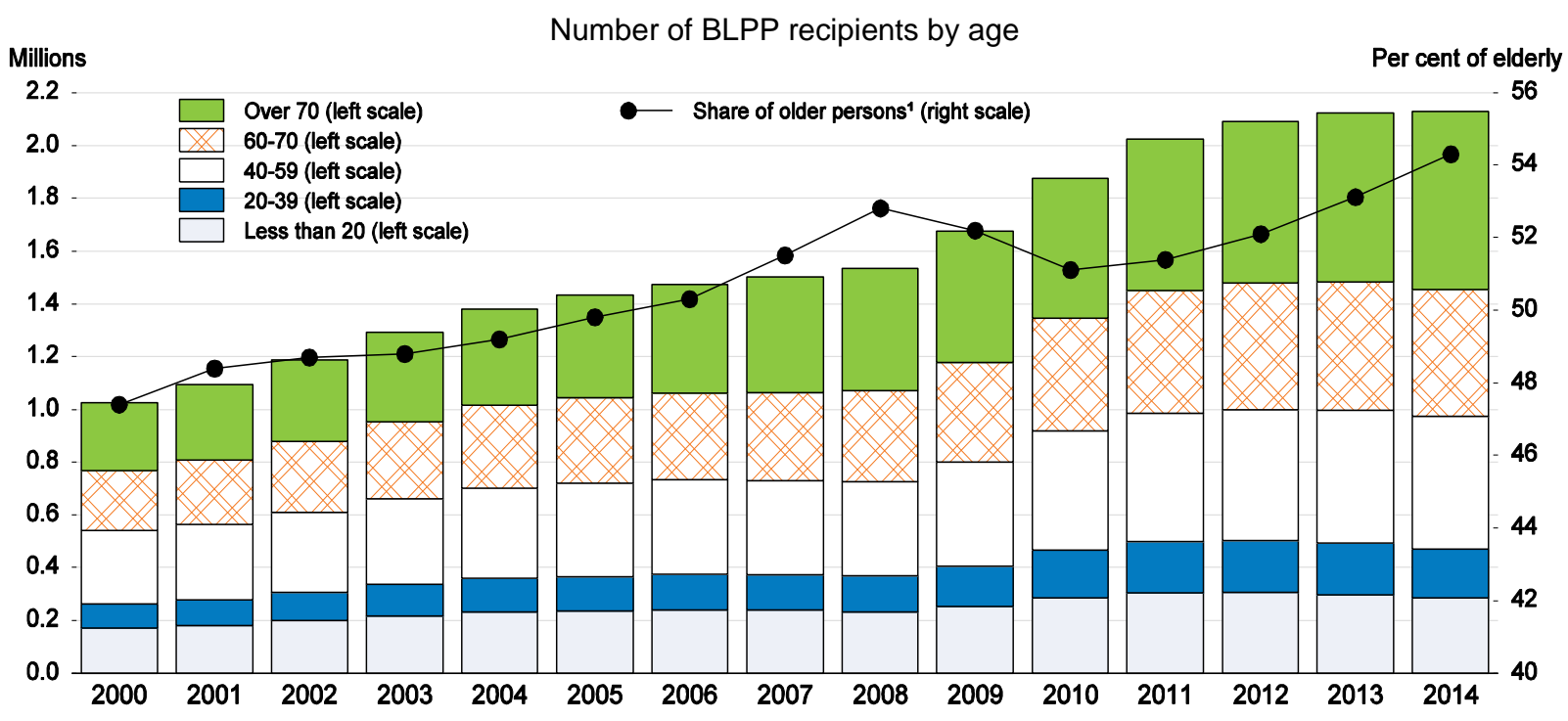

1. Share of recipients over age 60.

Source: Ministry of Health, Labor and Welfare; Ministry of Internal Affairs and Communications.

Reducing the generosity of BLPP benefits would help eliminate the poverty trap. In 2013, some measures to encourage work were taken by revising the work income deduction: $i$ ) the fully deductible limit was raised from 8000 yen per month to 15000 yen (USD 132); and ii) the deduction rate was changed from a range of $0 \%$ to $17.2 \%$ to a flat rate of $10 \%$. A one-time in-work benefit introduced in July 2014 is another step in the right direction: when BLPP recipients leave the Program, they receive a lumpsum benefit based on the amount they earned while receiving public assistance. To further strengthen work incentives, the lump-sum benefit should be raised from its current maximum of $30 \%$ of earned income up to a ceiling of 100000 yen (USD 880) for a single household. In addition, Japan could consider reducing the generosity of the BLPP over time in some cases.

\section{Expanding opportunities for training}

For working-age people with weak skills, it is important to provide training and job support. In 2015, the government introduced a programme to offer comprehensive consultations, including for employment, and training for people in financial distress, but not eligible for the BLPP. In the first year, about 226000 persons received consultations and over $10 \%$ of them found employment. Such an approach should be applied actively to youth not in employment, education or training (NEETs), who numbered 1.8 million 
between the ages of 15 and 29 in 2014 (OECD, 2017a). Expanding active labour market policies would enhance independence and thereby reduce reliance on the BLPP.

The top priority is to introduce an earned income tax credit (EITC) to encourage BLPP recipients to accept employment. Indeed, some countries have negative effective tax rates for those who return to work, thanks to an EITC. An EITC would also reduce the large number of working poor. Japan's share of households in relative poverty despite having two or more workers is the second highest in the OECD. In addition, raising participation in public pensions is important to limit reliance on the BLPP in the future.

\section{Controlling spending by local governments}

\section{Overview of local government fiscal trends and directions}

Local governments, which play an important role in Japan (Box 2), are required to pursue fiscal consolidation in tandem with the central government, as stated in the 2016 Basic Policies. The level of local government spending has been quite constant since 1994, but its composition has changed markedly. On a national accounts basis, public investment has fallen by more than half, while social assistance benefits and other current transfers increased by $82 \%$ and $96 \%$, respectively (Figure 18). On a budget settlement basis, social spending rose by $116 \%$ and now accounts for a quarter of local government outlays (Panel B).

\section{Box 2. Overview of local governments in Japan}

Subnational governments (SNG) in Japan consist of 47 prefectures and 1719 municipalities (810 cities and 909 villages and towns), down from more than 10000 in 1945. Still, more than a quarter of municipalities have less than 10000 inhabitants, limiting efficiency in the provision of public services. SNGs play an important role, supplying many public services important for the daily life of citizens, such as education, long-term care, and police and fire protection. They account for $39 \%$ of national tax revenue and $72 \%$ of national expenditure. In terms of GDP, this puts Japan close to the OECD average (Figure 17).

SNG debt, at $38 \%$ of GDP, is much higher than the OECD average, but accounts for less than one-fifth of general government debt in Japan. Local debt was contained by relatively strict discipline, such as requiring central government approval of bond issuance by SNGs until 2006. Since then, issuance of bonds by SNGs only requires consultation with the central government, as long as debt and deficits are below certain thresholds. Once the thresholds are breached, central government permission is once again necessary.

The gap between SNGs' own resources and their spending requires substantial inter-governmental transfers, which amounted to $7.0 \%$ of GDP in FY 2014. The most important central government transfer to SNGs is the Local Allocation Tax (LAT), a general-purpose block grant that accounted for $17 \%$ of SNG revenue in FY 2014. Earmarked grants, which are conditional or limited to a specific purpose, accounted for another $15 \%$ of SNG revenue. Earmarked grants are distributed by line ministries for designated local projects in education, health, infrastructure and other areas. Decision-making authority rests largely with the central government, which imposes rules and regulations, in part to ensure a high quality of services throughout the country. At the same time, such rules limit the ability of SNGs to innovate and to tailor services to local citizens' preferences. The earmarked transfers finance a portion of project costs, generally at least half, leaving the balance to be covered by SNG revenues and bonds.

The "Trinity Reform" in the early 2000s launched an ambitious reform of SNG financing. It transferred 3 trillion yen $(0.6 \%$ of GDP) of national tax revenue to SNGs and reduced both earmarked grants and the LAT (2005 OECD Economic Survey of Japan). The reform aimed to expand freedom of choice at local levels and reduce incentives that had led to excessive spending on public works (OECD, 2016b). The declining share of public works spending at the SNG level indicates that the latter objective has been achieved (Figure 18). On the other hand, earmarked transfers are used to ensure at least a certain level of growth-enhancing investment and prevent an excessive emphasis on public consumption. 
The LAT revenue is calculated as a function of five national taxes, but the amount of SNG expenditure is decided separately by the local government fiscal plan. The LAT, local tax and other revenue, are consistently below local government expenditure. The gap between expenditure in the fiscal plan and revenue is filled by additional LAT provided by the central government and local government debt. The accumulated central government deficits from filling the gap between the LAT and spending, as determined in the local government fiscal plan, amounts to 80 trillion yen (15\% of 2016 GDP) since 1990 (Ministry of Finance, 2016).

Figure 17. Subnational government revenue, expenditure and debt in Japan relative to the OECD

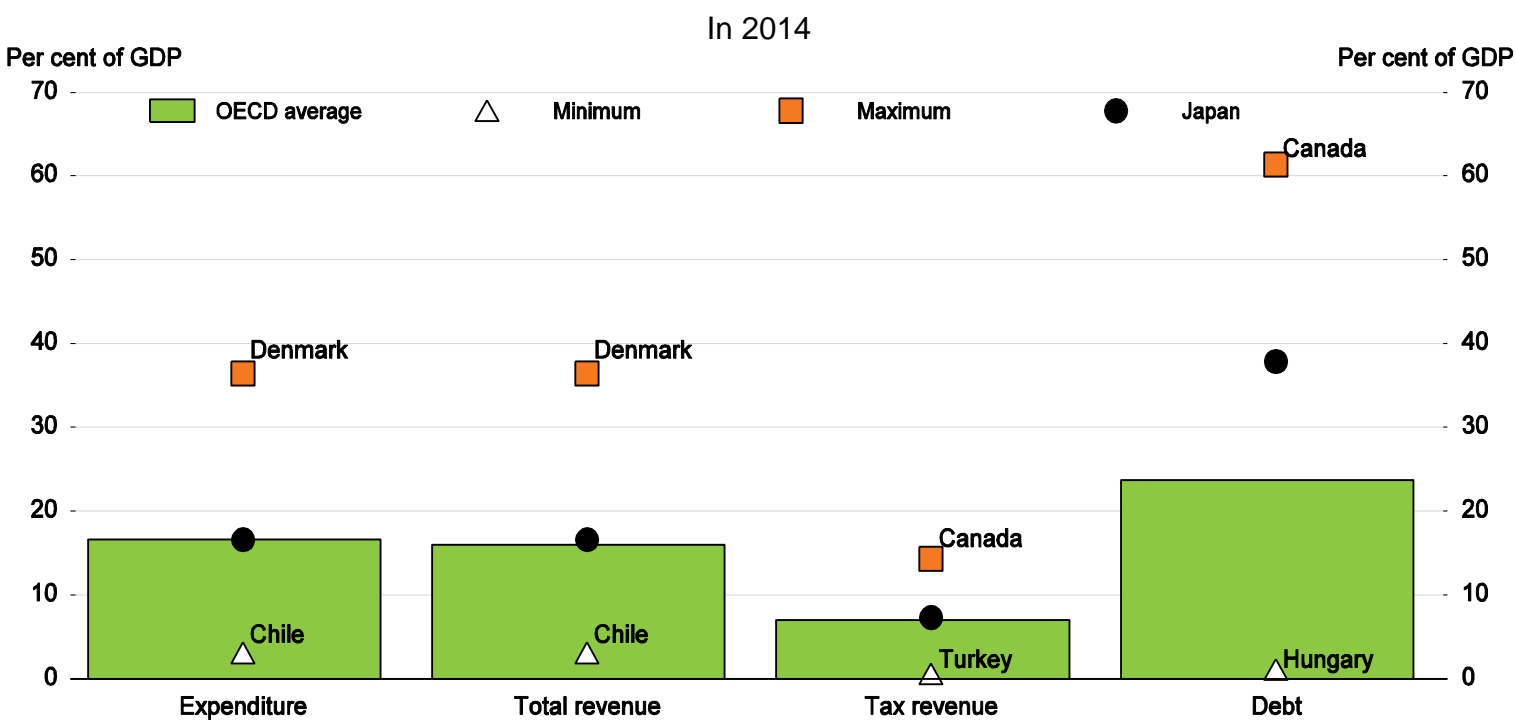

Source: OECD (2016c).

Per capita government expenditure in the highest-spending prefecture (excluding those affected by the Great East Japan Earthquake) was 2.4 times higher than in the lowest-spending prefecture in FY 2014 (Figure 19). The large gap in spending between prefectures suggests scope for reducing spending. Prefectures with high per capita spending also have lower tax receipts per capita and thus rely more on supplementary transfers from the central government and borrowing (Box 2).

Per capita spending increases as the share of elderly in a municipality rises (Figure 20). In addition, per capita spending rises as population density falls (Panel B), reflecting fewer economies of scale. Looking ahead, population decline is projected to accelerate, except in a few major urban centres. Indeed, cities with less than 10000 people will lose almost half of their population by 2050 , according to a government projection (MLIT, 2014). The challenges of depopulation and ageing are already evident in a number of municipalities, such as Yubari (Box 3). Falling population density and an increasing share of elderly will boost per capita spending by municipalities while reducing revenues, leading to increased reliance on central government transfers. LAT outlays are projected to rise by 1.5 times by FY 2030 (Cabinet Office, 2016e). 
Figure 18. Local government expenditure is steady but its composition is changing
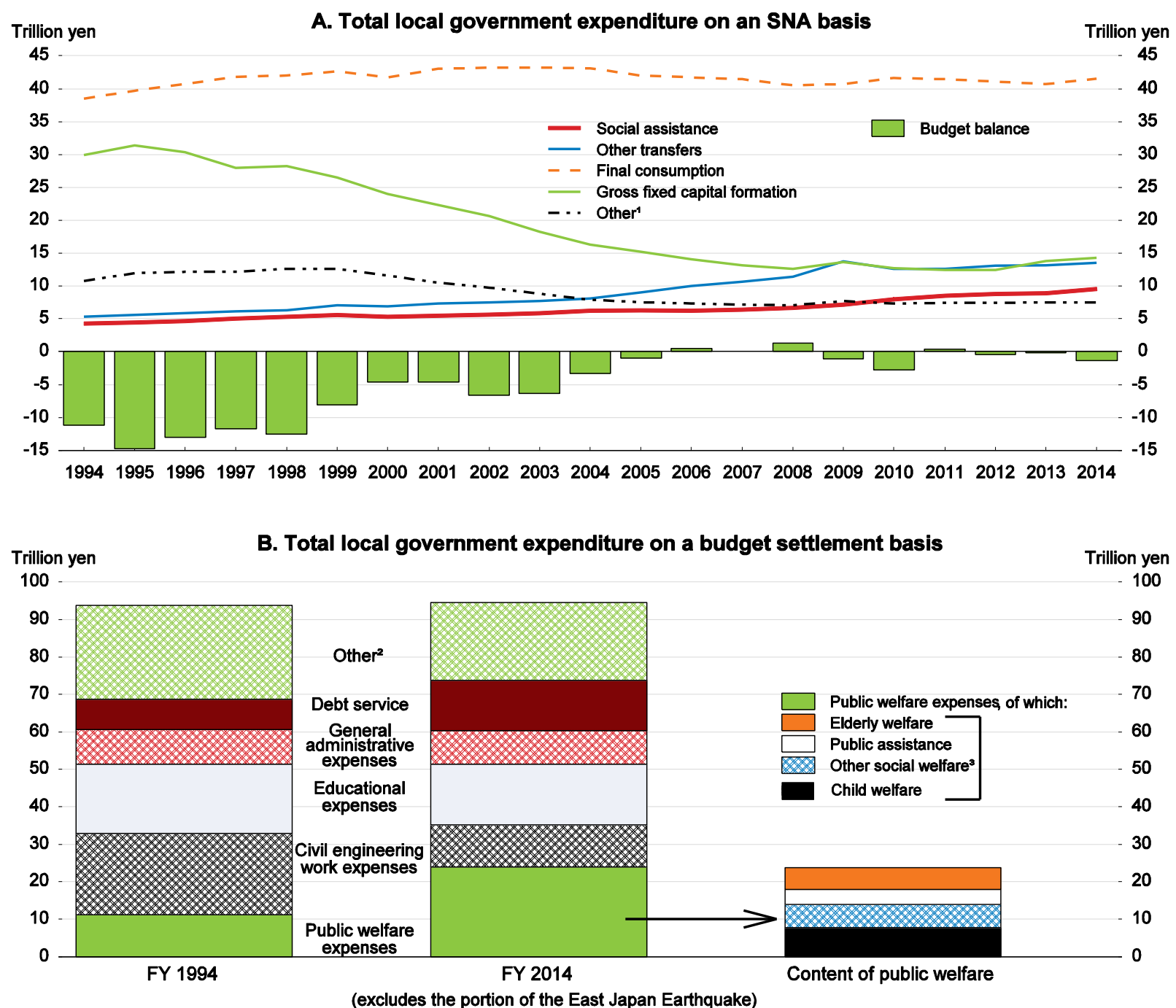

1. Other includes subsidies, property income payment and capital transfer payment.

2. Other includes expenses for sanitation, commerce and industry and agriculture, forestry and fishery, etc.

3. Other social welfare includes assistance for disabled persons, and other comprehensive social welfare measures, etc. Source: Cabinet Office, National Accounts: Ministry of Internal Affairs and Communications.

\section{Achieving fiscal consolidation at the local government level}

The 2015 Basic Policy on Economic and Fiscal Management and Reform stated that "local government expenditures will be controlled in line with the efforts of the central government". Local government revenues are to be maintained at the same level as in the FY 2015 local government fiscal plan until FY 2018. Given Japan's fiscal situation, more ambitious targets for local governments should be considered. The local government fiscal plan should be set in relation to population developments and extra central government support beyond the LAT and earmarked transfers should be limited. Local government should also increase their tax revenue and user fees. Japanese SNGs obtained only 5.8\% of their revenue in 2014 from taxes and fees compared to the OECD average of 14.9\% (OECD, 2016c). 
Figure 19. Differences in per capita spending is largely financed by central government transfers FY 2014

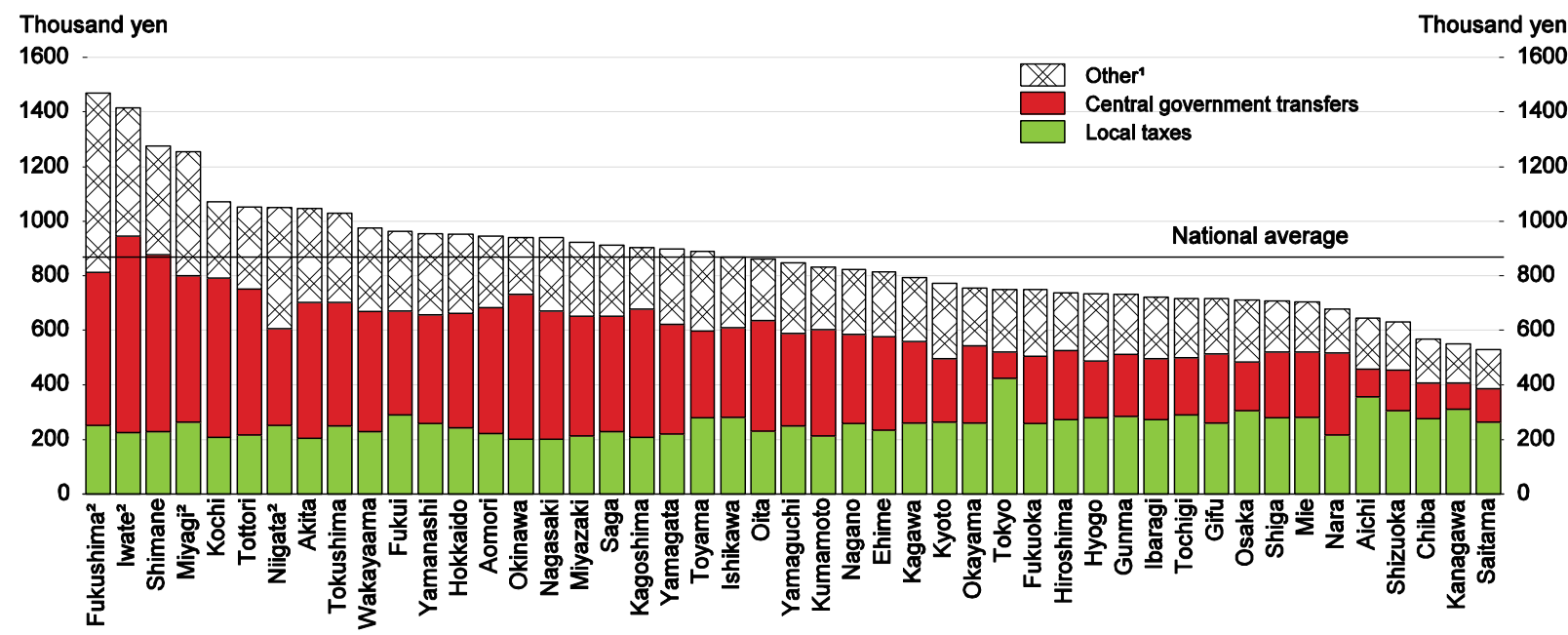

1. Other includes local bonds, loan redemption income, transferred money, balances brought forward, user fees, commissions, etc.

2. Prefectures affected by the Great East Japan Earthquake (Fukushima, Iwate and Miyagi) received money from a fund financed by national treasury disbursements. The "other" category of Niigata prefecture is high because of the loan principal and interest income from the Niigata Prefecture Chuetsu Earthquake Reconstruction Fund.

Source: Cabinet Office (2016a).

Figure 20. Spending by municipalities is driven up by ageing and falling population density In 2010 for 1741 municipalities $^{1}$
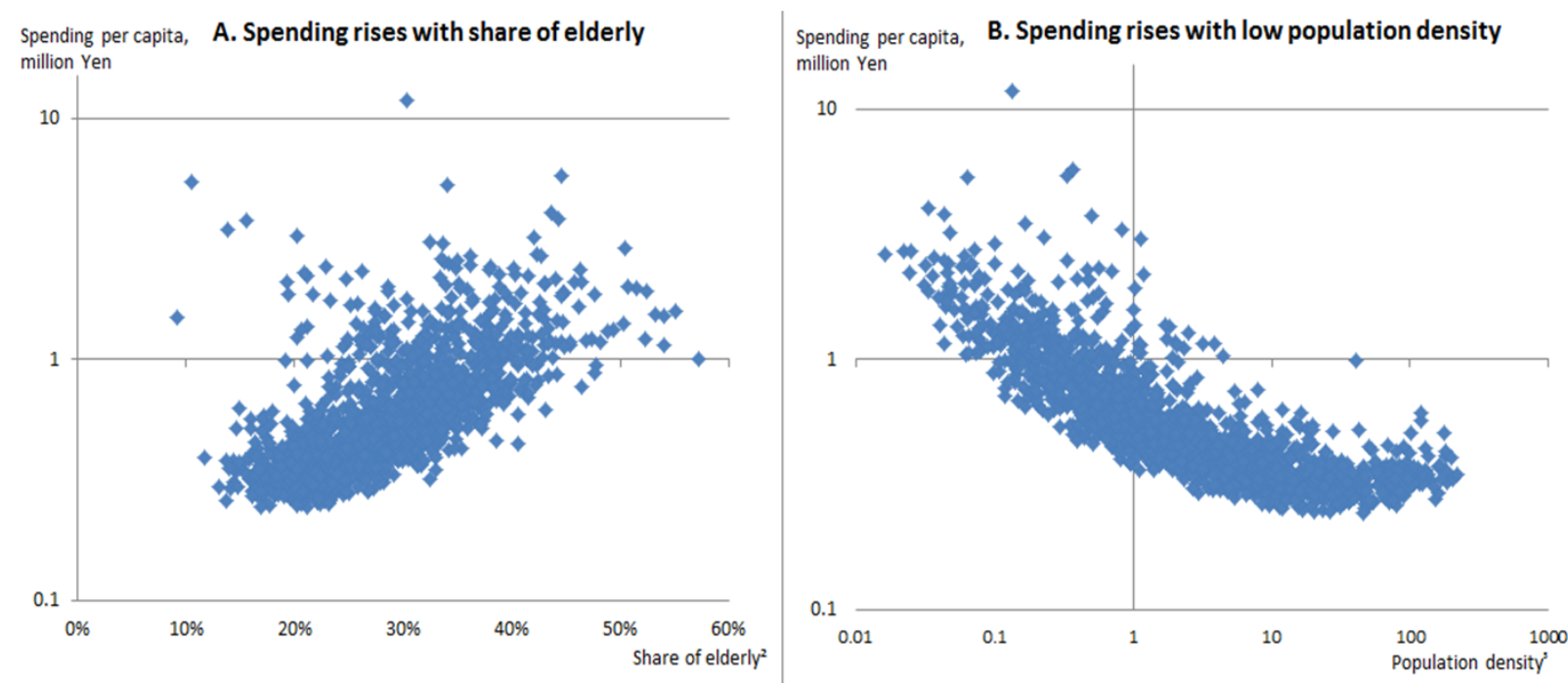

1. Logarithmic scales, except for the horizontal axis in Panel A.

2. Share of population aged over 65 in the total population.

3. In persons per square hectare.

Source: Cabinet Office, Visualization Database. 


\section{Box 3. Policies to cope with population decline and ageing}

Yubari, once a major coal-mining town in Hokkaido, declared bankruptcy in 2006 when its debt was large enough to have a nationwide impact. Under the leadership of its young mayor, Naomichi Suzuki, it is taking unprecedented measures to meet a severe fiscal crisis in the face of a declining population. Yubari provides a case study for hundreds of other local governments facing similar challenges.

Yubari's population peaked in 1960 at 117000 (Figure 21). However, following the shift in the national energy policy from coal to oil in 1959, its coal industry declined rapidly and its last mine closed in 1990. Yubari then pursued a policy "from mines to tourism", aided by subsidies from the central and prefectural governments to build tourist attractions, such as a coal-mining museum. However, faced with severe competition, the tourism effort failed (Seaton, 2010) and the population dropped below 10000 in 2014. Yubari is famous for its melons: in a 2016 auction, a pair sold for 3 million yen (USD 26 400). But melons have not been able to replace coal as an economic base. With young people leaving the town, persons over age 65 now account for half of the population.

Figure 21. The decline in Yubari's population is projected to continue ${ }^{1}$

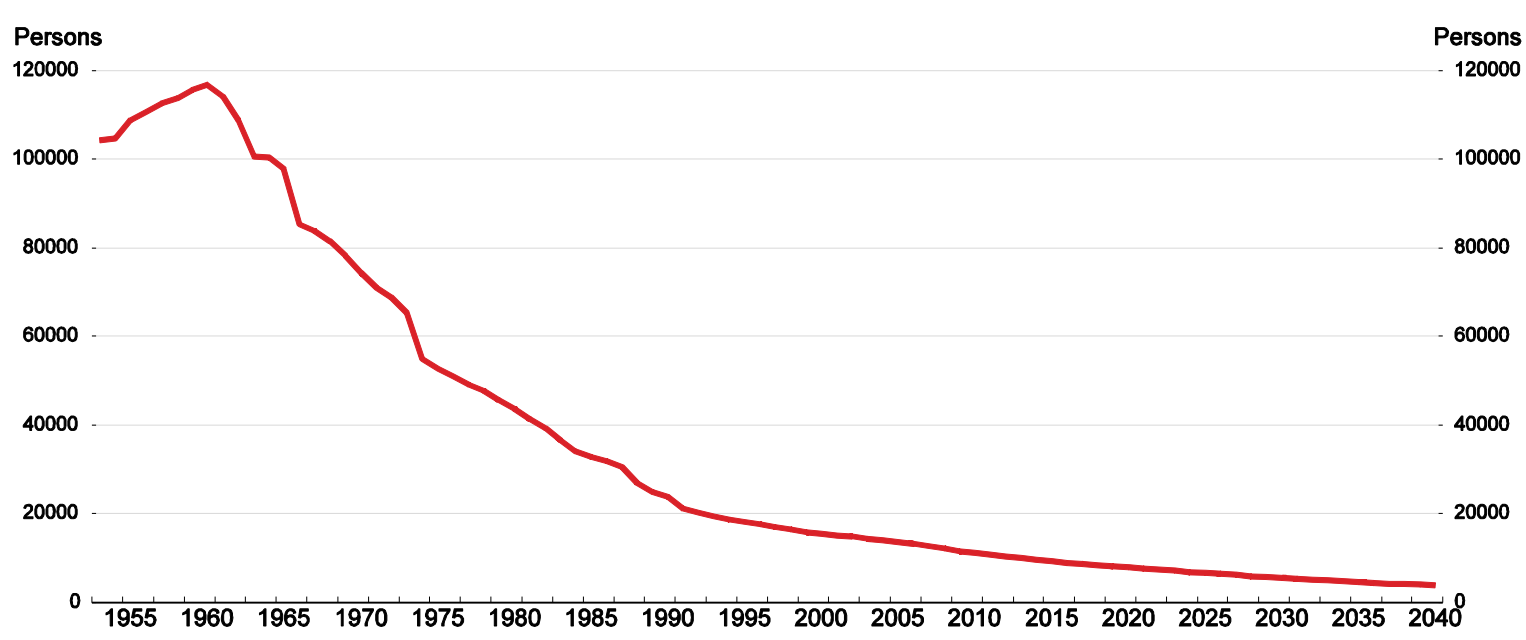

1. The projection from 2017 onwards is from the National Institute of Population and Social Security Research.

Source: Yubari City (2016); National Institute of Population and Social Security Research (2013).

Yubari's fiscal problems were provoked by several factors:

- Public investment soared in the unsuccessful effort to attract tourism.

- Yubari spent 58.3 billion yen (USD 513 million) over 1974-94 to purchase assets, such as apartments, hospitals, and water and sewage facilities, owned by departing coal-mining companies (Tsujido, 2010).

- Local tax revenue and the LAT transfer from the central government shrank sharply with the closure of coal mines and depopulation.

- The size of the problem was hidden by accounting fraud.

By 2006, Yubari's debt had reached 35.3 billion yen, which was eight times its annual general revenue, including the LAT and other central government transfers (Kato, 2016). In 2007, the city drafted a Financial Restoration Plan to pay back the debt over 2007-25 under the supervision of the central government and the Hokkaido prefectural government. Revenue was increased by raising the municipal income tax and fixed-income tax rates to the highest levels allowed and charging for garbage collection. On the spending side:

- The number of city officials was slashed from 269 in 2006 to 103 in 2010, reducing the number per resident to the lowest among towns in the same size category as Yubari.

- Salaries of city officials were cut by $30 \%$ on average to the lowest level in Japan, while the mayor's salary was reduced by $70 \%$. 
- $\quad$ Current expenditures were sharply reduced: spending on goods fell by $40 \%$ and subsidies by $80 \%$.

- Schools were consolidated: by FY 2011, six elementary schools and three junior high schools had been combined into one school at each level.

- Facilities such as parks, swimming pools, and public long-term care facilities were closed.

- The public hospital was scaled down to a clinic, which is now run by a private entity.

In the aftermath of the "Yubari shock", the Act on the Assurance of the Sound Financial Status of Local Governments was passed in 2007. It requires all local authorities to report four indicators of their fiscal position, including the accounts of local public corporations and "third sector" joint public-private organisations. This law helped to enhance the transparency of local government finances and contributed to the improvement in their budget balances (Figure 18).

In 2010, Yubari established a Financial Rebuilding Plan based on the criteria in the new law. The plan eased some of the spending cuts. For example, the salary cut for city officials was reduced from $30 \%$ to $20 \%$ on average, but most of the measures remain. Under the new Plan, Yubari issued 32 billion yen of bonds at a $1.5 \%$ interest rate, with $1.25 \%$ covered by the central and prefectural governments. The debt is to be repaid by FY 2026 (Figure 22).

By FY 2015, Yubari had reimbursed 9.5 billion yen of its debt. However, the burden is large: debt repayment accounted for $40 \%$ of general revenue (funds that the city can choose how to spend) in FY 2016 and the share will rise above 50\% in FY 2017 and remain there through FY 2026. While cutting spending, Yubari is also trying to raise revenue by attracting industry, but it is a difficult challenge. With a high local tax burden and low public services, the population is projected to fall by half over the next decade (Figure 21). The objective is to achieve the fiscal plan, while promoting the well-being of those who remain.

Figure 22. Yubari is paying more than half of its general revenue for debt redemption

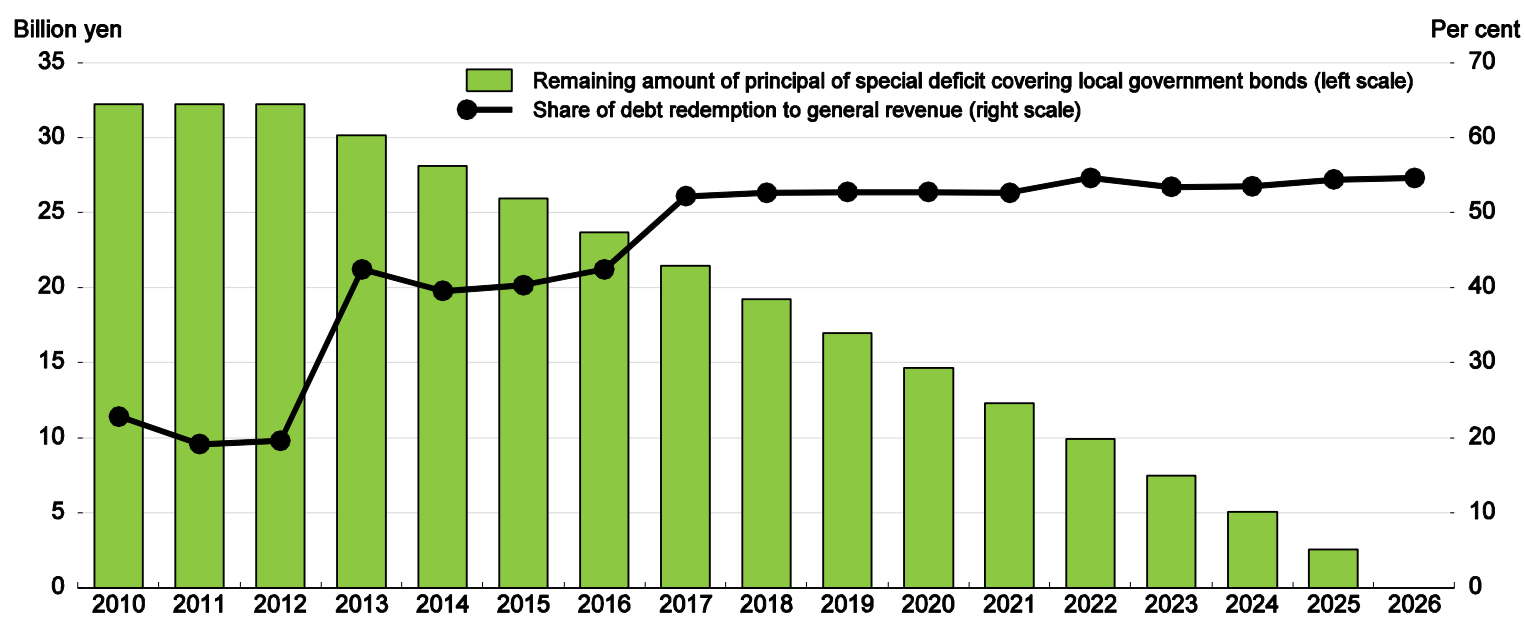

Source: Yubari City (2010); Yubari City (2016); OECD calculations.

Yubari offers important lessons for other towns facing similar challenges. A government research institute estimates that $20 \%$ of municipalities will have a population below 5000 by 2040 (National Institute of Population and Social Security Research, 2013). The government projects that $20 \%$ of residential areas in Japan will become ghost towns by 2050 (MLIT, 2015).

One area where Yubari is setting an example is in the creation of compact cities. Some small communities have merged to reduce public administration costs, but this has led to small governments administering a large area, making it difficult to provide services to remote residents (Mogi and Hagiwara, 2016). Such a solution would be ineffective in Yubari, which has an area of $760 \mathrm{~km}^{2}$ in a mountainous region. Instead, Yubari has consolidated schools, housing and other services in its centre. The most drastic measure has been the relocation of hundreds of residents from public housing on the city's outskirts to new, low-rise apartments close to the city centre. 
Achieving greater fiscal consolidation at the local government level would be facilitated by reforms to enhance the ability of local authorities to innovate and provide services matching local citizens' preferences. Greater local autonomy should be accompanied by greater fiscal discipline in local governments by strengthening fiscal rules, including spending limits, while support to local jurisdictions facing financial troubles should be reduced, so as to limit moral hazard. Financial markets should be allowed to play a more prominent role in disciplining local government behaviour through credit ratings in bond markets. This would require that the central government state clearly that it will not intervene as a lender of last resort to local governments and ensure that adequate information on local governments' outstanding debt and implicit liabilities is readily available. An effective solvency regime is also necessary. The following sections will consider spending areas important to local governments, such as childcare, education, public investment, local public corporations and general administrative expenses.

\section{Childcare spending}

The government is promoting the "dynamic engagement of all citizens", in part by expanding childcare capacity by 0.5 million over FY 2013-17. The wages of childcare personnel are also being increased. Childcare capacity varies widely between prefectures, with shortages observed primarily in urban areas, such as Tokyo and Osaka (Figure 23). For example, childcare capacity per child in Kochi prefecture is more than three time higher than in Saitama prefecture, which is close to Tokyo. Policies to increase capacity and raise wages of childcare workers should thus concentrate on major urban areas.

\section{Figure 23. Childcare capacity is limited in major urban areas}

Capacity in accredited childcare centres relative to the number of children ${ }^{1}$ by prefecture in 2016

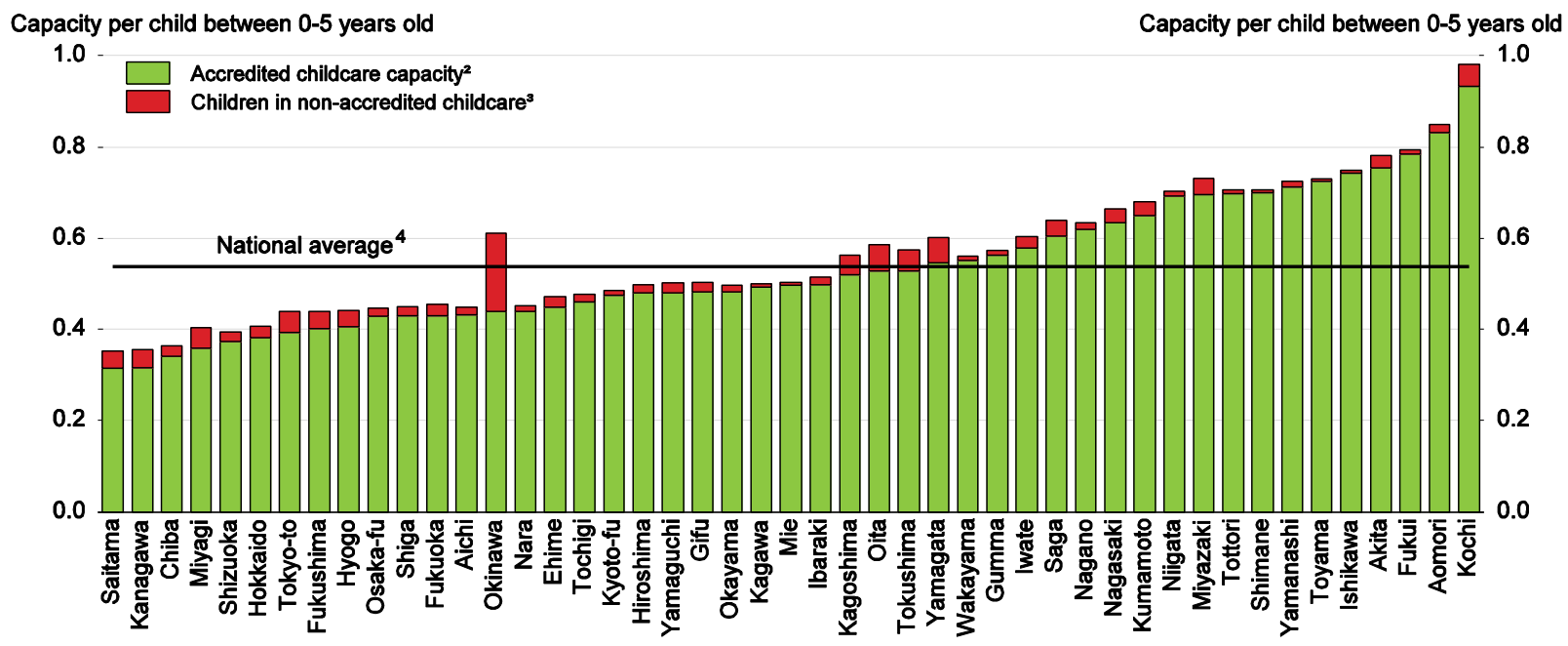

1. Number of children aged 0-5. Number of children aged 5 is calculated as one-fifth of children aged 5-9.

2. Based on the number of accredited childcare facilities and Kodomo-en (combined childcare and kindergartens). The capacity of each Kodomo-en is assumed to be the same in all prefectures.

3. Based on a survey by the Ministry of Health, Labor and Welfare in 2012.

4. Accredited childcare capacity (including Kodomo-en).

Source: Ministry of Health, Labor and Welfare; Cabinet Office; OECD calculations.

The fiscal burden would be eased by expanding the capacity of private childcare. First, entry by corporations is virtually restricted by policies such as a reduced corporate income tax and subsidies for social welfare organisations. Consequently, such organisations are prevalent in providing childcare. Second, quality regulations, such as the minimum area for childcare centres, set by some local governments, exceed national standards. The rationale for more stringent standards, which limit entry by new suppliers, should be reviewed (Yashiro, 2016). Third, measures to cope with childcare personnel shortages are needed, 
including further promoting the return of qualified nursery teachers who are not currently employed in childcare centres. In addition, some workers with experience in related fields, such as kindergarten or nursing, should be allowed to work in childcare even without formal qualifications.

\section{Education spending}

Municipalities are responsible for primary and middle schools and prefectural governments for high schools. With the number of children in primary and middle school falling by around a quarter during the past 20 years, educational costs paid by local governments decreased by $10 \%$ to 16.7 trillion yen in FY 2014. The savings were achieved by declines in the number of schools and classes by $13 \%$ and $11 \%$, respectively, while the number of teachers fell by $6 \%$. Consequently, the number of students per teacher in primary and middle school fell from 19 in 1994 to 15 in 2014, almost matching the OECD average.

The fall in the number of students per teacher was intended in part to improve the quality of education. However, it also reflects disincentives for school consolidation in the LAT, which is based on the number of schools and classes as well as on the number of children. To improve incentives, the LAT added an "adjustment coefficient" that is applied for several years following school consolidation. The cost savings of consolidation, though, are primarily accrued by national and prefectural governments, who pay teacher salaries, rather than by municipalities (Honda, 2012).

By 2030, the school-age population (5-14) will shrink by another quarter (Figure 24). The decline can be used to lower average class size in prefectures where it is still high. However, the largest declines will be in prefectures where class size is already low, creating scope for further reductions in the number of schools and classes. To realise savings, incentives for municipalities to consolidate schools and classes should be enhanced. Indeed, a government study shows positive consequences of maintaining adequate class size on learning (MEXT, 2015).

Figure 24. The fall in the number of school-age children allows scope for school consolidation Number of students per class and the number of school-age children in 2030 as a percentage of the 2015 level $^{1}$
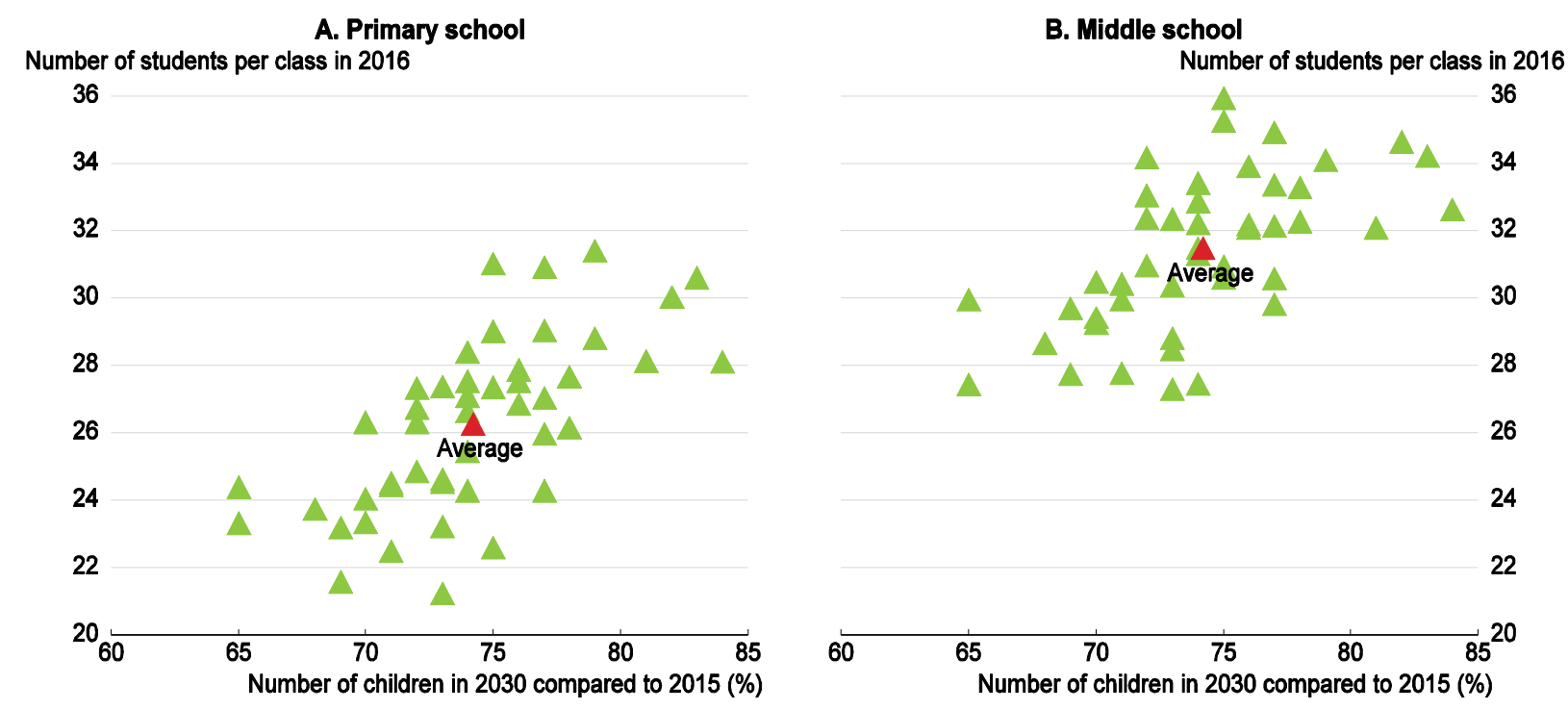

1. Each triangle represents one of Japan's 47 prefectures.

Source: Ministry of Education, Culture, Sports, Science and Technology; National Institute of Population and Social Security Research; OECD calculations. 


\section{Public investment}

Japan's stock of public capital is high, reaching 107\% of GDP in 2013, compared to between 34\% and $65 \%$ in other G7 economies (Figure 25). The high level reflects large-scale public investment during the 1990 s, when fiscal packages focused on public investment were launched nearly every year in an effort to revitalise the economy. For example, the length of express highways increased by around $70 \%$ between FY 1994 and FY 2015, while the population rose by only 1.4\%. The marginal return on additional public investment in Japan is estimated to be negative (Fournier, 2016). Japanese public investment has decreased from 8.9\% of GDP in FY 1994 to 5.0\% in FY 2015, but is still the highest among G7 countries.

\section{Figure 25. The public capital stock in Japan is exceptionally large}

In 2013

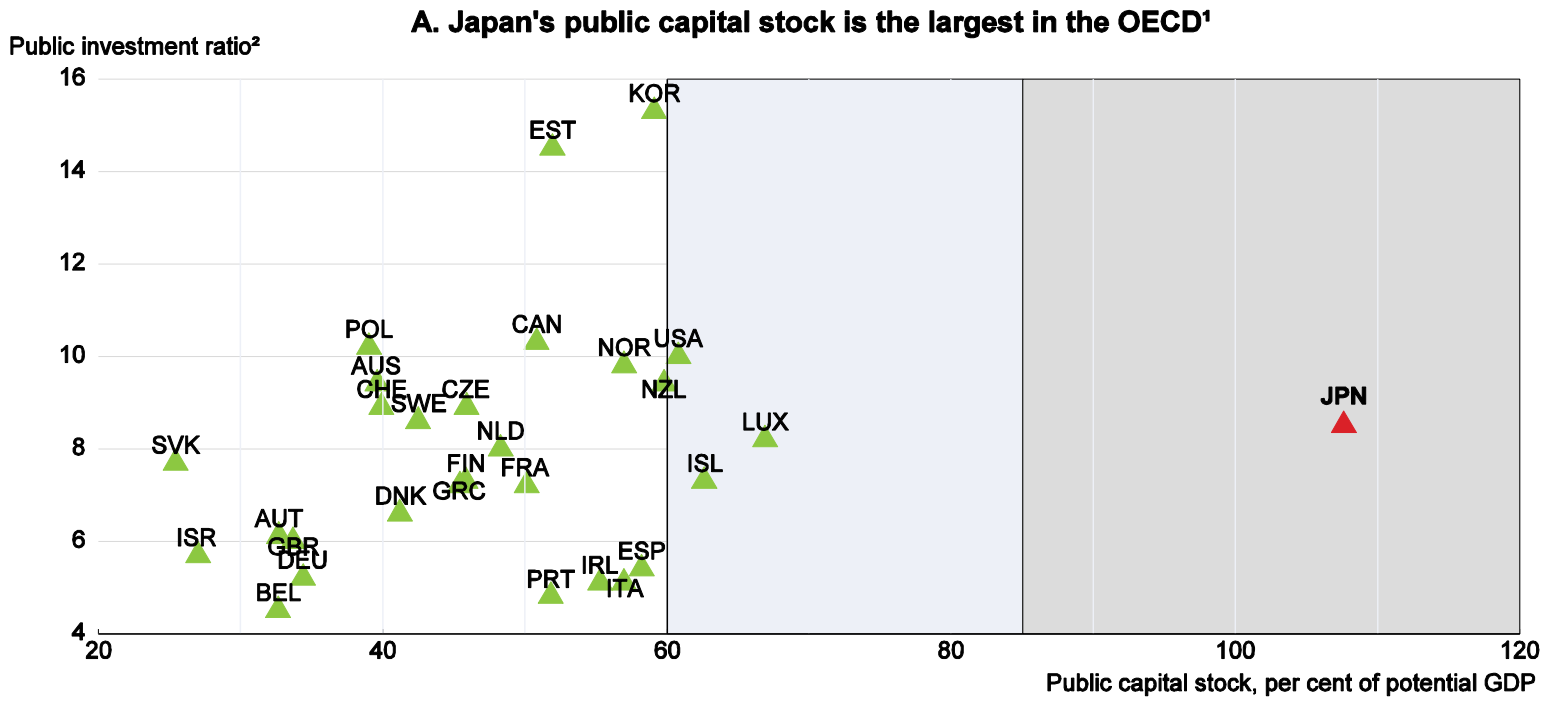

B. The effect of public investment on potential GDP decreases with the level of capital stock ${ }^{3}$

GDP gain of one spending point increase of public investment, \% 15

GDP gain of one spending point increase of public investment, \%

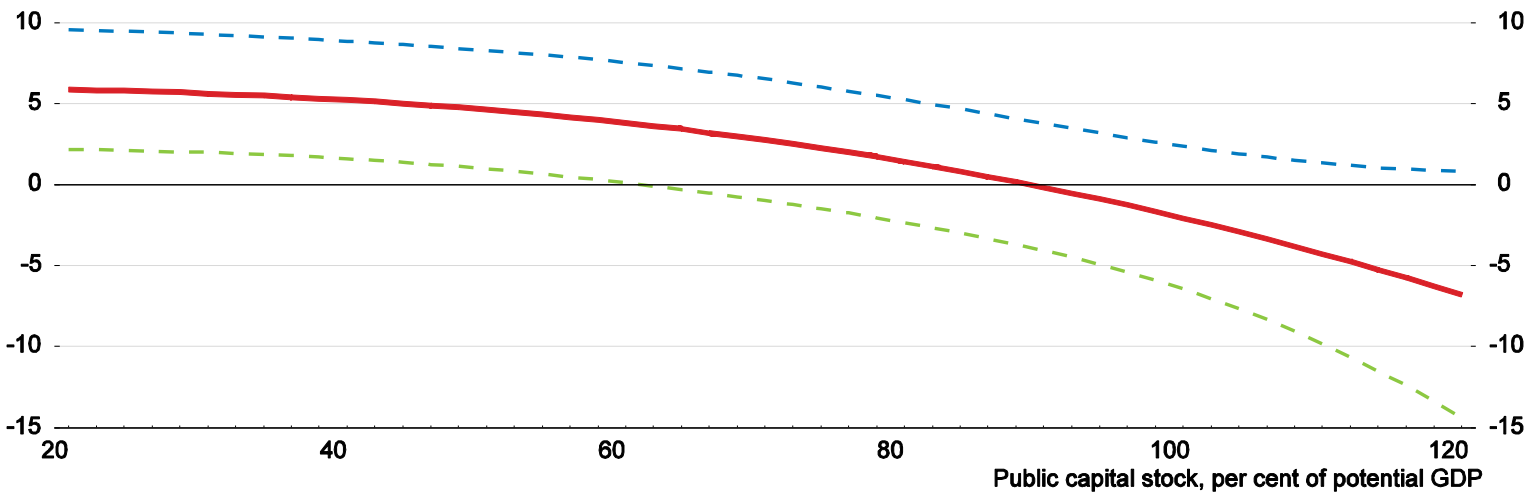

1. The data on the capital stock, which are from the IMF, depend on the rate of capital depreciation. Japanese government estimates range from $77-96 \%$. The light shading indicates a positive but not significant impact from the investment effect and the darker shading indicates a negative, but not significant effect based on the results in Panel B.

2. Public investment as a percentage of underlying public spending.

3. The dashed line indicates the $95 \%$ confidence interval.

Source: Fournier (2016). 
With public investment falling, the average age of public infrastructure is rising (Table 6), which will put upward pressure on local government expenditure for maintenance and replacement, especially in rural areas (Panel B). The government estimates that replacement and maintenance costs for ten types of infrastructure will rise from 3.6 trillion yen (0.7\% of GDP) in FY 2013 to between 4.3 and 5.1 trillion yen in 2023. With the population falling, local governments need to carefully select which infrastructure to keep open to limit maintenance costs, with due regard to the welfare of local residents.

Policies to promote compact cities would bring a number of benefits: $i$ ) greater convenience by improving access to social services, such as health and education; ii) higher productivity in services, for example through increased sales in retail outlets; and iii) lower administrative costs (MLIT, 2015). The government recently launched a National Spatial Strategy to develop compact, networked and diverse cities (OECD, 2016b). This requires more effective land-use regulations and further consolidation of urban functions and residences in designated areas through "location optimization plans" (MLIT, 2016). Such an approach should avoid excessive construction to provide services on a small scale to towns in remote areas and building connective infrastructure to link such areas (OECD, 2016b). To form compact cities, local governments need to co-operate with private entities and neighbouring cities.

In the context of a falling population and the tight fiscal situation, public investment needs to be more focused on projects with the highest returns. The wide regional variation in the marginal productivity of public capital suggests room for improvement. For example, the marginal productivity of transport infrastructure in southern Kanto (which includes Tokyo) is three times higher than in rural areas such as Hokkaido and Shikoku (Cabinet Office, 2014b). Infrastructure should be directed more toward metropolitan areas to boost productivity and support Japan's international competitiveness, and less on reducing regional difference in income (2015 OECD Economic Survey of Japan).

Table 6. The ageing of public infrastructure poses challenges for local governments

\begin{tabular}{|l|c|ccc|}
\hline \multicolumn{1}{|c}{ A. Indicators of infrastructure ageing } \\
& $\begin{array}{c}\text { Local government share } \\
\text { Type of infrastructure }\end{array}$ & Share of assets over 50 years old (\%) & 2033 \\
\hline Roads and bridges (length>2 metres) & 90.0 & 2013 & 2023 & 67 \\
Tunnels & 72.0 & 18 & 43 & 50 \\
River management facilities & 92.6 & 20 & 34 & 64 \\
Sewerages & 100.0 & 25 & 43 & 24 \\
Port quays (water depth $>4.5$ metres) & 100.0 & 8 & 32 & 58 \\
\hline
\end{tabular}

B. Burden of roads, public buildings and sewage facilities by size of municipality ${ }^{1}$

\begin{tabular}{|l|cc|cc|cc|}
\hline $\begin{array}{c}\text { Size of } \\
\text { municipality }\end{array}$ & $\begin{array}{c}\text { Roadway } \\
\text { per capita } \\
\left(\mathrm{m}^{2}\right)\end{array}$ & $\begin{array}{c}\text { Future } \\
\text { replacement } \\
\text { cost }^{2}\end{array}$ & $\begin{array}{c}\text { Public } \\
\text { building } \\
\text { space per } \\
\text { capita }\left(\mathrm{m}^{2}\right)\end{array}$ & $\begin{array}{c}\text { Future } \\
\text { replacement } \\
\text { cost }^{2}\end{array}$ & $\begin{array}{c}\text { Sewage } \\
\text { capacity per } \\
\text { capita } \\
\text { (metres) }^{2}\end{array}$ & $\begin{array}{c}\text { Future } \\
\text { replacement } \\
\text { cost }^{2}\end{array}$ \\
\hline National average & 32.0 & 194.5 & 3.2 & 243.6 & 3.6 & 283.1 \\
Major cities & 21.6 & 73.8 & 3.4 & 201.1 & 2.7 & 215.1 \\
Cities $^{3}$ & 62.4 & 417.2 & 3.6 & 222.3 & 4.1 & 452.8 \\
Towns $^{4}$ & 242.1 & 860.0 & 10.6 & 295.6 & 6.3 & 986.0 \\
\hline
\end{tabular}

1. Estimates are based on a Ministry of Internal Affairs and Communications survey of 111 municipal governments.

2. As a percentage of current expenditure.

3. Population of 50000 to 100000 .

4. Population of less than 10000.

Source: OECD (2016b).

\section{Local public corporations}

Japan had 8662 local public corporations (LPCs) in FY 2014 (not including 7745 LPCs established jointly with private firms). They play an important role in services such as water, public transport and 
hospitals. LPC spending amounts to around one-fifth of local government spending (OECD, 2016b) and is largely financed by fees for services and transfers from local governments, which amounted to 3.1 trillion yen $(0.6 \%$ of GDP) in FY 2014. Without such transfers, LPC losses would have amounted to 2.6 trillion yen. LPCs pose a fiscal threat, as their losses will eventually have to be absorbed by local governments. As population shrinks, LPC fee income will decline, while the ageing infrastructure that they manage will require greater maintenance, further undermining their financial position (Table 6). To maintain scale economies and limit LPC losses, municipalities need to consider a range of options such as consolidation, scaling down and closing existing facilities, expanding LPC business areas and increasing user fees.

The second largest transfer by local governments to LPCs in FY 2014 was 0.8 trillion yen to public hospitals to cover their losses (Cabinet Office, 2016b). The government set guidelines for public hospital reform in 2007 and requested that local governments take measures to enhance efficiency. Over FY 200913, 162 of the 892 public hospitals pursued restructuring and networking, and 227 changed their management structure, including 50 hospitals that transferred business to private entities or downsized (MIAC, 2015). Even so, transfers from local governments to public hospitals did not decline between FY 2007 when the reforms were launched and FY 2014. As the number of beds in public hospitals fell 17\% over that period, transfers per bed rose from 3.0 million yen per year to 3.9 million yen (about 10000 yen or USD 88 per day) (Figure 26). Transfers to small hospitals are almost double those to larger hospitals. Following reforms, the profits of smaller hospitals fell due to a decrease in the number of patients (Cabinet Office, 2016b). Further merger and consolidation of public hospitals would raise efficiency: if half of small public hospitals were consolidated to 400-500 bed hospitals, their profits would increase by 0.23 trillion yen (Ito, 2010).

\section{Figure 26. Government transfers to public hospitals have increased}

Transfers from the government per hospital bed per day

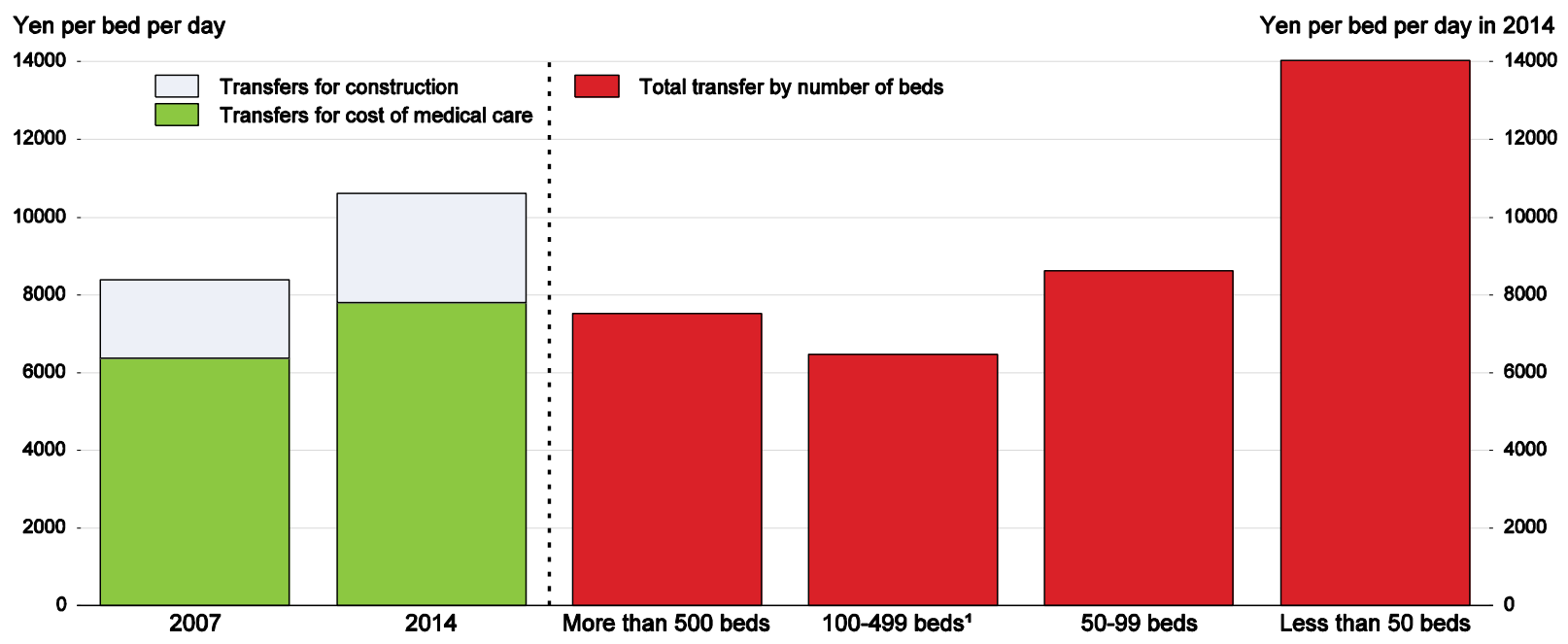

1. Calculated as the simple average of transfers to hospitals with 100-199, 200-299, 300-399, and 400-499 beds.

Source: Ministry of Internal Affairs and Communications.

In 2015, the government updated the reform guideline by clarifying the role of public hospitals, integrating them into the community healthcare initiative, and further promoting restructuring and networking, in part by supporting facility construction. In addition, it will change the basis of calculation of LAT for the operating expenses of public hospitals from the number of beds in a hospital to the number that are occupied, thus enhancing efficiency. Given the exceptionally large number of hospital beds in Japan (Table 4) and its link to longer hospital stays and higher medical costs (Figure 13), the further expansion of the number of hospital beds, public or private, should be avoided. 


\section{Local administrative services}

Enhancing the efficiency of administrative services is essential to control local government spending. Administrative services show strong economies of scale: the average per capita cost in the five prefectures with the smallest populations is twice as high in the five prefectures with the largest, even after adjusting for differences in salary levels (Cabinet Office, 2016e). To reduce such costs, the government launched in FY 2016 the "Top Runner" method, which calculates unit costs based on the levels in local governments that carried out administrative reform for 16 types of tasks, such as collecting garbage and preparing school lunches. Two additional services are to be outsourced in FY 2017. Currently, there is a wide difference by prefecture in outsourcing, with rural areas lagging behind. Further initiatives to enhance efficiency in local administrative services are necessary.

\section{Increasing revenue while promoting inclusive growth}

With the share of elderly projected to reach $33 \%$ of the population by 2035 , keeping Japan's promises to provide health and long-term care and pension benefits requires boosting government revenue from its relatively low level. Taxes and social insurance contributions rose from 30\% of GDP in 2013 to 32\% in 2014 , but remained below the $34 \%$ OECD average. The lower level reflects smaller contributions from taxes on consumption and personal income (Figure 27). In contrast, the shares of social security contributions, corporate income tax and property tax in government revenue are above the OECD average.

Figure 27. Japan's taxes on goods and services, and personal income are relatively low

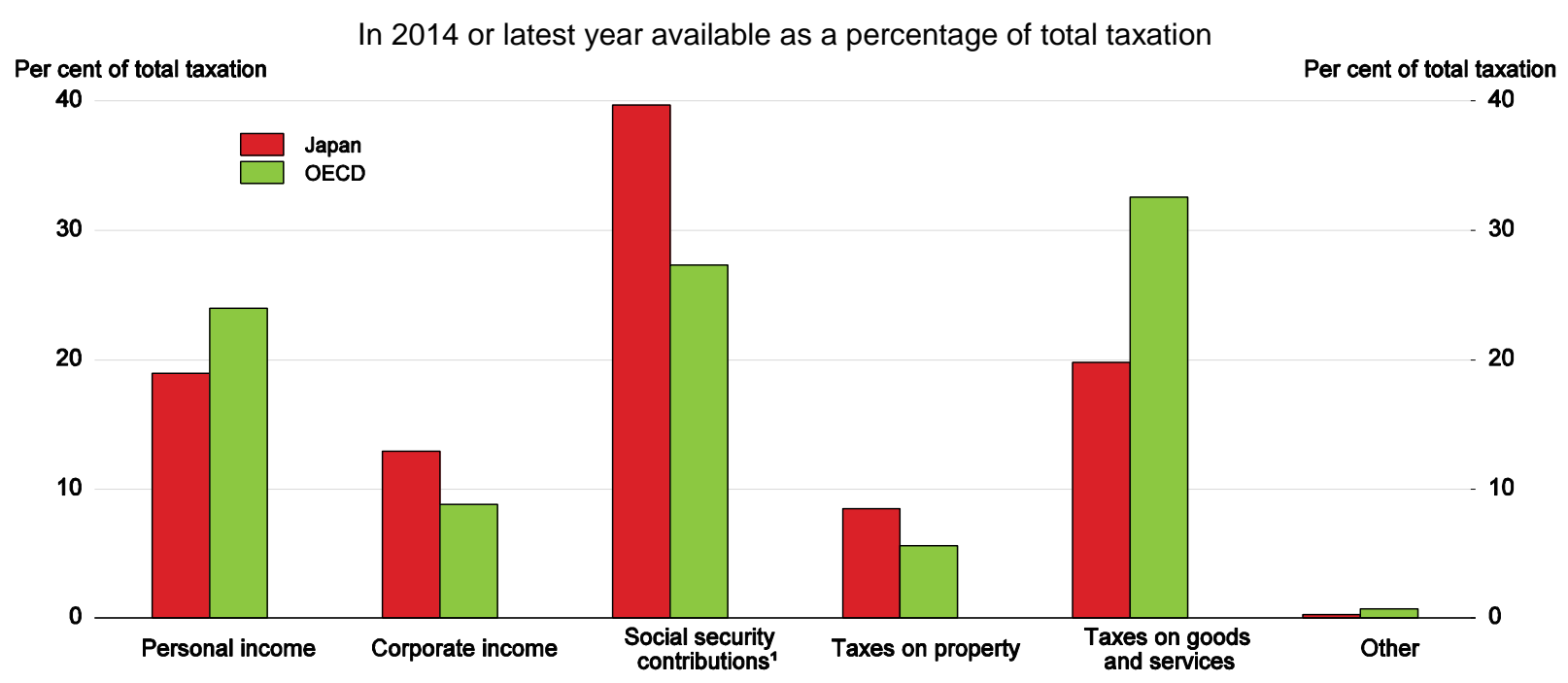

1. Contributions include other payroll taxes.

Source: OECD (2017g), OECD Tax Statistics (database).

Social security contributions as a share of GDP have risen substantially since the early 1990s, in part due to the introduction of long-term care insurance in FY 2000 (Figure 28). In addition, the premiums for health and long-term care insurance and the pension contribution rate have increased steadily. However, this has been offset by a fall in corporate and personal income tax revenues as a share of GDP, reflecting cuts in tax rates. Increases in personal income tax revenue have also been limited by the stagnation in wage income since the early 1990s, and the decline in nominal per capita income. In addition, interest income has dropped to less than one-tenth of its 1991 peak, while capital gains have fallen to around one-fourth. Government revenue should be increased through a comprehensive approach that includes the consumption tax, personal and corporate income tax, social security contributions and the inheritance tax. 
At the same time, inclusive growth should be promoted by expanding the personal income tax base, thereby making it more effective in redistributing income, and introducing an EITC.

\section{Further raise the consumption tax, while keeping a single rate}

A greater role for the consumption tax would improve intergenerational equity, as the elderly would bear more of the tax burden. In addition, the consumption tax is a relatively stable revenue source and is less harmful for economic growth, as it imposes fewer distortions on employment and investment (Arnold et al., 2011). In short, a VAT is the most appropriate tax for raising revenue in Japan. In addition, raising excise duties on alcohol and cigarettes, which also helps enhance health and reduce medical spending, would be a good source of additional tax revenue (OECD Economic Survey of Japan, 2009).

Figure 28. Social security contributions have risen significantly during the past 25 years

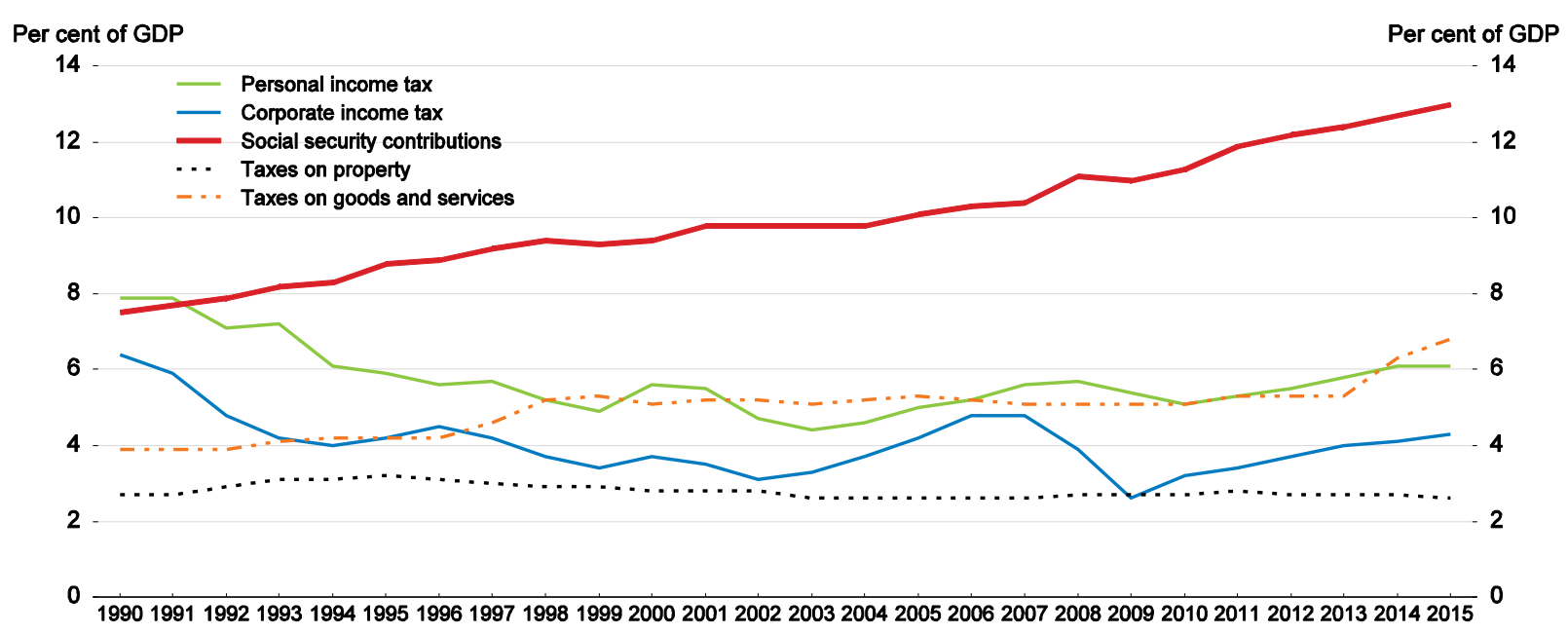

Source: OECD (2017g), OECD Tax Statistics (database).

As noted above, a fiscal consolidation of around $7 \frac{1}{2}$ per cent of GDP is necessary to stabilise the government debt ratio. Achieving this through consumption tax hikes alone would require boosting the rate by 15 percentage points. Consequently, the rate would have to rise from $8 \%$, the second lowest in the OECD, to $23 \%$, close to the European average (Figure 29). Hikes in the consumption tax rate should be achieved through a path of gradual increases to limit the impact on the economy.

Japan's single consumption tax rate has been effective in raising revenue. However, with the planned increase in the rate to $10 \%$ in 2019 , the government intends to introduce multiple rates in an effort to soften the regressive impact. The consumption tax is regressive: it is equivalent to $5.2 \%$ of the income of a typical four-person household with an income below 2 million yen compared to $2.8 \%$ for those earning more than 15 million yen (Figure 29, Panel B). However, multiple tax rates are not effective in mitigating the regressive impact of the consumption tax rate, as most of the benefits go to high-income households (OECD, 2014). An 8\% rate for food and drinks, excluding alcoholic beverages and eating out, would cut the consumption tax payments of households with an annual income of 15 million yen by an average of 24000 yen per year, while the benefit for households with an income of 3 million yen would be only 12000 yen, $0.7 \%$ of their income.

The revenue foregone by introducing a lower rate for food and drinks, excluding alcoholic beverages and eating out, would be better used to finance an EITC, an in-work benefit for low-income earners, as it better targets government assistance on those in need. However, one obstacle to introducing an EITC is concern about the lack of transparency about income, notably among the self-employed. The introduction 
in 2016 of identification numbers ("my number") for taxpayers and social security contributors should enhance income transparency. However, the take-up of the identification cards has been slower than expected, as less than 10 million cards were issued during the year after the introduction of the system. Introducing an EITC would also allow the government to reduce its contribution to the basic pension and the Japan Health Insurance Association-Managed Health Insurance (JHIAHI), thus helping to offset the cost of an EITC. Redistribution through the EITC would be better targeted and would increase transparency about the burden and beneficiaries than government contributions to the basic pension and the JHIAHI (Nishizawa, 2011). 
Figure 29. Japan's consumption tax is relatively low

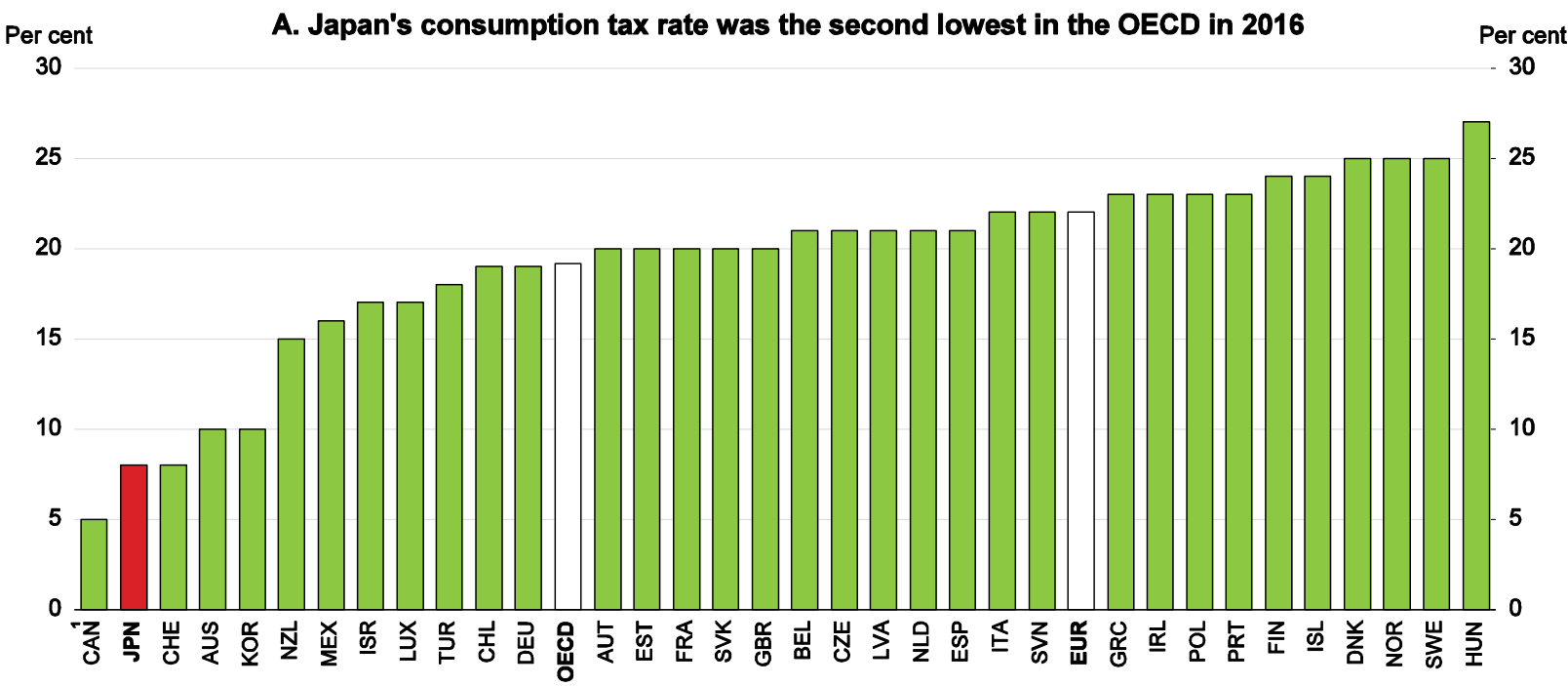

B. The consumption tax is regressive ${ }^{2}$

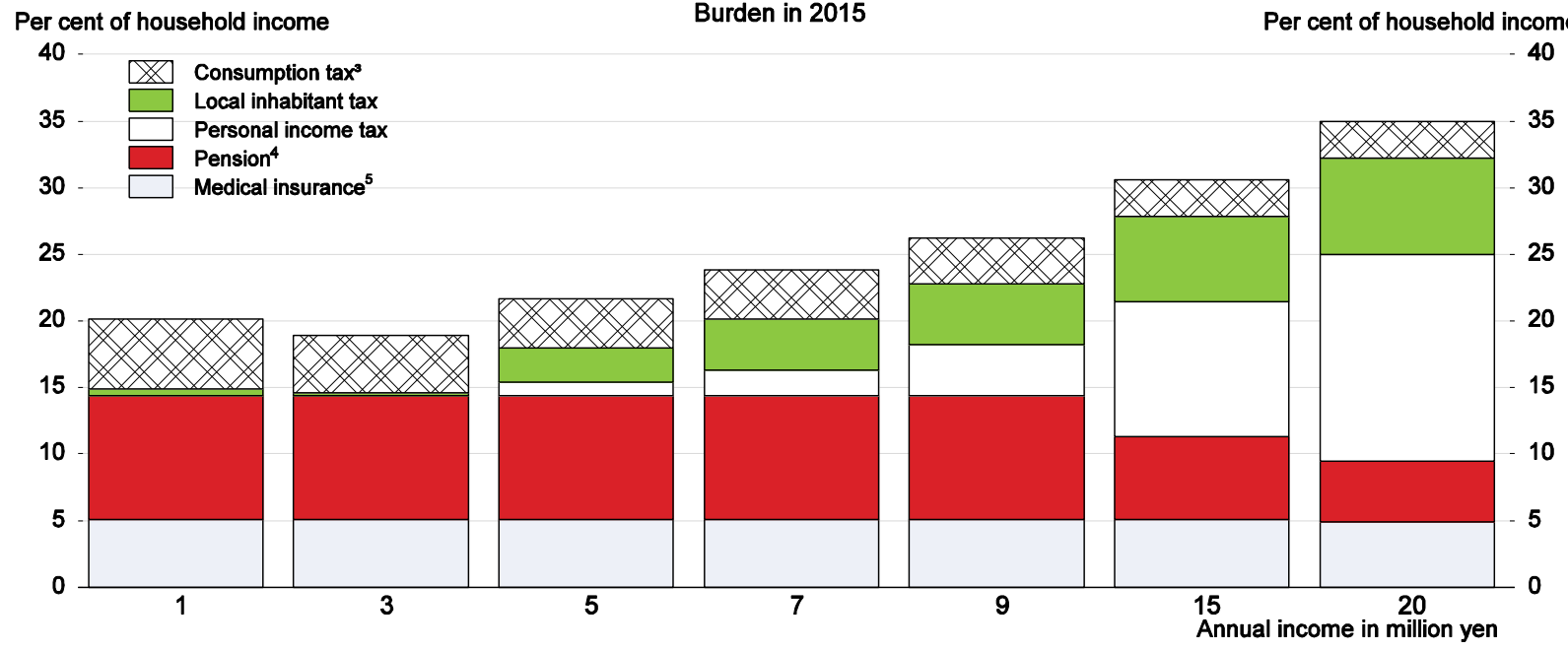

1. In Canada, the provinces can levy a consumption tax on top of the federal tax, making it higher than Japan's $8 \%$.

2. Average households consist of four members; a couple (one earner) with two children, one of whom is between the age of 19 and 23 and the other is between 16 and 18. The calculation assumes that annual bonus payments are equal to four months of salary.

3. The consumption tax burden is based on the consumption spending of four-member households reported in the Family Income and Expenditure Survey, consisting of a couple (one earner) with two children.

4. Pension contributions for the Employees' Pension Insurance.

5. Medical insurance is for the Japan Health Insurance Association-Managed Health Insurance. The long-term care insurance premium is not included.

Source: OECD Consumption Tax Trends 2016; Ministry of Internal Affairs and Communications, The Family Income and Expenditure Survey 2015; OECD calculations.

In addition to failing to promote income equality, a multiple-rate consumption tax limits revenue gains, thus requiring an even higher standard rate. An $8 \%$ rate for food and drinks, excluding alcoholic beverages and eating out, would reduce tax revenue by 1.0 trillion yen $(0.2 \%$ of GDP), requiring a standard rate of $10.4 \%$ to offset it. Introducing multiple VAT rates has additional drawbacks (2013 OECD Economic Survey of Japan). First, it would entail higher administrative and compliance costs, especially for SMEs. Second, it would provide opportunities for fraud through the misclassification of items. Third, it would reduce the neutrality of the VAT, thus distorting consumption decisions and decreasing welfare. 


\section{Reforming personal income tax and social security contributions would promote inclusive growth}

Personal income tax revenue in Japan is low as less than half of personal income is taxable (Table 7). First, the largest deduction is for wages. At 62 trillion yen, it is much larger than the costs faced by employees (such as commuting), as it is intended to equalise the tax burden with the self-employed, who tend to avoid a significant share of their tax liability. Reducing the wage deduction is a key to broadening the personal income tax base. As the income of the self-employed becomes more transparent through the "my number" system, the employment deduction could be reduced to the level of the actual costs faced by employees. Second, the public pension deduction covers nearly half of pension benefits. In Japan, pension contributions and investment earnings are not taxed (an exempt-exempt-tax system), and the taxation of benefits is low. Increasing the taxation of pension benefits would also contribute to inter-generational fairness (Ihori, 2010), and could promote efficiency by reducing the tax burden on the working-age population, thereby encouraging them to work and save.

Table 7. Japan's personal income tax base is subject to a range of deductions Trillion yen based on the FY 2014 budget

\begin{tabular}{|c|c|c|c|c|}
\hline \multicolumn{5}{|c|}{ Deductions $=$ around 140 trillion yen } \\
\hline \multirow{2}{*}{\multicolumn{2}{|c|}{$\begin{array}{l}\text { Deductions for expenses } \\
\text { (about } 80 \text { trillion yen) }\end{array}$}} & \multicolumn{2}{|c|}{$\begin{array}{l}\text { Income deduction } \\
\text { (60 trillion yen) }\end{array}$} & \multirow[b]{3}{*}{$\begin{array}{c}\text { Personal income } \\
\text { tax base } \\
\text { (110 trillion yen) }\end{array}$} \\
\hline & & $\begin{array}{l}\text { Personal exemptions } \\
\text { (30 trillion yen) }\end{array}$ & Other (about 30 trillion yen) & \\
\hline \multirow[t]{2}{*}{ 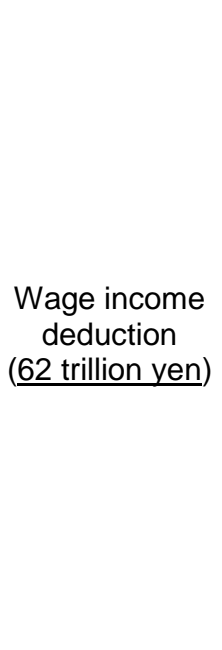 } & \multirow[t]{2}{*}{$\begin{array}{l}\text { Public pension } \\
\text { deduction, etc. } \\
\text { (14 trillion yen) }\end{array}$} & $\begin{array}{c}\begin{array}{c}\text { Basic deduction } \\
(18 \text { trillion yen })\end{array} \\
\text { Spouse deduction } \\
(\underline{5 \text { trillion yen })} \\
\text { General allowance for } \\
\text { dependents } \\
\text { (2 trillion yen }) \\
\text { Special allowance for } \\
\text { dependents }(19-22) \\
\text { (1 trillion yen }) \\
\text { Allowance for elderly } \\
\text { dependents } \\
(1 \text { trillion yen })\end{array}$ & $\begin{array}{l}\text { Exemption for social } \\
\text { insurance premiums } \\
\text { (26 trillion yen }) \\
\text { Exemption for life } \\
\text { insurance premiums } \\
\text { ( } \frac{2 \text { trillion yen })}{\text { Other }} \\
\text { (2 trillion yen })\end{array}$ & \\
\hline & & $\begin{array}{c}\text { Other } \\
(\underline{3 \text { trillion yen }})\end{array}$ & & $\begin{array}{c}\text { Personal income } \\
\text { tax } \\
{\text { (11.7 trillion yen })^{1}}^{11}\end{array}$ \\
\hline
\end{tabular}

1. Tax payments are further reduced by a tax deduction of 0.7 trillion yen for home mortgage payments and dividends.

Source: Ministry of Finance.

Other income deductions further lower taxable income by around 60 trillion yen. One of the most important is the deduction for spouses, which exempts 380000 yen from the main earners' taxable income if the second earner is earning 1.03 million yen or less per year and allows them to be claimed as a dependent by the main earner. However, it reduces the labour supply by encouraging second earners, who are often women, to work part-time and supports the traditional pattern of a primary male earner and lowpaid female second earner. Moreover, most of the benefits of the deduction go to high-income households (2015 OECD Economic Survey of Japan). The government considered a number of options, including 
abolishing the deduction in 2014 and 2016. In the end, it decided to raise the ceiling to 1.5 million yen subject to a limit on the primary earner's income. This will allow second earners to work more without being subject to tax and increase the supply of married non-regular workers. While it is a positive step for increasing the participation of second earners, a more comprehensive approach is needed to enhance the equality between second earners working part-time and those working full-time.

Increasing the share of personal income that is taxed would reduce inequality. Under the current system, the tax wedge, which takes into account tax and social security paid both by workers and employers and the family benefits that workers receive in the form of cash transfers, is significantly higher than the OECD average for low-income families with children and is relatively flat across the income distribution (Jones and Fukawa, 2015). Reducing deductions would raise more tax revenue, some of which could be used to cut the tax burden on low-income households. If the spouse deduction, the basic deduction and allowances for dependents for personal income and local inhabitant tax were abolished and replaced by a tax credit distributed evenly across the income distribution to offset tax and social security contributions, the tax and social security burden of the lowest-income decile would be cut by nearly 10 percentage points (Figure 30). The reduced tax burden on the lower half of the income distribution would be offset by slightly higher burdens for the upper half. Targeting the tax credit on lower-income households would have an even larger impact on income distribution. In addition, phasing out tax deductions for housing loans and dividends would broaden the tax base, while enhancing the redistributive impact of personal income taxes.

\section{Figure 30. Replacing income deductions with a tax credit lowers the burden on low-income households}

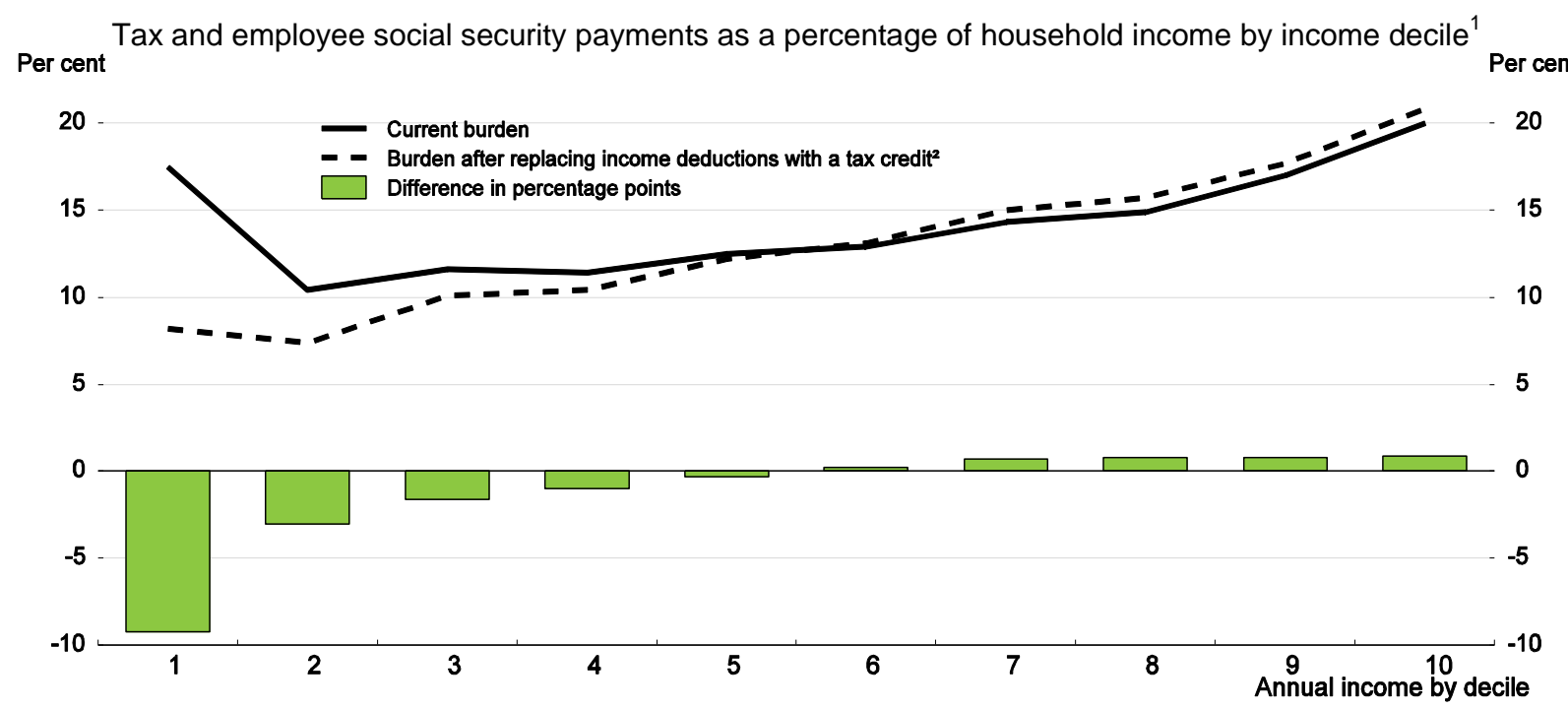

Note: This figure shows the impact of abolishing the spouse deduction, the basic deduction and allowances for dependents for personal income and local inhabitant tax and replacing it by a tax credit distributed evenly across the income distribution.

1. Tax and employee social security payments (personal income and local inhabitant tax and contributions to health, long-term care, pension, and employment insurance) in 2009 are divided by household income, which includes salary and business income as well as income from rent, interest, dividends, public and private pension benefits, livelihood subsidies and childcare allowances. This is based on a household panel survey from 2009.

2. The extra income tax revenue is evenly divided among households as a tax credit (186 000 yen), which is assumed to be used to reduce their social security burden.

Source: Doi and Park (2011); OECD calculations.

A major concern is the regressive nature of social security contributions for non-regular workers, who are not eligible for employee health and pension insurance, and are instead covered by the National Health Insurance (NHI) and the basic pension, which is mandatory. Of the 33 million people covered by the NHI in FY 2014, 34\% were employees and they accounted for 11\% of total employees in Japan (All-Japan Federation of National Health Insurance Organizations, 2016). A four-person household earning 2 million yen per year - less than the poverty line - paid nearly $10 \%$ of their income for health insurance (Figure 31 ). 
In contrast, employees covered by Society-Managed Health Insurance (SMHI) (primarily regular workers in large companies) and JHIAHI (primarily regular workers in small companies) pay only around 3.5\% and $5.0 \%$, respectively, of their income. Adding premiums for the mandatory basic pension makes the burden for non-regular workers earning between 3 and 7 million yen as high as or even higher than for regular workers covered by JHIAHI and the EPI (Panel B). However, the basic pension, which pays only 65000 yen (USD 572) per month after 40 years of contribution, is much smaller than the EPI pension. The share of the population not contributing to the NHI, although it is mandatory, is high for those with low income and for persons under the age of 45 (Panel C), reflecting the substantial burden of the insurance premium. In 2013, around 30\% of persons aged 25 to 34 with an income less than 1 million yen, which is below the poverty line for single households, did not pay the premium.

The best solution would be to expand the coverage of employee-based social insurance to non-regular workers. This would make firms bear the same financial burden for social insurance payments for nonregular workers as for regular workers, thereby reducing the incentive to offer non-regular contracts. If such an approach is not feasible, the government should address the problem by shifting from an income deduction to a tax credit, thus increasing the progressivity of the tax and social contribution systems.

In addition to reducing deductions, taxes on capital income levied at the individual level should be increased to restore the progressivity of the tax system. Indeed, the effective tax rate peaks at $29 \%$ for those with an income between 50 million and 100 million yen per year (USD 44000 to 88000 ) and then falls steadily to $17 \%$ for those with an income over 10 billion yen (Figure 32). The lower burden reflects the fact that high-income earners have more capital income, which is taxed separately at a lower rate than other income. The share of capital gains in total income, which is close to zero for those earning less than 50 million, rises to $79 \%$ for those with an income above 10 billion yen. Raising the tax rate on interest income, dividends and capital gains from $20 \%$ to $25 \%$ would increase tax revenue (Morinobu, 2016). Capital income should continue to be taxed separately to limit tax evasion.

\section{Inheritance taxes}

Inheritance in Japan has traditionally been considered to be compensation for caring for one's parents, but with the introduction of long-term care insurance in 2000, such care is increasingly the responsibility of society as a whole. In 2007 , the government cited "progress in social support for the elderly" as a rationale for expanding the inheritance tax (Tax Committee, 2007). Persons aged 75 or older will have received net social benefits amounting to $16 \%$ of their lifetime income (Figure 8). Even with the expansion of the inheritance tax base in 2015, only $8 \%$ of the deceased are taxed. Further broadening the base would generate revenue and enhance fairness between generations. Some experts go as far as to recommend using the inheritance tax to recover all the excess benefits received by the older generation (Atsumi 2005; Suzuki, 2014). 
Figure 31. Social security contributions pose heavy burdens on non-regular workers In FY $2013^{1}$
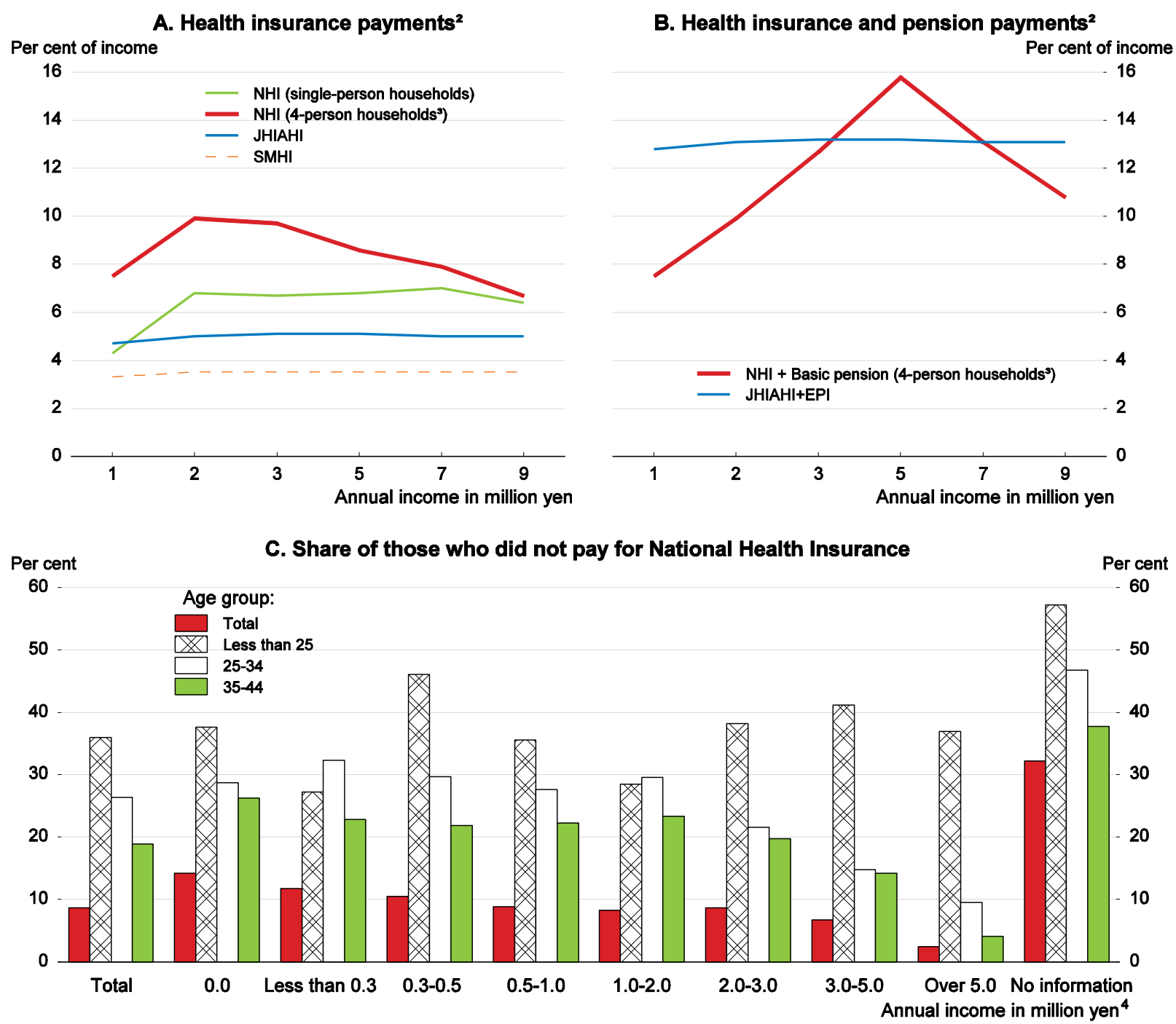

1. The SMHI is mainly for regular workers in large companies, and JHIAHI is mainly for regular workers in small companies. Contributions paid by employers are not included in the figure. National Health Insurance (NHI) is for those who are not covered by employee health insurance schemes (SMHI and JHIAHI).

2. The calculation assumes that annual bonus payments are equal to four months of salary.

3. Average households consist of four members; a couple (one earner) with two children, one of whom is between the age of 19 and 23 and the other is between 16 and 18.

4. Annual household income before basic deductions.

Source: All-Japan Federation of National Health Insurance Organizations (2014); MHLW, National Health Insurance Survey; OECD calculations.

\section{Broadening the corporate income tax base}

Japan reduced its combined (national and local government) corporate income tax rate from $37 \%$ in FY 2013, the second highest in the OECD, to $29.97 \%$ in FY 2016 to promote growth, while broadening the base. This initiative is intended to "raise companies' profitability by spreading the tax burden more widely and reducing the burden on companies with profit-earning power" (Ministry of Finance, 2015). The government intends to lower the rate slightly to $29.74 \%$ in FY 2018, edging it closer to the OECD average of $25 \%$. Given the fiscal situation, broadening the tax base is essential to make corporate tax reform revenue neutral. The priority in this regard is to abolish and limit special tax incentives based on constant reviews of their effectiveness. 
Figure 32. The effective personal income tax rate on high earners is reduced by low rates on capital gains

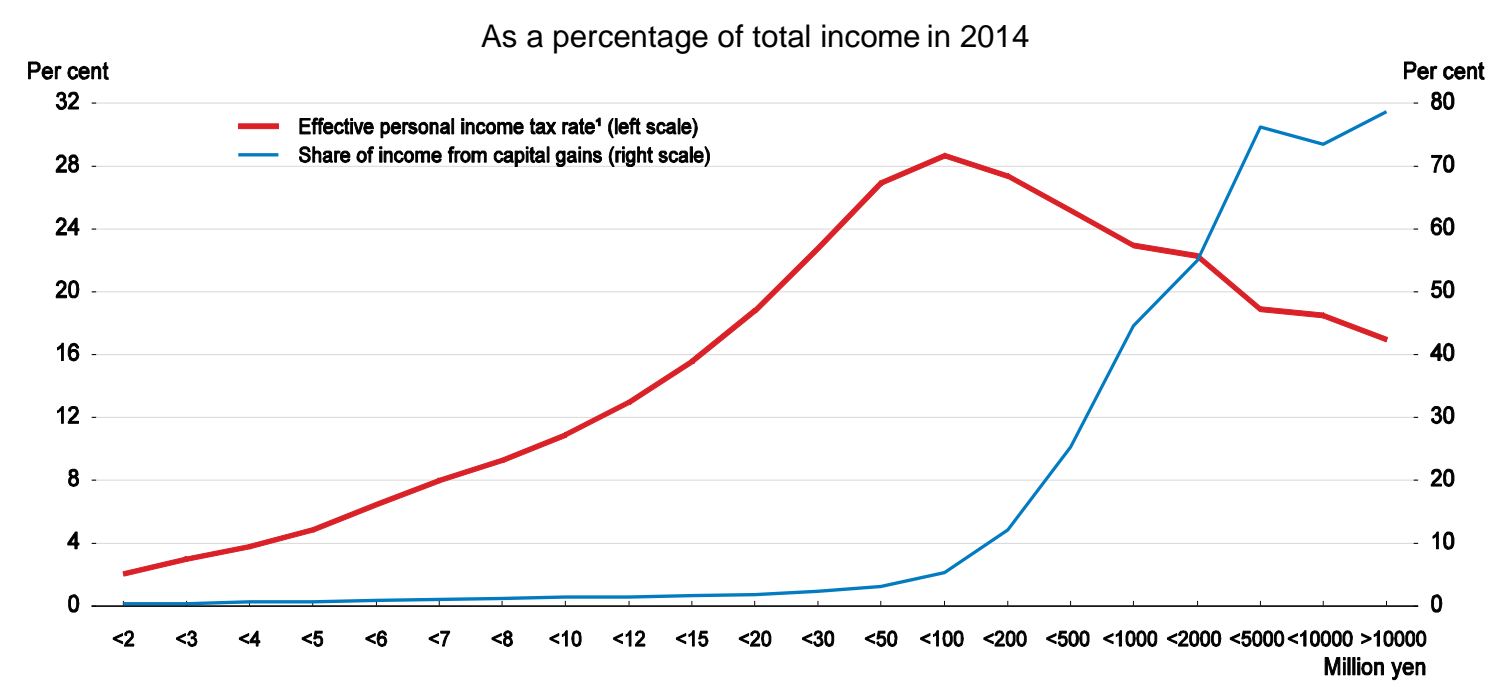

1. Calculated by dividing personal income tax payments by total personal income, including labour and capital income (dividends interest, and rental income). The data cover persons making personal income tax declarations (income taxed at source is not included).

Source: National Tax Agency.

\section{Environmentally-related taxes}

Japan's economy has long been characterised by relatively high energy efficiency and low greenhouse gas (GHG) emissions. However, the closure of the nuclear power plants resulted in a rise in the carbon intensity of Japan's energy mix since 2011. Japan's Intended Nationally Determined Contribution aims to cut the country's emissions by $26 \%$ from 2013 levels by 2030 through a comprehensive approach that promotes energy efficiency and uses low-carbon energy sources, such as nuclear and renewable energy. Raising environmentally-related taxes would also boost revenue while helping to reduce GHG emissions and achieve other environmental objectives, such as improving air quality (2013 OECD Economic Survey of Japan). Japan has taken steps in this regard, notably by introducing the Tax for Climate Change Mitigation, which increased an existing tax on petroleum and coal in three steps in 2012, 2014 and 2016, with the revenues earmarked for renewable energy and energy conservation. However, in 2014, environmentally-related taxes were only $1.5 \%$ of GDP, the sixth lowest in the OECD and well below the mean (Figure 33), suggesting scope for raising revenue.

Figure 33. Environmentally-related taxes in Japan are well below the OECD mean

Percentage of GDP in 2014

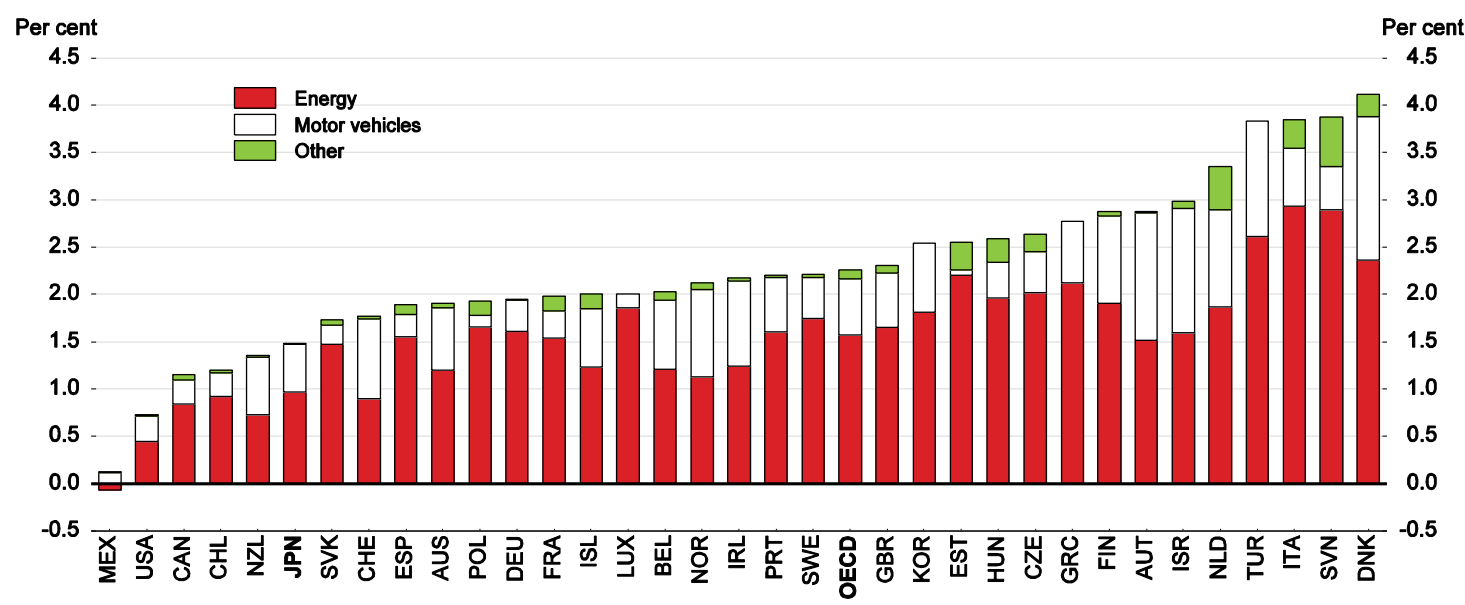

Source: OECD (2016d). 
ECO/WKP(2017)45

Box 4. Main policy recommendations to ensure fiscal sustainability in the context of a shrinking and ageing population

\section{Key recommendations}

- Commit to a more detailed medium-term fiscal consolidation path with specific spending cuts and tax increases to strengthen confidence in Japan's fiscal sustainability.

- $\quad$ Gradually raise the consumption tax rate.

- Enhance equity by introducing an earned income tax credit.

- $\quad$ Fully apply macroeconomic indexation as soon as possible.

- $\quad$ Raise the pension eligibility age above 65.

- Take long-term care out of hospitals and reduce long-term care insurance coverage for those with less severe needs.

- Increase the use of generics.

\section{Other recommendations}

- Improve the fiscal framework.

- Scale back transfers from the working-age population to the elderly by raising co-payments and the ceilings on total co-payments for the elderly for health and long-term care, while taking account of equity implications.

- $\quad$ Expand the coverage of the Basic Livelihood Protection Program, while reforming it to encourage work.

- Require local governments to pursue fiscal consolidation in tandem with the central government by reducing transfers from central to local governments and imposing spending rules.

- Enhance incentives for school consolidation to adjust to the falling number of children.

- $\quad$ Focus increases in childcare capacity on urban areas facing shortages, in part by facilitating greater entry by private firms.

- $\quad$ Lower public investment by carefully reducing public infrastructure in line with demographic changes and concentrating new investment on projects with the highest returns.

- Maintain the financial viability of local public corporations through consolidation, expansion of business areas and increased user fees.

- Raise taxes on capital income to increase the effective tax rate on high-income earners.

- Increase the coverage of firm-based social insurance and ensure better compliance with the public pension schemes. 


\section{REFERENCES}

All-Japan Federation of National Health Insurance Organizations (2014), Seeking Stability of the National Health Insurance: Health Insurance Reform, All-Japan Federation of National Health Insurance Organizations, Tokyo (in Japanese).

All-Japan Federation of National Health Insurance Organizations (2016), Seeking Stability of the National Health Insurance: Health Insurance Reform, All-Japan Federation of National Health Insurance Organizations, Tokyo (in Japanese).

Arnold, J., B. Brys, C. Heady, A. Johansson, C. Schwellnus and L. Vartia (2011), "Tax Policy for Economic Recovery and Growth", Economic Journal, Vol. 121.

Atsumi, N. (2005), "Direction of Inheritance Tax Reform as Social Security Revenue Source: Simulations for Strengthened Inheritance Tax Case and New Tax Case", Economic Review, Vol. 9, No. 2, Fujitsu Research Institute, Tokyo (in Japanese).

Bertelsmann Siftung (2013), Intergenerational Justice in Aging Societies A Cross-national Comparison of 29 OECD Countries, Gütersloh, Germany.

Cabinet Office (2014a), Annual Report on the Aging Society: 2014, Government of Japan, Tokyo (in Japanese).

Cabinet Office (2014b), Annual Report on the Japanese Economy and Public Finance 2014, Government of Japan, Tokyo (in Japanese).

Cabinet Office (2016a), “Comparison of Local Expenditure Per Capita by Prefecture”, Document 5 in Committee on Promotion of Integrated Reform on Economic and Fiscal Issues, 23 September, Government of Japan, Tokyo.

Cabinet Office (2016b), "Economic and Fiscal Impacts of Public Hospital Reform: Analysis Using Individual Hospital Data of 'Public Local Enterprise Yearbook'”, Policy Analysis Series, No. 10, Government of Japan, Tokyo (in Japanese).

Cabinet Office (2016c), Economic and Fiscal Projections for Medium to Long-term Analysis, 26 July, Government of Japan, Tokyo (in Japanese).

Cabinet Office (2016d), "8th International Comparative Poll on the Elderly's Life and Consciousness Survey, 2015”, Government of Japan, Tokyo (in Japanese).

Cabinet Office (2016e), Regional Economy 2016 - To Overcome Population Decline Problems, Government of Japan, Tokyo (in Japanese).

Cabinet Office (2017), Economic and Fiscal Projections for Medium to Long-term Analysis (January) Government of Japan, Tokyo (in Japanese).

Doi, T. and S. Park (2011), "Micro-simulation of the FY 2011 Package of Tax Revisions", Keio/Kyoto Global COE Discussion Paper Series, DP2011-001 (in Japanese).

European Commission (2012), "The 2012 Ageing Report: Economic and Budgetary Projections for the 27 EU Member States (2010-2060)", European Economy Series 2/2012, Brussels, http://ec.europa.eu/economy_finance/publications/european_economy/2012/pdf/ee-2012-2_en.pdf. 
European Commission (2015), "The 2015 Ageing Report: Economic and Budgetary Projections for the 28 EU Member States (2013-2060)", European Economy Series 3/2015, Brussels, http://www.cnfp.lu/fr/publications/com-ageingreport2015/ageing-report-2015.pdf.

Expert Members of the Council on Economic and Fiscal Policy (2016), "To Realize Fiscal Consolidation Targets in FY 2020", Document 2 in Council on Economic and Fiscal Policy, 26 July, Government of Japan, Tokyo (in Japanese).

Fiscal System Council (2015), Long-term Estimations of Japanese Finance (Revised Version), Document 1, 9 October, Tokyo (in Japanese).

Fournier, J.-M. (2016), "The Positive Effect of Public Investment on Potential Growth", OECD Economics Department Working Papers, No. 1347, OECD Publishing, Paris.

Geji, K. (2016), "Deep Pessimism in Japan about Future and State of Democracy", Asahi Shimbun, 27 August.

Hamada, K. (2003), "Distribution Statistics of SNA Household Accounts - National Accounts Based Income and Asset Distribution", Economic Analysis, No. 167, Economic and Social Research Institute, Tokyo (in Japanese).

Hamada, K. (2012), "Estimation of SNA Distribution Statistics for 2009: National Accounts Based Income and Asset Distribution in the Latter Half of the 2000s", Quarterly National Account, No. 148, Economic and Social Research Institute, Tokyo (in Japanese).

Hamada, K. et al. (2015), "Structure of the Japanese Short-term Macro Model (2015 version) and Fiscal Multipliers", ESRI Discussion Paper Series, No.314, Economic and Social Research Institute, Tokyo (in Japanese).

Hida, E. (2015), "Issues to Contain Long-term Care Expenses - Analysis Based on Insurance Data", JRI Review, No. 30, Japan Research Institute, Tokyo (in Japanese).

Honda, M. (2012), "Financial Management of Local Governments, School Sizes and School Facilities Location", Bulluetin of National Institute for Educational Policy Research, No.141, National Institute for Educational Policy Research, Tokyo (in Japanese).

Horrocks, S., E. Anderson and C. Salisbury (2002), "Systematic Review of Whether Nurse Practitioners Working in Primary Care Can Provide Equivalent Care to Doctors", British Medical Journal, No. 324 (7341).

Ihori, T. (2010), "Overall Picture of Tax Reforms", in How the Japanese Tax System Should be Reformed, edited by T. Doi, Nihon Keizai Shinbunsya (in Japanese).

Ii, M. and M. Sekimoto (2014), "Characteristics and Problems of Japan's Primary Care System”, Financial Review, Vol. 123, Ministry of Finance, Tokyo (in Japanese).

Ito, Y. (2010), "Agglomeration of Medical Services in Towns; Why the Accumulation of Medical Resources Can be a Strategy", Chapter 3 in Recommendation on the Agglomeration of Medical Service in Towns, edited by T. Komine, NIRA, Tokyo (in Japanese).

International Monetary Fund (2009), Fiscal Rules - Anchoring Expectations for Sustainable Public Finance, Washington, DC.

Jones, R. (2009), "Health-Care Reform in Japan: Controlling Costs, Improving Quality and Ensuring Equity”, OECD Economics Department Working Papers, No. 739, OECD Publishing, Paris.

Jones, R. and K. Fukawa (2015), "Achieving Fiscal Consolidation while Promoting Social Cohesion in Japan”, OECD Economics Department Working Papers, No. 1262, OECD Publishing, Paris, http://dx.doi.org/10.1787/5jrtpbs9fg0v-en. 
Jones, R. and Y. Jin (2017), "Boosting Productivity for Inclusive Growth in Japan", OECD Economics Department Working Papers (forthcoming), OECD Publishing, Paris.

Kato, T. (2016), "Financial Rebuilding of Local Governments: Efforts for Yubari City”, House of Councillors Secretariat, Vol. 375, pp 59-70, Tokyo (in Japanese), http://www.sangiin.go.jp/japanese/annai/chousa/rippou_chousa/backnumber/2016pdf/20160307059 .$p d f$.

Maeda, S. and M. Umeda (2013), "Re-estimation of Consumption and Savings in SNA Distribution Statistics", Quarterly National Account, No. 150, Economic and Social Research Institute, Tokyo (in Japanese).

Maeda, Y. (2015), "For Better Understanding of Regional Medical Care", Japan Medical Association Research Institute Working Papers, No. 341, Japan Medical Association Research Institute, Tokyo (in Japanese).

Manpower Group (2016), Millennial Careers: 2020 Vision Facts, Figures and Practical Advice from Workforce Experts,http://www.manpowergroup.com/wps/wcm/connect/660ebf65-144c-489e-975c9f838294c237/MillennialsPaper1_2020Vision_lo.pdf?MOD=AJPERES.

Ministry of Education, Culture, Sports, Science and Technology (2015), "Survey of the Actual Situation in Fulfilling School Education with the Under-optimization of School Scale and a Declining Birth Rate", Document 2-3 in the sub-committee on elementary and junior high school education under the Central Education Council, 19 January, Tokyo (in Japanese).

Ministry of Finance (2015), Outline of FY 2015 Tax Reform, Tokyo.

Ministry of Finance (2016), Materials on Japan's Public Finance Situation, Tokyo (in Japanese).

Ministry of Health, Labor and Welfare (2012), Projections on Social Security Benefits and Contributions, Tokyo.

Ministry of Health, Labor and Welfare (2013), Outline of 2011 Health Behavior Survey, Tokyo (in Japanese).

Ministry of Health, Labor and Welfare (2014), Summaries of the 2014 Actuarial Valuation and Reform Options, Tokyo, http://www.mhlw.go.jp/file/06-Seisakujouhou-12500000enkinkyoku/2014_Actuarial_Valuation_3.pdf.

Ministry of Internal Affairs and Communications (2015), "Progress on Public Hospital Reform", Document 7-1 of explanatory meeting for local governments on local public enterprises, 16 October, Tokyo (in Japanese).

Ministry of Internal Affairs and Communications (2016), "Collection of Advanced Cases for Sewage Business", attached document 2-1 of notification to municipal governments issued on 26 January, Tokyo (in Japanese).

Ministry of Land, Infrastructure, Transport and Tourism (2014), Grand Design of National Spatial Development Towards 2050: Creation of a Country Generating Diverse Synergies Among Regions, Tokyo (in Japanese).

Ministry of Land, Infrastructure, Transport and Tourism (2015), Annual Report on Land, Infrastructure, Transport and Tourism in Japan, 2015, Tokyo (in Japanese).

Ministry of Land, Infrastructure, Transport and Tourism (2016), Annual Report on Land, Infrastructure, Transport and Tourism in Japan, 2016, Tokyo (in Japanese). 
Mogi, C. and Y. Hagiwara (2016), "Bankrupt Mining Town Downsizes to Avoid Becoming a Ghost Town", Bloomberg (25 September), http://www.bloomberg.com/news/articles/2016-09-25/bankruptmining-town-downsizes-to-avoid-becoming-a-ghost.

Morinobu, S. (2016), "Strengthening Taxation on Financial Income and Dual Income Tax," Chapter 3 in "Report for Grand Design of Tax and Social Security System," edited by S., Morinobu, Tokyo Foundation, Tokyo (in Japanese).

Nakajima, K. (2016), "Not Changing the Public Pension Benefit is a Double Headache for Pension Finance: Recap of the Annual Revision Rule and the Impact on Pension Finance", Kisoken Report, 2016-02-22, NLI Research Institute, Tokyo (in Japanese).

National Institute of Population and Social Security Research (2013), Forecasts of Japan's Population by Region 2013, Tokyo (in Japanese).

National Institute of Population and Social Security Research (2016), Financial Statistics of Social Security in Japan 2013, Tokyo (in Japanese).

Nishizawa, K. (2011), Comprehensive Reform of Tax and Social Security, Nihon Keizai Shimbun Printing, Tokyo.

OECD (2012), Draft Principles for Independent Fiscal Institutions, OECD Publishing, Paris.

OECD (2013), OECD Economic Survey of Japan, OECD Publishing, Paris.

OECD (2014), "The Distributional Effects of Consumption Taxes in OECD Countries", OECD Tax Policy Studies, No. 22, OECD Publishing, Paris.

OECD (2015a), Historical Population Data and Projections (1950-2050), OECD Publishing, Paris.

OECD (2015b), OECD Economic Survey of Japan, OECD Publishing, Paris.

OECD (2015c), OECD Regional Statistics 2015, OECD Publishing, Paris.

OECD (2016a), Annual Survey of Large Pension Funds and Public Pension Reserve Funds 2015, OECD Publishing, Paris.

OECD (2016b), OECD Territorial Reviews: Japan 2016, OECD Publishing, Paris.

OECD (2016c), Subnational Governments in OECD Countries: Key Data, OECD Publishing, Paris.

OECD (2016d), Taxing Energy Use: A Graphical Analysis, OECD Publishing, Paris.

OECD (2017a), Investing in Youth: Japan, OECD Publishing, Paris.

OECD (2017b), OECD Economic Outlook: Statistics and Projections (database), OECD, Paris.

OECD (2017c), OECD Economic Survey of Japan, OECD Publishing, Paris.

OECD (2017d), OECD Health Statistics (database), OECD, Paris.

OECD (2017e), OECD Income Distribution (database), OECD, Paris.

OECD (2017f), OECD Social Expenditure Statistics (database), OECD, Paris.

OECD (2017g), OECD Tax Statistics (database), OECD, Paris.

Oshio, T. (2013), Economics of Social Security, Nippon Hyoron Sha, Tokyo (in Japanese).

Seaton, P. (2010) "Depopulation and Financial Collapse in Yubari: Market Forces, Administrative Folly, or a Warning to Others?" Social Science Japan Journal, Vol. 13, No. 2.

Shigeoka, H. (2014), "The Effect of Patient Cost Sharing on Utilization, Health and Risk Protection", American Economic Review, Vol. 104, No.7. 
Suzuki, W. (2014), An Argument that Japan Will Be Destroyed by Social Security, Kodansha, Tokyo (in Japanese).

Tajika, E. and Y. Yui (2004) "Long-Term Care Insurance: What Has Been Learned from Four Years of Experience," Financial Review, Vol. 72, Ministry of Finance, Tokyo (in Japanese).

Tajika, E. and J. Kikuchi (2006) "What are the Problems of Long-term Care Insurance? The Process of Establishing the Institution and Examining the Impact of Improving Long-term Care Conditions," Financial Review, Vol. 80, Ministry of Finance, Tokyo (in Japanese).

Tax Committee (2007), Basic Approach to Fundamental Tax Reform, Tokyo, (in Japanese), http://www.cao.go.jp/zeicho/tosin/pdf/191120a.pdf.

Tsujido, T. (2010), "The Trajectory of the Fiscal Collapse in Yubari City and the Issues for Reconstruction", Jichi Souken, Vol. 384, (in Japanese), http://jichisoken.jp/publication/monthly/JILGO/2010/10/mtsujimichi1010.pdf.

Tsutsui, T., S. Higashino, M. Nishikawa and M. Otaga (2015), "Medical and Long-term Care Services Provided to Hospitalized Patients in Japan: Data Analysis from a 2012 National Survey", Review of Administration and Informatics, Vol.27, No. 2, University of Shizuoka.

Yamada, T. (2002), "Consideration of Doctor-induced Demand Hypothesis using National Health Insurance Payment Data", Research on Social Security Quarterly, Vol. 38, No.1, National Institute of Population and Social Security Research, Tokyo (in Japanese).

Yashiro, N. (2016), "Regulatory Coherence: The Case of Japan", in D. Gill and P. Intal, Jr. (eds.), The Development of Regulatory Management Systems in East Asia: Country Studies, ERIA Research Project Report 2015-4, Jakarta, ERIA.

Yoneda, Y., S. Sakai, and M. Nakazawa (2015), "Estimation of the Effects of Lowering the Contribution Rate of National Pension on Basic Livelihood Program Expenses", KIER Discussion Paper Series, No. 1508, Kyoto Institute of Economic Research, Kyoto (in Japanese).

Yubari City (2010), "Financial Rebuilding Plan" (in Japanese), http://www.city.yubari.lg.jp/contents/municipal/zaisei/keikaku/documents/1267490600.pdf.

Yubari City (2016), "Financial Rebuilding Plan (after the $5^{\text {th }}$ revision in FY 2016)" (in Japanese), http://www.city.yubari.lg.jp/contents/municipal/zaisei/keikaku/documents/1480383393.pdf.

Yuda, M. (2005), "Effects of Long-term Care Providers' Density on Long-term Care Service Demand", Social Security Research Quarterly, Vol. 167, National Institute of Population and Social Security Research, Tokyo (in Japanese).

Yuda, M. (2013), "Changes in Medical Supply Densities, and Supplier-induced Demand: Empirical Evidence from Japan”, Hitotsubashi Journal of Economics, Vol. 54. 